\title{
The Sedimentary Carbonate-Hosted Giant Bayan Obo REE-Fe-Nb Ore Deposit of Inner Mongolia, China: A Cornerstone Example for Giant Polymetallic Ore Deposits of Hydrothermal Origin
}

\section{U.S. GEOLOGICAL SURVEY BULLETIN 2143}

The work in this report was made possible by the U.S./People's Republic of China Earth Sciences Protocol between the Academy of Geological Sciences of the Ministry of Geology and Mineral Resources of China and the U.S. Geological Survey, Department of the Interior of the United States of America

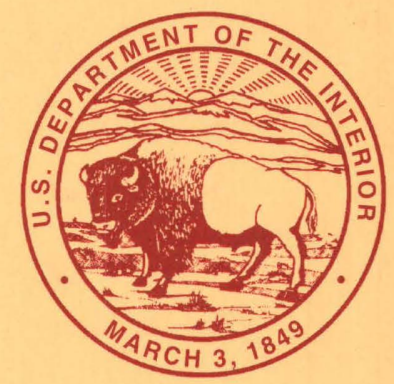


Order U.S. Geological Survey (USGS) publications from the offices listed below. Detailed ordering instructions, along with prices of the last offerings, are given in the current-year issues of the catalog "New Publications of the U.S. Geological Survey."

\section{BOOKS, MAPS, AND OTHER PUBLICATIONS}

\section{By Mail} from-

Books, maps, and other publications are available by mail

\section{USGS Information Services \\ Box 25286, Federal Center, Denver, CO 80225}

Publications include Professional Papers, Bulletins, Water-Supply Papers, Techniques of Water-Resources Investigations, Circulars, Fact Sheets, publications of general interest, single copies of permanent USGS catalogs, and topographic and thematic maps.

\section{Over the Counter}

Books, maps, and other publications of the U.S. Geological Survey are available over the counter at the following USGS Earth Science Information Centers (ESIC's), all of which are authorized agents of the Superintendent of Documents:

- Anchorage, Alaska-Rm. 101, 4230 University Dr.

- Denver, Colorado-Bldg. 810, Federal Center

- Menlo Park, California-Rm. 3128, Bldg. 3, 345 Middlefield Rd.

- Reston, Virginia-Rm. 1C402, USGS National Center, 12201 Sunrise Valley Dr.

- Salt Lake City, Utah-2222 West, 2300 South

- Spokane, Washington-Rm. 135, U.S. Post Office Building, 904 West Riverside Ave.

- Washington, D.C.-Rm. 2650, Main Interior Bldg., 18th and C Sts., NW.

Maps only may be purchased over the counter at the following USGS office:

- Rolla, Missouri-1400 Independence Rd.

\section{Electronically}

Some USGS publications, including the catalog "New Publications of the U.S. Geological Survey" are also available electronically on the USGS's World Wide Web home page at

$$
\text { http://www.usgs.gov }
$$

\section{PRELIMINARY DETERMINATION OF EPICENTERS}

Subscriptions to the periodical "Preliminary Determination of Epicenters" can be obtained only from the Superintendent of
Documents. Check or money order must be payable to the Superintendent of Documents. Order by mail from-

\section{Superintendent of Documents \\ Government Printing Office Washington, DC 20402}

\section{INFORMATION PERIODICALS}

Many Information Periodicals products are available through the systems or formats listed below:

Printed products: Printed copies of the Minerals Yearbook and the Mineral Commodities Summaries can be ordered from the Superintendent of Documents, Government Printing Office (address above). Printed copies of Metal Industry Indicators and Mineral Industry Surveys can be ordered from the Center for Disease Control and Prevention, National Institute for Occupational Safety and Health, Pittsburgh Research Center, P.O. Box 18070, Pittsburgh, PA 15236-0070.

Mines FaxBack: Return fax service.

1. Use the touch-tone handset attached to your fax machine's telephone jack. (ISDN [digital] telephones cannot be used with fax machines.)

2. Dial (703) 648-4999.

3. Listen to the menu options and punch in the number of your selection, using the touch-tone telephone.

4. After completing your selection, press the start button on your fax machine.

Mines Data: Computer bulletin board. Log on via modem through (703) 648-7799, or call (703) 648-7943 for technical assistance.

CD-ROM: A disc containing chapters of the Minerals Yearbook (1993-95), the Mineral Commodity Summaries (1995-97), a statistical compendium (1970-90), and other publications is updated three times a year and sold by the Superintendent of Documents, Government Printing Office (address above).

World Wide Web: http://minerals.er.usgs.gov/minerals/

\section{SUBSCRIPTION TO THE CATALOG "NEW PUBLICATIONS OF THE U.S. GEOLOGICAL SURVEY"}

Those wishing to be placed on a free subscription list for the catalog "New Publications of the U.S. Geological Survey" should write to the U.S. Geological Survey, 903 National Center, Reston, VA 20192. 


\section{The Sedimentary Carbonate-Hosted Giant Bayan Obo REE-Fe-Nb Ore Deposit of Inner Mongolia, China: A Cornerstone Example for Giant Polymetallic Ore Deposits of Hydrothermal Origin}

By E.C.T. Chao, J.M. Back, J.A. Minkin, M. Tatsumoto, Wang Junwen, J.E. Conrad, and E.H. McKee,

U.S. Geological Survey, U.S.A., Hou Zonglin and Meng Qingrun,

Tianjin Geological Research Academy, Ministry of Metallurgical Industry, China, and Huang Shengguang,

Baotou Steel and Rare Earth Corporation, Inner Mongolia, China

U.S. GEOLOGICAL SURVEY BULLETIN 2143

The work in this report was made possible by the U.S./People's Republic of China Earth Sciences Protocol between the Academy of Geological Sciences of the Ministry of Geology and Mineral Resources of China and the U.S. Geological Survey, Department of the Interior of the United States of America

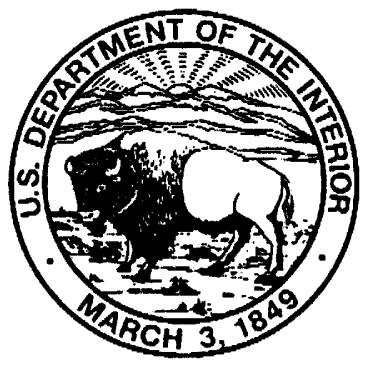

UNITED STATES GOVERNMENT PRINTING OFFICE, WASHINGTON : 1997 


\title{
U.S. DEPARTMENT OF THE INTERIOR BRUCE BABBITT, Secretary
}

\author{
U.S. GEOLOGICAL SURVEY \\ GORDON P. EATON, Director
}

For sale by U.S. Geological Survey, Information Services

Box 25286, Federal Center, Denver, CO 80225

Any use of trade, product, or firm names in this publication is for descriptive purposes only and does not imply endorsement by the U.S. Government.

Published in the Eastern Region, Reston, Va. Manuscript approved for publication June 28, 1995.

\section{Library of Congress Cataloging in Publication Data}

The sedimentary carbonate-hosted giant Bayan Obo REE-Fe-Nb ore deposit of Inner Mongolia, China : a cornerstone example for giant polymetallic ore deposits of hydrothermal origin / by E.C.T. Chao... [et al.].

p. cm.-(U.S. Geological Survey bulletin ; 2143)

Includes bibliographical references.

Supt. of Docs. no.: I 19.3:2143

1. Hydrothermal deposits-China-Inner Mongolia. 2. Earths, Rare-China-Inner

Mongolia. 3. Iron ores-China-Inner Mongolia. 4. Niobium ores-China-Inner

Mongolia. 5. Geology-China-Inner Mongolia. 6. Geology, Stratigraphic-

Proterozoic. I. Chao, E.C.T. II. Series. III. Series: U.S. Geological Survey bulletin ;

2143.

QE75.B9 no. 2143

[QE390.5]

$557.3 \mathrm{~s}-\mathrm{dc} 20$

[553.4'94'095177]

95-24696

CIP 


\section{CONTENTS}

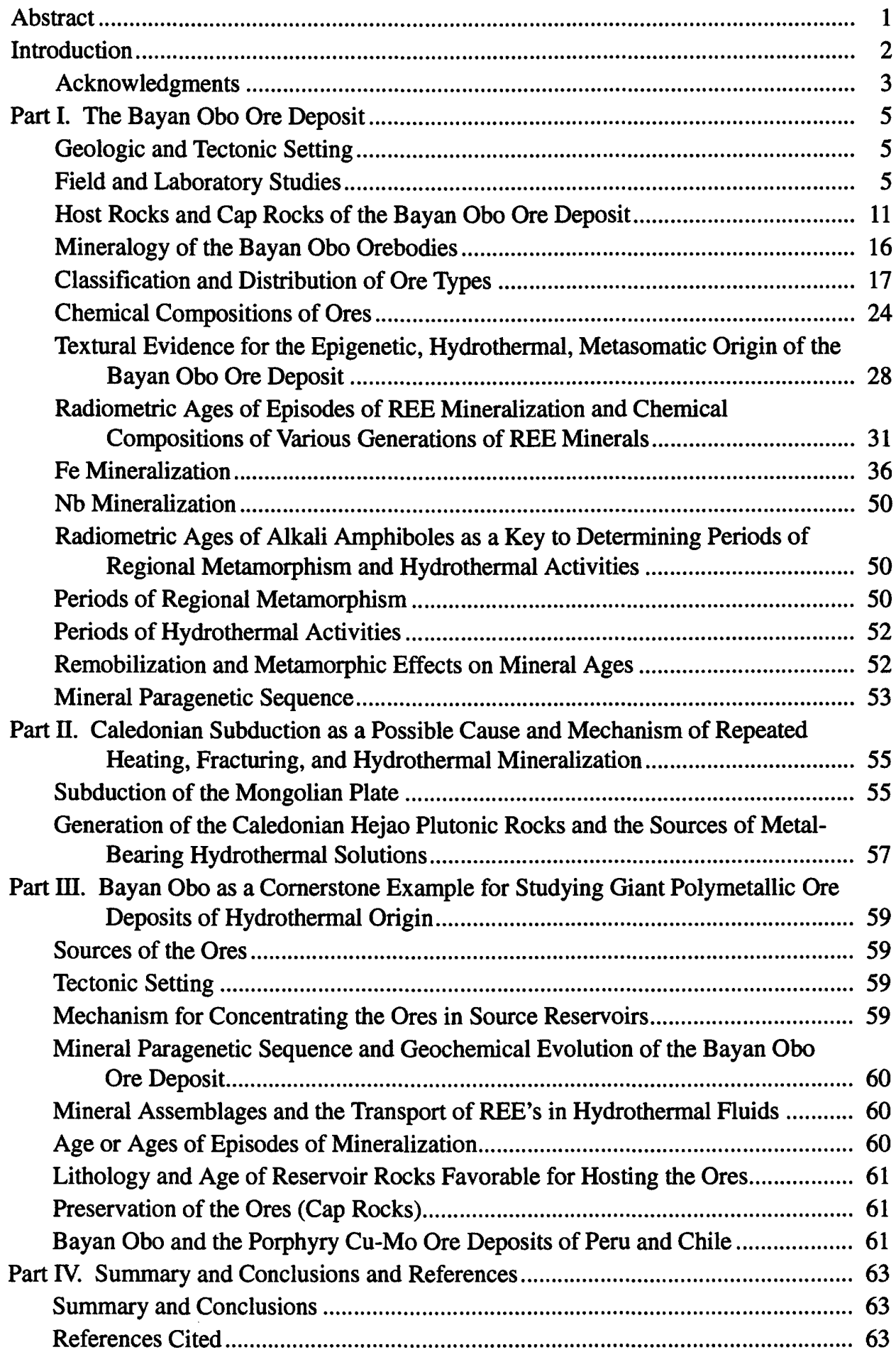




\section{FIGURES}

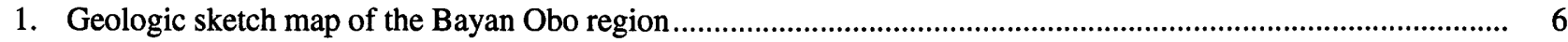

2. Generalized geologic map of the Bayan Obo study area ........................................................................ 7

3. Diagrams showing the deposit relation of the Chartai and Bayan Obo Groups as cover beds deposited on the continental slope of the North China Platform or craton

4. Paleotectonic map of northern China in the Caledonian period, showing locations of the Caledonian subduction, the Hercynian subduction, and the Caledonian Hejao anorogenic granites.

5. Map showing localities of samples taken in and near the Main and East Orebodies of Bayan Obo ...................... 10

6,7. Photomicrographs of-

6. A fine-grained dolostone marble (sample 7B34), showing banding parallel to bedding and lenses of scattered detrital quartz grains.

7. A coarse-grained dolostone marble (sample 7B34-16) containing rounded grains of detrital apatite and showing triple-junction grain boundary texture

8. Geologic sketch map of the Main and the East Orebodies of Bayan Obo

9-14. Photographs of-

9. Hand specimen (sample 7B30-1) of typical microfolded banded ore consisting of irregular to lenticular layers of monazite, granular hematite, and fluorite

10. Large block (sample 8B13) of banded ore consisting of layers of aegirine augite and magnetite.................. 21

11. Block (sample 9B3i) showing both fluorite and aegirine augite as major gangue minerals ........................... 22

12. Block (sample 9B13) of banded ore consisting of granular apatite, granular hematite, and monazite........... 22

13. Outcrop on bench $1582 \mathrm{~m}$ of the East Orebody, showing bodies of massive magnetite and hematite ores ... 23

14. Block of $\mathrm{H} 8$ dolostone marble partly replaced by disseminated magnetite

15-17. Photomicrographs of doubly polished thin sections of -

15. The host dolostone marble (sample 7B36-'90) showing granulation texture and interstitial replacement of granulated grains of dolomite by very fine grained monazite

16. Banded fluorite dolostone marble (sample 7B30-2) showing fluorite replacement of dolomite at triplejunction grain boundary

17. Marble (sample $796-48,449$ ) showing relict dolomite grains surrounded by fine granular aegirine augite that partially replaced dolomite

(1)

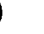


31, 32. Diagrams showing radiometric ages of minerals in-

31. Sample 796-48,277

32. Sample 8B7

33. Summary diagram of $\mathrm{K}$ - $\mathrm{Ar}$ and ${ }^{40} \mathrm{Ar}{ }^{39} \mathrm{Ar}$ minimum mineral ages of alkali amphiboles of both metasomatic and metamorphic origin from samples of the Bayan Obo REE-Fe-Nb ore deposit, Inner Mongolia, China

34. Schematic diagram showing five stages of north to south subduction of the Siberian oceanic plate under the northern margin of the North China craton

35. Diagram showing the ${ }^{39} \mathrm{Ar}$ release pattern of incremental heating of hornblende from a quartz monzonite rock, sample 8B53-1, collected near Hejao, showing a plateau ${ }^{40} \mathrm{Ar}{ }^{\beta 9} \mathrm{Ar}$ Caledonian age of $455.0 \pm 3.4 \mathrm{Ma} \ldots . .$.

\section{TABLES}

1. Principal minerals of the Bayan Obo ore deposit.

2-5. Chemical composition of samples from Bayan Obo:

2. Ferroan dolomite in $\mathrm{H} 8$ dolostone marble ....

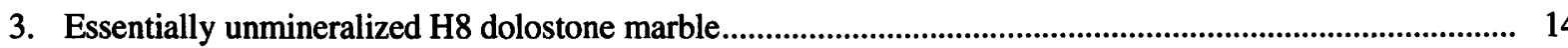

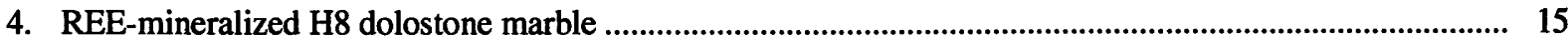

5. Huanghoite, apatite, and aegirine augite ............................................................................................... 17

6-12. Partial chemical composition of ores from Bayan Obo:

6. Disseminated monazite ore in dolostone marble and monazite-hematite-apatite banded ores...................... 25

7. Selected monazite( \pm bastnaesite)-fluorite (low-Fe, high REE) banded ores ................................................. 25

8. Bastnaesite-apatite-aegirine augite-fluorite \pm martite banded ores with apatite \pm barite..................................... 26

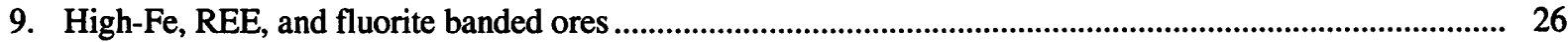

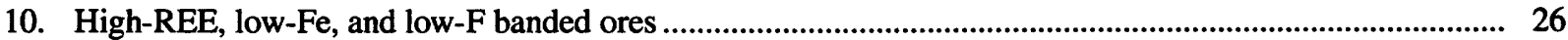

11. Marble-hosted alkali amphibole-magnetite banded ores .......................................................................... 27

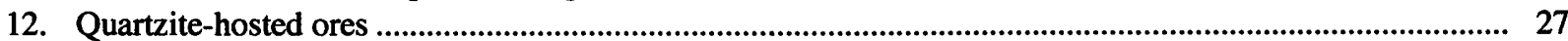

13. Generalized mineral paragenetic sequence of Bayan Obo....................................................................... 29

14. Partial chemical composition and internal isochron mineral ages of monazites and bastnaesites of Bayan Obo

15. Chemical composition and minimum mineral ages of various generations of selected alkali amphiboles of Bayan Obo

\section{CONVERSION FACTORS}

\begin{tabular}{rll}
\hline Multiply & By & To obtain \\
\hline micrometer $(\mu \mathrm{m})$ & 0.000039 & inch \\
centimeter $(\mathrm{cm})$ & 0.3937 & inch \\
kilometer $(\mathrm{km})$ & 0.6214 & mile \\
metric ton & 1.102 & ton \\
degree Celsius $\left({ }^{\circ} \mathrm{C}\right)$ & 1.8 and add 32 & degree Fahrenheit \\
\hline
\end{tabular}




\section{ABBREVIATIONS, ACRONYMS, AND SYMBOLS}

\section{TIME}

$\mathrm{Ma}$

$\mathrm{Ga}$

m.y.

wt. percent

$\%$

ppm

$\mathrm{ppb}$

HREE

LREE

REE

$\mathrm{Re}_{2} \mathrm{O}_{3}$

EPMA

ICP-AES

ICP-MS

INAA

ISE

SEM-EDX

SXRF

WDXRF

DPTS

MDL

USGS mega-annum, $10^{6}$ years ago

giga-annum, $10^{9}$ years ago

million $\left(10^{6}\right)$ years

\section{CONCENTRATION}

weight percent

per mil, parts per thousand $\left(10^{3}\right)$

parts per million $\left(10^{6}\right)$

parts per billion $\left(10^{9}\right)$

\section{RARE EARTH ELEMENTS AND OXIDES}

heavy rare earth element

light rare earth element

rare earth element

rare earth oxides

\section{ANALYTICAL METHODS}

electron microprobe analysis

inductively coupled plasma-atomic emission spectrometry

inductively coupled plasma-mass spectrometry

instrumental neutron activation analysis

ion-selective electrode

scanning electron microscopy with energy-dispersive $\mathrm{X}$-ray analysis

synchrotron X-ray fluorescence analysis

wavelength-dispersive $\mathrm{X}$-ray fluorescence spectrometry

\section{MISCELLANEOUS}

doubly polished thin section

minimum detection level

U.S. Geological Survey 


\title{
The Sedimentary Carbonate-Hosted Giant Bayan Obo REE-Fe-Nb Ore Deposit of Inner Mongolia, China: A Cornerstone Example for Giant Polymetallic Ore Deposits of Hydrothermal Origin
}

\author{
By E.C.T. Chao, J.M. Back, J.A. Minkin, M. Tatsumoto, \\ Wang Junwen, J.E. Conrad, and E.H. McKee, \\ U.S. Geological Survey, U.S.A., \\ Hou Zonglin and Meng Qingrun, \\ Tianjin Geological Research Academy, Ministry of Metallurgical Industry, China, \\ and Huang Shengguang, \\ Baotou Steel and Rare Earth Corporation, Inner Mongolia, China
}

\begin{abstract}
Detailed, integrative field and laboratory studies of the textures, structures, chemical characteristics, and isotopically determined ages and signatures of mineralization of the Bayan Obo deposit provided evidence for the origin and characteristics favorable for its formation and parameters necessary for defining giant polymetallic deposits of hydrothermal origin. Bayan Obo is an epigenetic, metasomatic, hydrothermal rare earth element (REE)-Fe- $\mathrm{Nb}$ ore deposit that is hosted in the metasedimentary $\mathrm{H} 8$ dolostone marble of the Middle Proterozoic Bayan Obo Group. The metasedimentary sequence was deposited on the northern continental slope of the North China craton. The mine area is about 100 $\mathrm{km}$ south of the suture marking Caledonian subduction of the Mongolian oceanic plate from the north beneath the North China craton.

The mineralogy of the deposit is very complex, consisting of more than 120 different minerals, some of which are epigenetic minerals introduced by hydrothermal solutions, and some of which are primary and secondary metamorphic minerals. The major REE minerals are monazite and bastnaesite, whereas magnetite and hematite are the dominant Fe-ore minerals, and columbite is the most abundant $\mathrm{Nb}$ mineral. Dolomite, alkali amphibole, fluorite, barite, aegirine augite, apatite, phlogopite, albite, and microcline are the most widespread gangue minerals.

Three general types of ores occur at Bayan Obo: disseminated, banded, and massive ores. Broad zoning of these ore types occurs in the Main and East Orebodies. Disseminated ores are in the outermost zone, banded ores are in the intermediate zone, and massive ores are in the cores of the orebodies. On the basis of field relations, host rocks, tex-
\end{abstract}

tures, structures, and mineral assemblages, many varieties of these three types of ores have been recognized and mapped.

Isotopic dating of monazite, bastnaesite, aeschynite, and metamorphic and metasomatic alkali amphiboles associated with the deposit provides constraints on the ages of mineralization and the history of the deposit. Textural relations, differences in chemical composition, and ${ }^{232} \mathrm{Th} /{ }^{208} \mathrm{~Pb}$ internal isochron ages of monazite and bastnaesite samples indicate that many episodes of REE mineralization occurred at Bayan Obo, ranging from about $555 \mathrm{Ma}$ to about $398 \mathrm{Ma}$. Initial ${ }^{208} \mathrm{~Pb} /{ }^{204} \mathrm{~Pb}$ ratios suggest different sources of REE's for different generations of REE minerals. Relative ages of $\mathrm{Fe}$ mineralization were deduced from textural relationships of Fe minerals with other, dated mineral phases in the deposit. Most Nb mineralization was in the area of the West Orebodies and resulted in disseminated ore. Aeschynite, an early stage of $\mathrm{Nb}$ mineralization $(438.2 \pm 25.1 \mathrm{Ma})$, occurs with huanghoite and alkali amphiboles in veins.

The ${ }^{40} \mathrm{Ar} /{ }^{39} \mathrm{Ar}$ ages of amphiboles, as well as petrographic textures, were used to distinguish three periods of regional metamorphism in the Bayan Obo mine area: (1) Late Proterozoic, about 890 Ma, which recrystallized H8 carbonate to marble and crystallized lineated alkali amphiboles along foliation planes in the marble; (2) Caledonian, about 425-395 Ma, which resulted in metamorphic and metasomatic-metamorphic alkali amphiboles; and (3) Hercynian, about $300 \mathrm{Ma}$, based on biotite ${ }^{40} \mathrm{Ar} /{ }^{39} \mathrm{Ar}$ analyses from biotite schist and folded banded ores. The ${ }^{40} \mathrm{Ar} /{ }^{39} \mathrm{Ar}$ ages of metasomatic alkali amphiboles also place time constraints on the hydrothermal history of the ore deposit. Metasomatic amphiboles represent periods of intense hydrothermal activity, which began as early as $1.26 \mathrm{Ga}$; that 
date is based on the age of amphibole from a vein that crosscuts the $\mathrm{H} 6$ quartzite that underlies the $\mathrm{H} 8$ dolostone marble. Although much of the metasomatic amphibole formed during periods that overlapped the peak period of REE mineralization of banded ores, REE and alkali amphibole phases generally occur in different mineral assemblages or are of very different ages in the same assemblage and, therefore, may have been derived from unrelated fluids. The ages of amphiboles in veins that crosscut banded ores indicate that the last stage of banded ores had formed by about $396 \mathrm{Ma}$.

Two intense periods of subduction of the Mongolian oceanic plate beneath the North China craton during the Paleozoic era, and an intervening period of extension, may account for the repeated heating, fracturing (extensional tectonics), hydrothermal mineralization, and regional metamorphism (compressional tectonics) at Bayan Obo. Caledonian Hejao granitic plutonic rocks intruded the Bayan Obo Group along a major fault zone and were subsequently intruded by Hercynian granitic rocks about $50 \mathrm{~km}$ south of the mine area. Although the Hejao granitic rocks are low in REE's and therefore probably have a different crustal source than the REE-mineralizing hydrothermal solutions that formed the REE's deposit, both probably resulted from Caledonian subduction.

On the basis of this study, we have selected eight parameters necessary to evaluate and understand the conditions needed for the formation of giant polymetallic deposits of hydrothermal origin, regardless of the type of ore deposit: (1) sources of the ores, (2) tectonic setting, (3) mechanism for concentrating and transporting the ore-bearing fluids, (4) mineral paragenetic sequence and geochemical evolution of the ore deposit, (5) mineral assemblages and transport of ore by hydrothermal fluids, (6) age or ages of episodes of mineralization, (7) lithology of reservoir rocks favorable for hosting ores, and (8) preservation of ores. Although of different ore type than Bayan Obo, the Andean giant and super giant porphyry Cu-Mo ore deposits that occur from Peru to Chile can be compared with Bayan Obo in order to study the importance of tectonic setting and duration of mineralization on the formation of giant deposits. Both Bayan Obo and the Andean porphyry Cu-Mo deposits are related to subduction of oceanic plates, and both were formed over long periods of time. In Bayan Obo, REE mineralization occurred over a period of more than 150 million years (555 Ma to $398 \mathrm{Ma}$ ). Mineralization of many different porphyry $\mathrm{Cu}-\mathrm{Mo}$ ore deposits occurred over a period of about 95 million years (100 to $5 \mathrm{Ma}$ ) (Clark, 1993), and Clark (1993) summarized the migration of porphyry $\mathrm{Cu}$ mineralization in the Andes from north to south over a period of 50 million years.

\section{INTRODUCTION}

Bayan Obo is a giant polymetallic rare earth element (REE)-Fe-Nb ore deposit of hydrothermal origin in Inner Mongolia, China. Earlier studies were reviewed by Chao and others (1990, 1992, 1993). Detailed corroborative field and laboratory studies of textural and structural relations, chemical compositions of various generations of gangue and ore minerals, and isotopic and radiometric data on gangue and ore minerals were obtained during our research in order to describe and interpret the characteristics and origin of this deposit. On the basis of the results of this study, we consider Bayan Obo a cornerstone example for giant polymetallic deposits of hydrothermal origin. In spite of the unique polymetallic ore types, very complex mineralogy, and history of regional metamorphism and mineralization, Bayan Obo can be compared with other, different giant polymetallic deposits of hydrothermal origin.

The Bayan Obo deposit was first discovered as an Fe deposit in 1927, and later was recognized as a polymetallic deposit of Fe, REE's, and $\mathrm{Nb}$. The estimated total reserve of $\mathrm{Fe}$ (average grade $\mathrm{Fe}=35$ weight (wt.) percent) for the Bayan Obo deposit is at least 1,500 million metric tons (Drew and others, 1990). On the basis of reported estimates of a total reserve of 48 million metric tons (average grade 6 wt. percent $\mathrm{RE}_{2} \mathrm{O}_{3}$, Drew and others, 1990) to as much as 100 million metric tons of $\mathrm{RE}_{2} \mathrm{O}_{3}$ of unspecified average grade (unofficial estimate from Chinese colleagues, oral commun., 1987), Bayan Obo is the world's largest known REE ore deposit. Recently, on the basis of drilling data, the Bayan Obo ore deposit was also acknowledged as the largest $\mathrm{Nb}$ deposit in China. Although the size has not been disclosed in the Chinese literature, Drew and others (1990) estimated the total reserve of $\mathrm{Nb}$ from Bayan Obo as 1 million metric tons of average grade of $0.13 \mathrm{wt}$. percent $\mathrm{Nb}$.

In this paper, part I describes the overall characteristics of the Bayan Obo ore deposit on the basis of updated field and laboratory findings, and data from previous work by other investigators that are pertinent to this study. Part II presents data available on the Caledonian subduction of the oceanic plate from the north under the North China craton. This continued subduction may have provided a mechanism of repeated activation of heating and fracturing of the lower crust, a mechanism that possibly produced the Caledonian plutonic rocks of Hejao, $50 \mathrm{~km}$ south of the mine region, and may have also generated acid hydrothermal solutions that scavenged and concentrated the sources of ore for the Bayan Obo deposit. Part III examines Bayan Obo as a cornerstone example of giant ore deposits of hydrothermal origin, with respect to eight parameters of importance in the 
formation of these deposits. Part IV presents a summary and conclusions and references.

\section{Acknowledgments}

This joint research was made possible under the U.S./ People's Republic of China Earth Sciences Protocol between the Academy of Geological Sciences of the Ministry of Geology and Mineral Resources of China and the U.S. Geological Survey (USGS), Department of the Interior of the United States of America. Geologists of the Tianjin Geological Research Academy, Ministry of Metallurgical Industry, played a major role as joint research participants.

We thank chief engineer Professor Yao Peihui and Ms. Hu Pinmei of the Geological Bureau of the Ministry of Metallurgical Industry for support of this joint research and for providing the necessary clearance for us to conduct field research and collect samples in the Bayan Obo mine region.
We are grateful to Zhang Guozhong, general manager of the Baotou Steel and Rare Earth Corporation, and Jiang Guojen, director of the Bayan Obo mine, for their assistance in providing access to and use of the facilities at the mine. We thank mine geologist Wu Janjiang for guidance to critical outcrops both inside and outside of the Main and East Orebodies. We also thank Professor Ren Yingchen and other members of the Tianjin Geological Research Academy for providing additional Bayan Obo samples from their collections for this joint research.

We thank the following USGS colleagues for their managerial support: Tom Ovenshine, Glen Alcott, John DeYoung, Jr., Bruce Lipin, and Klaus Schulz. We thank our colleagues J.E. Taggart, A. Bartel, D. Siems, P.H. Briggs, and James Crock for their contributions to the analyses of unmineralized and weakly mineralized marble samples and partial chemical analyses of ores. We also thank our colleagues George Ericksen and Bruce Doe for their technical reviews of this manuscript. 



\section{PART I. THE BAYAN OBO ORE DEPOSIT}

\section{GEOLOGIC AND TECTONIC SETTING}

Bayan Obo is a stratabound ore deposit hosted by Proterozoic marble of the Bayan Obo Group. The regional distributions of the Proterozoic Bayan Obo Group, the Archean metamorphic rocks of the Wutai Group, which unconformably underlies the Bayan Obo Group, and granitic rocks of Archean, Caledonian (early to late Paleozoic), and Hercynian (Permian) ages in the region are shown in figure 1. Alkaline plutonic or volcanic rocks have not been reported in this region and evidently are not present. The Bayan Obo mine area (fig. 2) is separated from the area to the north by a major fault zone, the Kuanggou fault. The differences of lithology and degree of metamorphism and mineralization on either side of the fault indicate that the age of the Kuanggou fault is probably post-late Caledonian (younger than $400 \mathrm{Ma}$; Chao and others, 1992). The geology of the region north of the Kuanggou fault, which is broken by many extensional and thrust faults, is distinctly different from that of the mine area, and the stratigraphic sequence there has been designated as an undifferentiated unit of Proterozoic to Paleozoic sedimentary rocks.

According to Bai and Yuan (1985), Li Yuying subdivided the Bayan Obo Group into nine lithologic units; a detailed stratigraphic section measured in the vicinity of the mine by Meng (1982) also distinguished nine lithologic units. This section was subsequently described in greater detail by Chao and others (1992). The lower part of the group (Hu, fig. 2) consists of arkosic quartzite (H1), fine- to medium-grained quartzite (H2), dark carbonaceous slate (H3), arkosic quartzite and slate (H4), slate with intercalated silty sandstone and quartzite (H5), a ridge-forming quartzite (H6), and transitional beds of dolostone marble, arkosic sandstone, and calcareous slate (H7). Overlying this lower sequence is the dominant ore-bearing unit, $\mathrm{H} 8$, which ranges from 240 to $540 \mathrm{~m}$ in thickness, the thickest part being near the Main and the East Orebodies. The H8 unit consists of dolostone marble and subordinate limestone marble, intercalated with quartzite in the upper and lower parts. Small amounts of porphyroblastic albite biotite schist and biotite-rich minette occur as lenses within this unit. The uppermost lithologic unit, H9, 340-350 m thick, consists of a sequence of interbedded gray to black shale, slate, and biotite schist that conformably overlies the $\mathrm{H} 8$ unit.

A small swarm of 11 calcitic carbonatite dikes, mostly 1-2 $\mathrm{m}$ wide and up to $150 \mathrm{~m}$ long, cut across an anticlinal structure in the Archean Wutai granitic gneisses and mig- matites, approximately $1.5 \mathrm{~km}$ northeast of the mine area. The largest of these dikes was studied in detail by Le Bas and others (1992). Another meter-wide, dolomitic carbonate dike that cuts $\mathrm{H} 1$ or $\mathrm{H} 4$ arkosic quartzite northeast of the mine was recently discovered. The alkali amphibole in the fenitized contact zone of this carbonatite gave an ${ }^{40} \mathrm{Ar} /{ }^{39} \mathrm{Ar}$ plateau age of $1.28 \mathrm{Ga}$ (Ren Yingchen, oral commun., 1993).

South of the Kuanggou fault zone, the Bayan Obo Group crops out in a broad syncline in which the $\mathrm{H} 8$ and $\mathrm{H} 9$ units form the central part. The north limb of the syncline dips generally $50^{\circ}-70^{\circ} \mathrm{S}$. The south limb is steeper, generally dipping $70^{\circ}-80^{\circ} \mathrm{N}$., but locally it is vertical or is slightly overturned (Meng, 1982). This syncline has many small chevron folds, meter-wide shear zones, and thrust faults, all trending east-west. Many of the more strongly mineralized zones in the orebodies follow the east-trending shear zones.

On the basis of sequential stratigraphic analysis, Qiao and others (1991) correlated the Bayan Obo Group with the Chartai Group and interpreted both groups as having been deposited on the North China Platform or craton (fig. 3). The Chartai Group was deposited on the continental shelf, whereas the Bayan Obo Group was deposited on the continental slope of the craton. The Bayan Obo mine area is about $100 \mathrm{~km}$ south of the suture marking Caledonian subduction (fig. 4; Wang, 1985) that took place at the northern edge of the North China Platform or craton. A small granitic intrusion of Caledonian age occurs in the Hejao area, south of Bayan Obo (fig. 1). No direct evidence of rifting involving the Bayan Obo Group in the mine region was observed, although rifting was cited by Wang and others (1991) on the basis-of geophysical evidence and the reported occurrence of volcanic rocks in the Chartai and Bayan Obo Groups.

\section{FIELD AND LABORATORY STUDIES}

Field studies consisted of identifying and sampling the many rock and ore types in the Bayan Obo mine area and determining the geographical extent and relations of the ore types. About 830 samples, including samples from three drill cores, were collected in the summers of 1987, 1988, and 1990. Sampling localities in and near the Main and East Orebodies are shown in figure 5. Locations of other samples provided by colleagues of the Tianjin Geological Research Academy, which are not known, are not given in figure 5. 


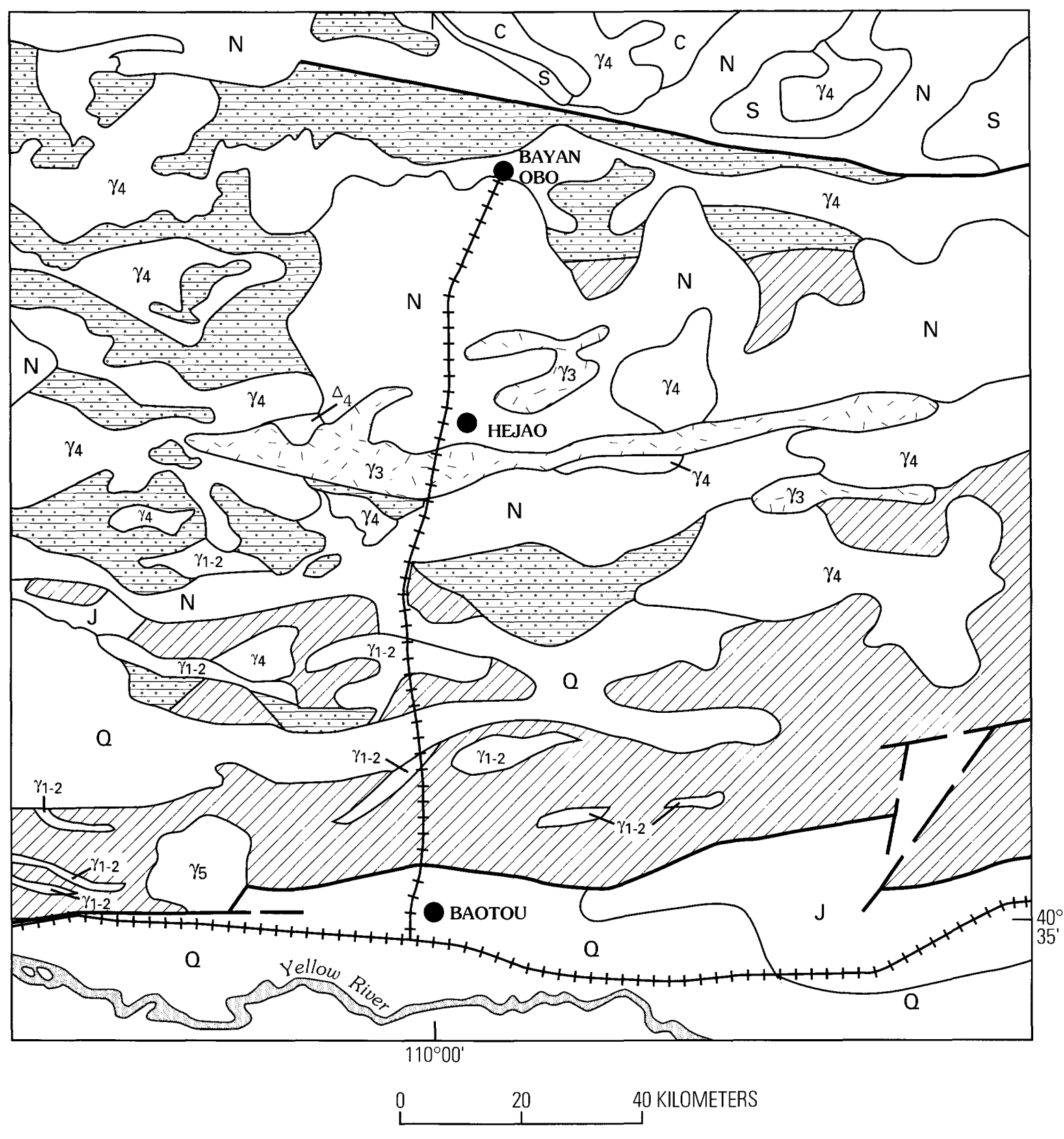

EXPLANATION

DEA wutai Group (Archean) $\because \because{ }^{\circ}$
Bayan Obo Group
(Middle Proterozoic)

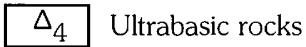

Fault-Dashed where inferred

$+1+$ Railroad
Q Quaternary sediments

SEDIMENTARY ROCKS

$\mathrm{N}$ Tertiary

$\mathrm{J}$ Jurassic

C Carboniferous

S Silurian

\section{GRANITIC ROCKS}

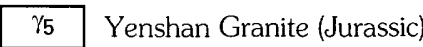

$\gamma_{4}$ Hercynian Granite

$\gamma_{3}$ Caledonian Granite

$\gamma_{1-2}$ Wutai Granite (Archean)

Figure 1. Geologic sketch map of the Bayan Obo region (modified from Institute of Geochemistry, 1988). 


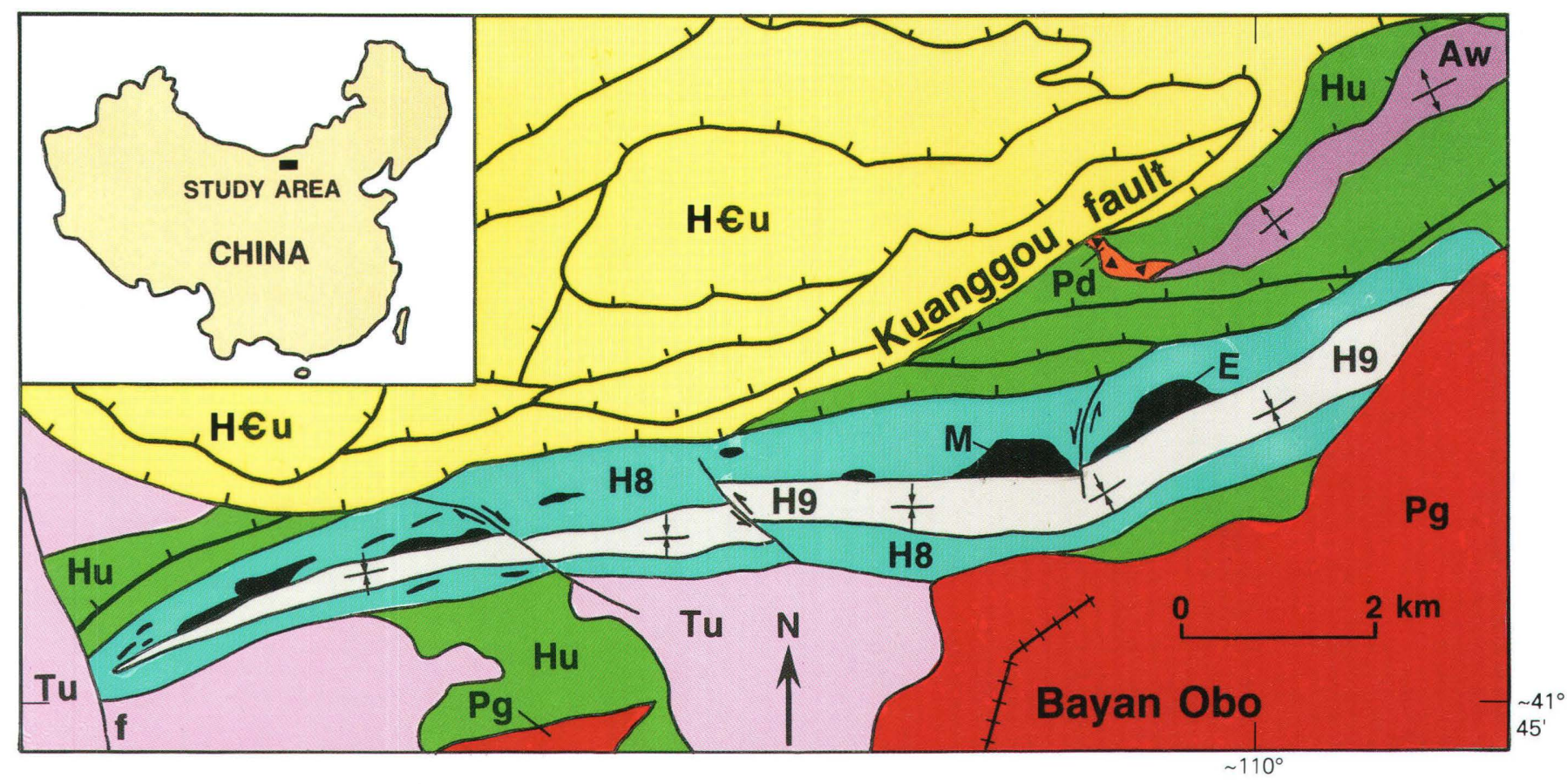

\section{EXPLANATION}

(The unit symbols for the Bayan Obo Group are used in accordance with standard Chinese geologic symbols

for Middle Proterozoic)

\section{Bayan Obo Group (Middle Proterozoic)}

Tu Sedimentary rocks, undivided (Tertiary)

$\checkmark \mathrm{P}^{4} \mathrm{~d}$ Diorite (Permian)

Pg Granite rocks (Permian)

HEu Sedimentary rocks, undivided
(Proterozoic and Cambrian)
H9 Shale, slate, and schist

H8 Dolostone and limestone marble

$\mathrm{Hu}$ Sedimentary rocks (H1-H7), undivided

Aw Wutai Group (Archean)—Gneisses

\section{SYMBOLS}

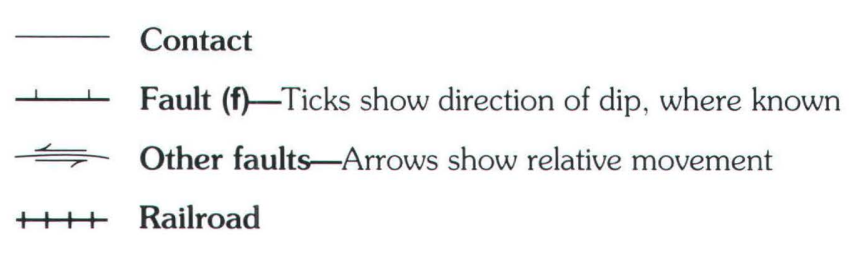

Figure 2. Generalized geologic map of the Bayan Obo study area (modified from Chao and others, 1992). 


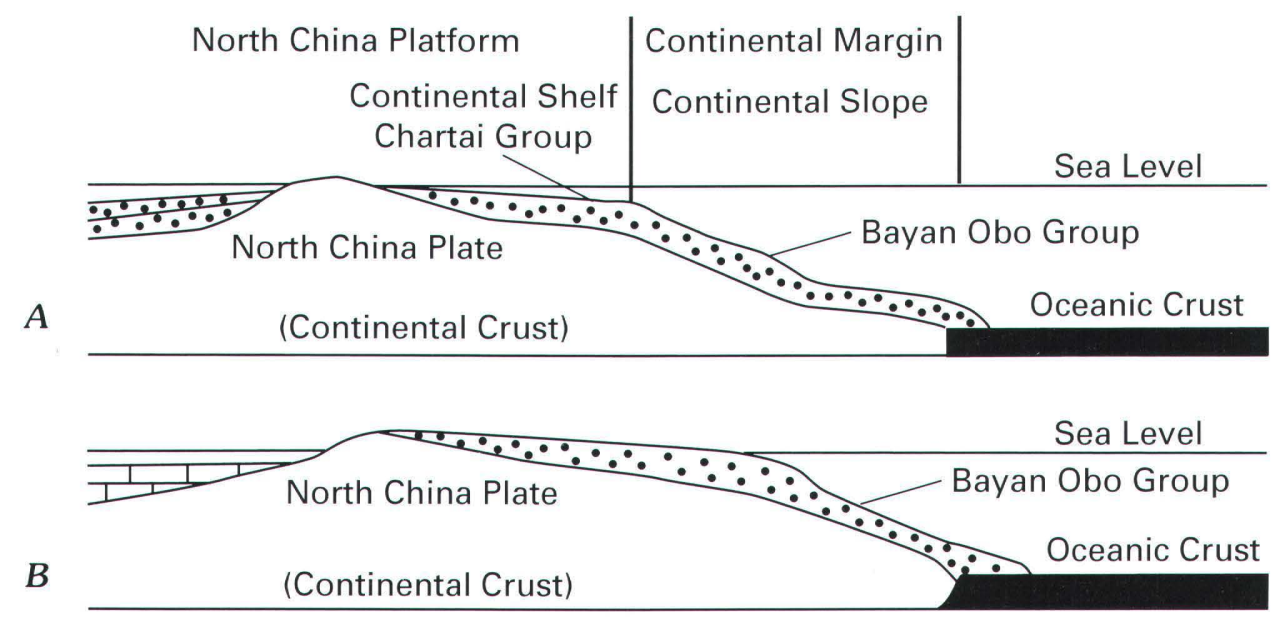

Figure 3. Deposit relation of the Chartai and Bayan Obo Groups as cover beds deposited on the continental slope of the North China Platform or craton (modified from Qiao and others, 1991). $A$, Advance of the sea at an earlier stage, when the Chartai Group was deposited. $B$, Retreat of the sea at a later stage, when the Bayan Obo Group was deposited.

Figure 4. Paleotectonic map of northern China in the Cale- $\rightarrow$ donian period (modified from Wang, 1985), showing locations of the Caledonian subduction, the Hercynian subduction, and the Caledonian Hejao anorogenic granites.
过渡型及大洋型地壳

TRANSITIONAL \& OCEANIC OF CRUST

SO 连续沉积, 边缘海、大陆斜坡、 海槽末分

SD continuous, marginal seas, conti-

nental slopes \& sea troughs

洋塞

oceanic crust

其它

OTHERS

$\mathrm{O}_{2}$ 粗碎粡沉积

$\mathrm{O}_{2}$ coarse clastic deposits

早中加里东期 $(€ 0)$ 变质带及混合

1 1 1 岩带

E. \& M. Caledonian $(€ 0)$ metamorphic \& migmatite zones

花岗岩类侵入, 左: 早加里东期

$+{ }^{+}+{ }^{+}+(>4.4$ 亿年 $)$, 右: 晚加里东期

( 4.4-3.9 亿年)

granitic intrusives, left: E. Caledonian (> 440 m. .. ), right: L. Caledonian (440-390 m.y.)

X 岛弧火山沉积组合, 左: $e 0$, 右: 0

$x \quad$ island arc volcano-sedimentary ass. left: $\in O$, right: $0 S$ 


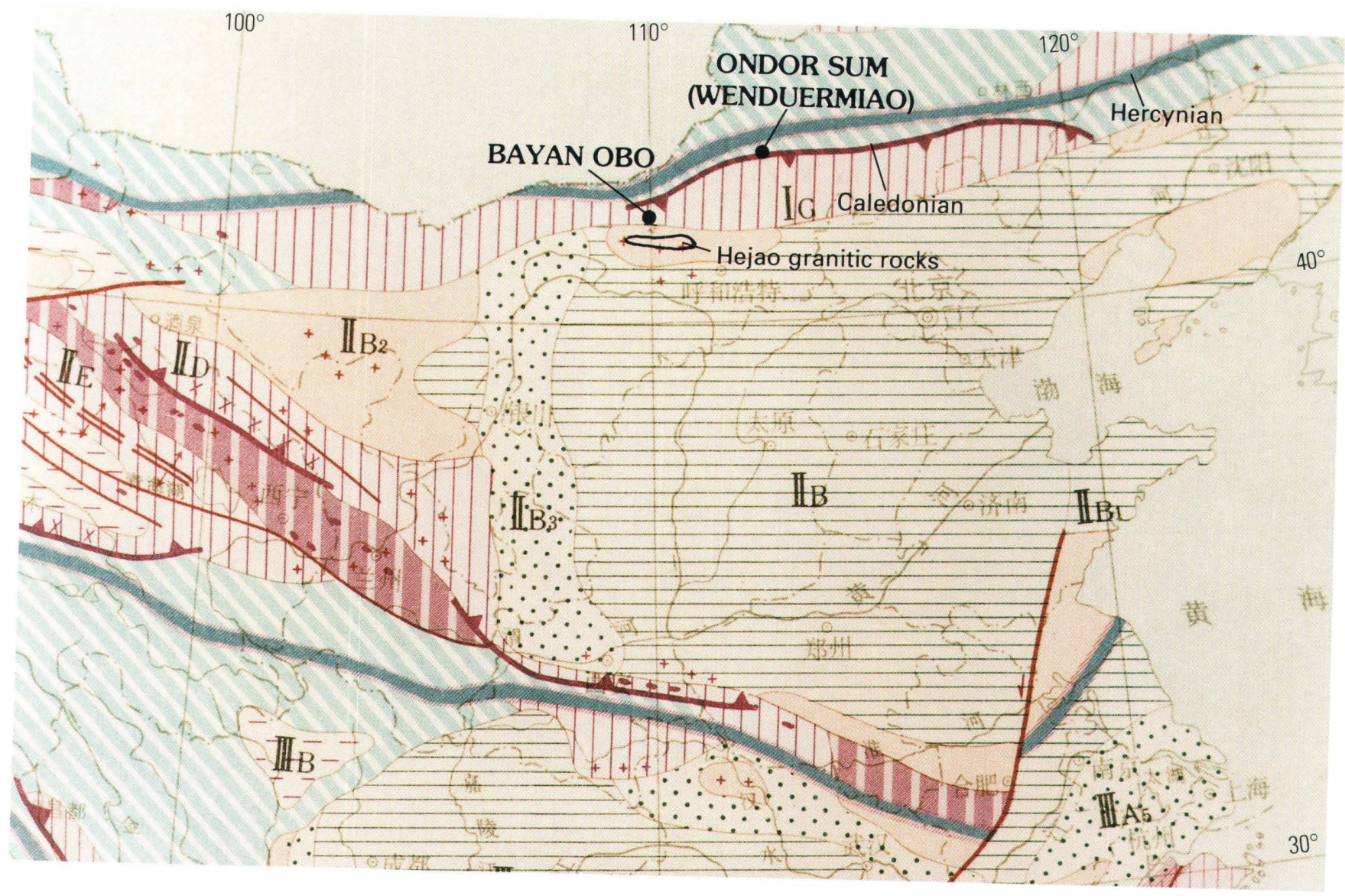

大陆型地壳CONTINENTAL TYPE OF CRUST

稳定区 Stable terrains

长期隆起, $€$ 后基本上升隆起

long term positive region, uplifted after $\epsilon$

陆表海碳酸盐细碎属沉积为主, 华北 $\mathrm{O}_{2}$ 后上

升, 扬子区 $S_{1}$ 后上升

epicontinental, carbonate to fine clastic mainly, $\mathrm{N}$.

China uplifted after $\mathrm{O}_{2}$, Yangtze region uplifted after $S$.

地台沉降带, 华北 $\mathrm{O}_{3}$ 后上升, 扬子区西部 $\mathrm{O}_{1}$

$\therefore \therefore$ 后上升, 扬子区东部 $\mathrm{S}_{1}$ 后上升

$\therefore$ intraplatform subsiding zone, N. China uplifted after $\mathrm{O}_{3}$, Yangtze region western part uplifted after $O_{i}$, eastern part uplifted after $s_{1}$

- - - 稳定地块末分

____ stable massifs undifferentiated
活动区 Mobile terrains

$\mathrm{P}_{3}$ 末隆起或早加里东 (兴凯期) 袺带

uplifted end of $\mathrm{P}_{3}$ or E. Caledonian (Xingkaian) fold zone

中加里东袹带, 边缘海非补偿沉积为主

$M$. Caledonian fold zone, marginal seas mainiy uncompensated

中加里东褔带, 边缘海、海槽补偿充填为主 M. Caledonian fold zone, marginal sea \& troughs mainly compensated

晚加里东褶带, 残存海槽、S后充填上升

L. Caledonian fold zone, residual sea trough, filled \& uplifted after $S$

Figure 4. Continued. 


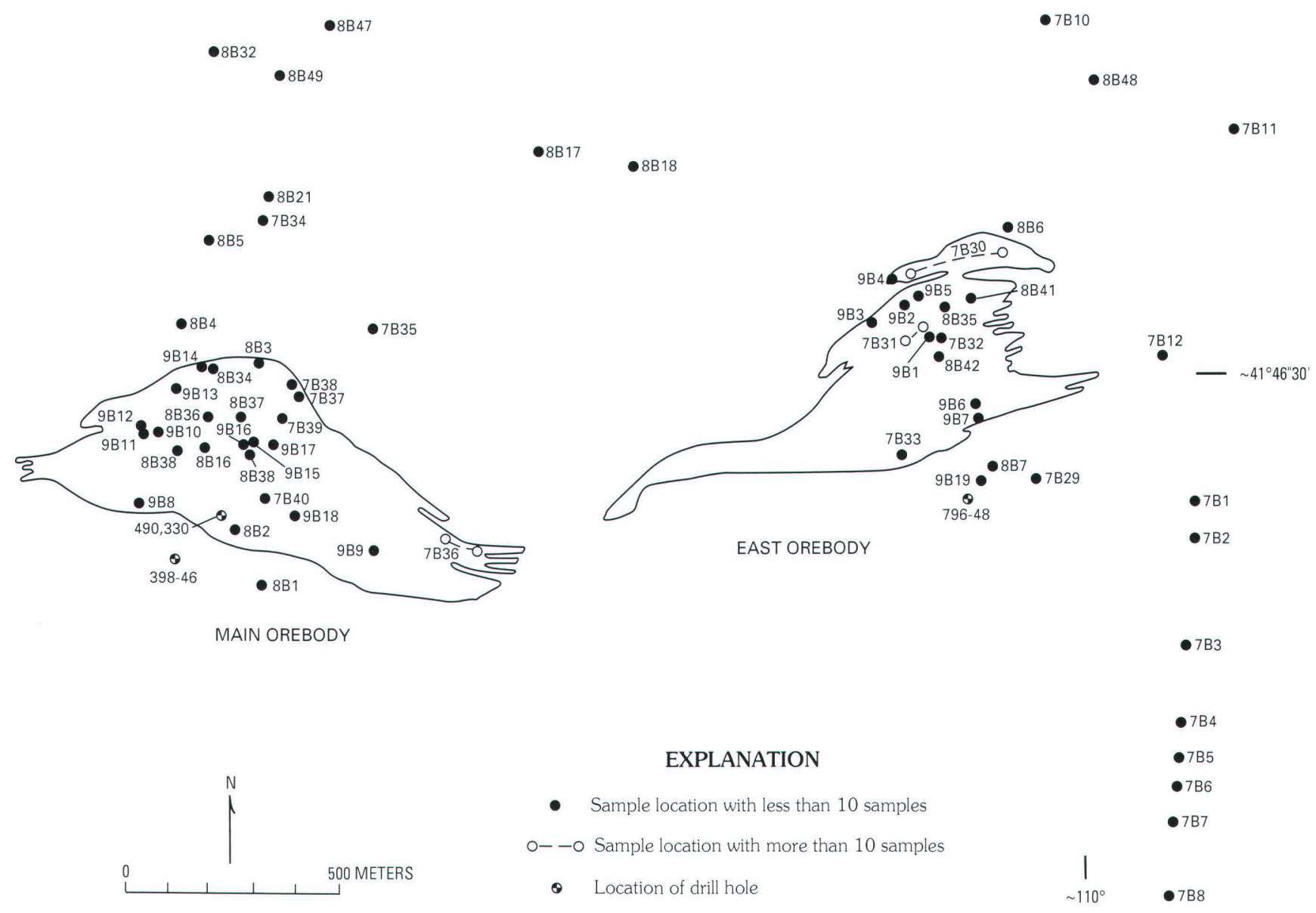

Figure 5. Localities of samples taken in and near the Main and East Orebodies of Bayan Obo.

A few samples from the West Orebodies (16 small orebodies in an area extending about $8 \mathrm{~km}$ west of the Main Orebody) are also not shown in figure 5. In the summers of 1988 and 1990, the preliminary mineral paragenetic sequences established petrographically from doubly polished thin sections (DPTS's) were checked in the field to confirm consistencies with field relations. Samples collected in 1987, 1988, and 1990 are numbered with a prefix 7B, 8B, and 9B, respectively, followed by the sample location number. For example, samples from 7B30 were collected in 1987 at sample location number 30. Samples 7B30-1, 7B30-20, and 7B30-30 are three separate samples from sample location 7B30. Except for drill cores, samples without a prefix $7 \mathrm{~B}, 8 \mathrm{~B}$, or $9 \mathrm{~B}$ were provided by colleagues from Tianjin.

In this paper, we use the following grain-size designations: coarse, $>500 \mu \mathrm{m}$; medium, $250-500 \mu \mathrm{m}$; fine, 125 $250 \mu \mathrm{m}$; very fine, $62-125 \mu \mathrm{m}$; and extremely fine, $<62 \mu \mathrm{m}$. Because of the extremely fine grain size of most of the ore and gangue minerals in the Bayan Obo area, interference microscopy was used for identification of the minerals in DPTS's (Chao and Xie, 1990). Routine identification of very and extremely fine grained minerals was accomplished by preliminary optical microscopy and verified by scanning electron microscopy with energy-dispersive $\mathrm{X}$-ray analysis (SEM-EDX). The optical and SEM-EDX studies were iterative because SEM-EDX usually examined smaller areas than optical microscopy. X-ray diffraction techniques were rarely used because of the difficulty of obtaining pure mineral concentrates from the extremely fine grained ores. Both optical microscopy and SEM were used for textural analysis of mineral replacement relations.

Most mineral compositions were obtained by electron microprobe analysis (EPMA), using carefully selected and calibrated standards. Other techniques were also used to determine compositions of individual minerals. For example, monazites and bastnaesites were analyzed by isotope dilution techniques (Wang and others, 1994), by instrumental neutron activation analysis (INAA), and by synchrotron $\mathrm{X}$-ray fluorescence analysis (SXRF) in a few cases (Chen 
Table 1. Principal minerals of the Bayan Obo ore deposit.

[REE's, rare earth elements]

\begin{tabular}{|c|c|}
\hline Mineral category & Principal minerals \\
\hline Host rock minerals & $\begin{array}{l}\text { ferroan dolomite } \\
\text { Sr- and Mn-calcite } \\
\text { quartz } \\
\text { illite } \\
\text { biotite } \\
\text { apatite } \\
\text { albite }\end{array}$ \\
\hline REE ore minerals & $\begin{array}{l}\text { monazite, }(\mathrm{Ce}, \mathrm{La}, \mathrm{Nd}) \mathrm{PO}_{4} \\
\left.\text { bastnaesite, }(\mathrm{Ce}, \mathrm{La}, \mathrm{Nd})(\mathrm{CO})_{3}\right) \mathrm{F} \\
\text { huanghoite, } \mathrm{Ba}(\mathrm{Ce}, \mathrm{La}, \mathrm{Nd})\left(\mathrm{CO}_{3}\right)_{2} \mathrm{~F} \\
\text { parisite, }(\mathrm{Ce}, \mathrm{La}, \mathrm{Nd})_{2} \mathrm{Ca}\left(\mathrm{CO}_{3}\right)_{3} \mathrm{~F}_{2} \\
\text { cebaite, } \mathrm{Ba}_{3} \mathrm{Ce}_{2}\left(\mathrm{CO}_{3}\right)_{5} \mathrm{~F}_{2}\end{array}$ \\
\hline $\begin{array}{l}\mathrm{Nb}( \pm \text { REE's }) \\
\text { minerals. }\end{array}$ & $\begin{array}{l}\text { columbite, } \mathrm{FeNb}{ }_{2} \mathrm{O}_{6} \\
\text { aeschynite, }(\mathrm{Ce}, \mathrm{Ca}, \mathrm{Fe}, \mathrm{Th})(\mathrm{Ti}, \mathrm{Nb})_{2}(\mathrm{O}, \mathrm{OH})_{6} \\
\text { fergusonite, } \mathrm{YNbO}{ }_{4} \\
\text { fersmite, }(\mathrm{Ca}, \mathrm{Ce}, \mathrm{Na})(\mathrm{Nb}, \mathrm{Ti})_{2}(\mathrm{O}, \mathrm{OH}, \mathrm{F})_{6} \\
\text { pyrochlore, }(\mathrm{Ca}, \mathrm{Na})_{2} \mathrm{Nb}_{2} \mathrm{O}_{6}(\mathrm{OH}, \mathrm{F}) \\
\text { Nb-rutile }\end{array}$ \\
\hline Fe ore minerals & $\begin{array}{l}\text { magnetite } \\
\text { hematite } \\
\text { martite } \\
\text { goethite } \\
\text { ilmenite }\end{array}$ \\
\hline
\end{tabular}

and others, 1993). Wavelength-dispersive X-ray fluorescence spectrometry (WDXRF) was used for analyzing unmineralized and weakly mineralized dolostone marble. Because of the high contents of combined F, Fe, and REE's, inductively coupled plasma-atomic emission spectrometry (ICP-AES) was used for partial analysis of most of the disseminated and banded ores. $\mathrm{BaO}, \mathrm{SrO}, \mathrm{Ce}_{2} \mathrm{O}_{3}, \mathrm{La}_{2} \mathrm{O}_{3}$, $\mathrm{Nd}_{2} \mathrm{O}_{3}$, and $\mathrm{Nb}_{2} \mathrm{O}_{5}$ contents of unmineralized and REE-mineralized $\mathrm{H} 8$ dolostone marble were determined by inductively coupled plasma-mass spectrometry (ICP-MS). Fluorine and chlorine contents of the ores were determined by the ion-selective electrode (ISE) method (Jackson and others, 1987). $\mathrm{CO}_{2}$ content was determined by using coulometric titration (Jackson and others, 1987). The WDXRF and ICP-AES methods of analysis were described by Taggart and others (1987) and Lichte and others (1987), respectively.

Mineral separations for radiometric-isotopic analysis and age determination were made in the laboratories of the Tianjin Geological Research Academy, in Tianjin, and in USGS laboratories in Reston, $\mathrm{Va}$. $\mathrm{K}-\mathrm{Ar}$ and ${ }^{40} \mathrm{Ar} /{ }^{39} \mathrm{Ar}$ ages were determined in USGS laboratories in Menlo Park, Calif. Precise internal isochron mineral ages of monazites and bastnaesites were determined by the ${ }^{232} \mathrm{Th} /{ }^{208} \mathrm{~Pb}$ method in USGS laboratories in Denver, Colo.
Table 1. Continued.

\begin{tabular}{cl}
\hline \multicolumn{1}{c}{ Mineral category } & \multicolumn{1}{c}{ Principal minerals } \\
\hline $\begin{array}{l}\text { Other carbonate } \\
\text { minerals. }\end{array}$ & $\begin{array}{l}\text { benstonite, }(\mathrm{Ca}, \mathrm{Sr})_{6} \mathrm{Ba}_{6} \mathrm{Mg}\left(\mathrm{CO}_{3}\right)_{13} \\
\text { norsethite, } \mathrm{BaMg}\left(\mathrm{CO}_{3}\right)_{2} \\
\text { barytocalcite, } \mathrm{BaCa}\left(\mathrm{CO}_{3}\right)_{2} \\
\text { strontianite, } \mathrm{SrCO}_{3}\end{array}$ \\
$\begin{array}{c}\text { Common gangue and } \\
\text { other minerals. }\end{array}$ & $\begin{array}{l}\text { fluorite } \\
\text { barite }\end{array}$ \\
& $\begin{array}{l}\text { aegirine } \\
\text { magnesio-arfvedsonite } \\
\text { magnesio-riebeckite }\end{array}$ \\
& apatite \\
phlogopite \\
microcline \\
albite \\
bafertisite, $\mathrm{Ba}\left(\mathrm{Fe}, \mathrm{Mn}_{2}\right)_{2} \mathrm{TiSi}_{2} \mathrm{O}_{7}(\mathrm{O}, \mathrm{OH})_{2}$ \\
cerianite, $(\mathrm{Ce}, \mathrm{Th}) \mathrm{O}_{2}$ \\
Sulfide gangue & pyrite \\
minerals. & $\begin{array}{l}\text { pyrrhotite } \\
\text { sphalerite } \\
\text { galena } \\
\text { chalcopyrite }\end{array}$ \\
&
\end{tabular}

\section{HOST ROCKS AND CAP ROCKS OF THE BAYAN OBO ORE DEPOSIT}

The dominant host rock replaced by the Bayan Obo ores is $\mathrm{H} 8$ marble, followed by interbedded quartzite within the $\mathrm{H} 8$ unit, and overlying $\mathrm{H} 9$ biotite schist and albitized biotite schist. The $\mathrm{H} 8$ unit consists chiefly of dolostone marble but has subordinate limestone marble; interbeds of quartzite and feldspathic quartzite are present throughout the unit but are most prevalent in the upper and lower parts. Sparse layers of albitized biotite schist and biotite-rich (minette) lenses also are present. The $\mathrm{H} 8$ unit consists of a simple suite of rock-forming minerals (table 1), of which deformed and stretched ferroan dolomite is dominant in dolostone marble, calcite in limestone marble, and quartz in quartzite. Detrital mineral grains that are present include quartz, apatite, and albite in dolostone marble, apatite being abundant in coarse-grained dolostone marble. Detrital albite grains also occur in feldspathic quartzite, and albite porphyroblasts are found in albitized biotite schist. Scattered prismatic alkali amphiboles of metamorphic origin are present in the dolostone marble, where they are most abundant along foliation planes.

The distribution, sedimentary structures and textures, and recent stable oxygen and carbon isotope data all indi- 


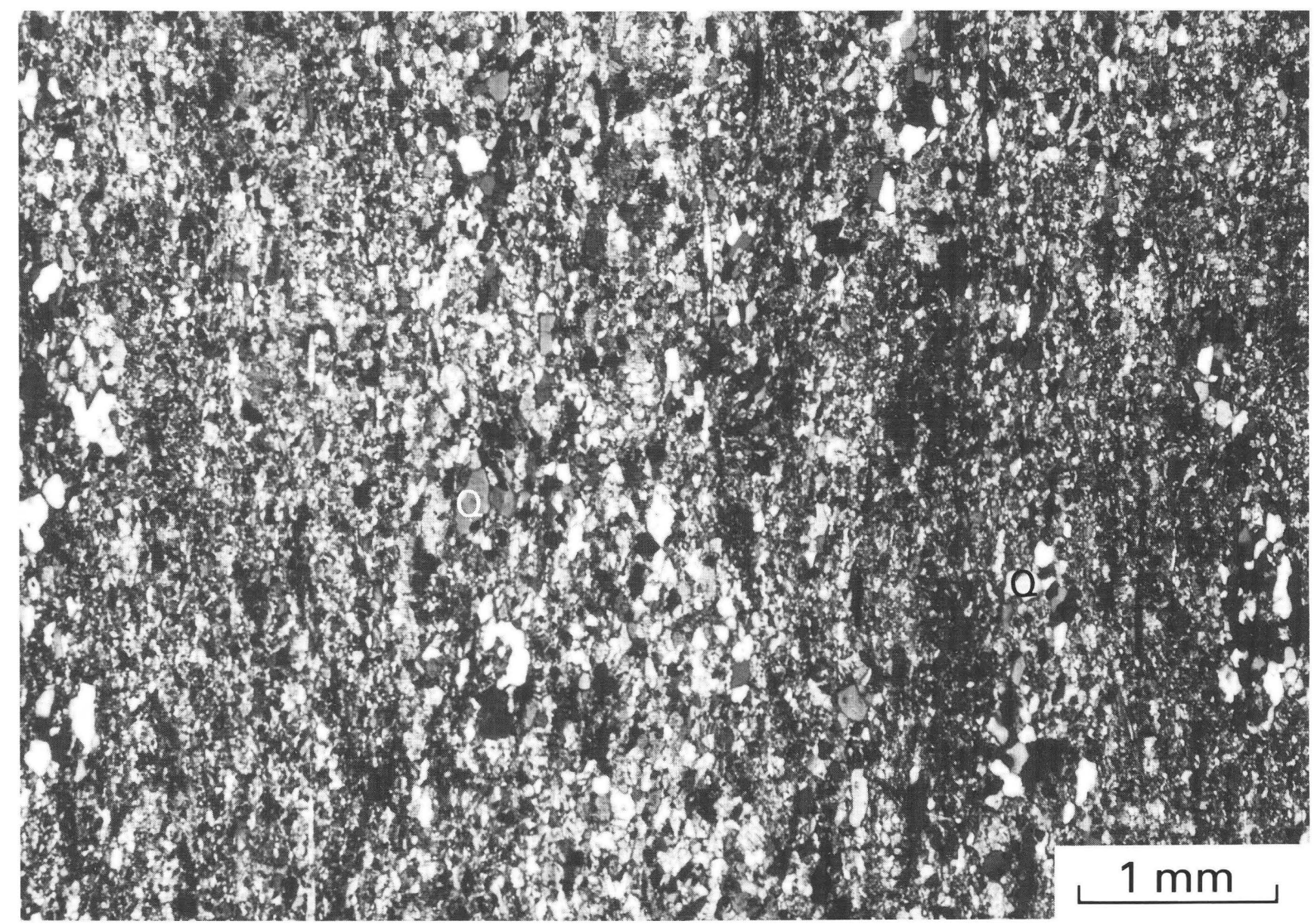

Figure 6. Photomicrograph of sample 7B34, a fine-grained dolostone marble, showing banding parallel to bedding and lenses of scattered detrital quartz grains $(Q)$. (Transmitted light, crossed nicols.) See data for sample 7B34-14 (table 3) for chemical composition of the fine-grained dolostone marble.

cate a sedimentary origin for the $\mathrm{H} 8$ marble unit. Furthermore, the $\mathrm{H} 8$ unit crops out over an area $16 \mathrm{~km}$ long and 2$3 \mathrm{~km}$ wide, an outcrop area much greater than that of any known igneous carbonatite. Although metamorphism has caused intense mylonitization and recrystallization of $\mathrm{H} 8$ carbonate, alternating thick and thin beds of the original sedimentary unit are still evident at many places (Chao and others, 1992). Original sedimentary features such as ripple marks, although rare because of the metamorphic effects, have been observed locally (Meng, 1982), and relict oolitic textures have been reported (Meng and Drew, 1992). Detrital quartz grains are present in the thin-bedded, more finegrained marble (fig. 6), and rounded detrital apatite grains are present in the coarser grained marble (fig. 7). In addition, fossilized blue-green algae and fungal material have been found in the mine region (Meng, 1982). Meng and Drew (1992) reported new data on stable oxygen and carbon isotopes from six selected samples of relict micrite (very fine grained carbonate rock) from the $\mathrm{H} 8$ dolostone marble. One of these samples has a $\delta^{18} \mathrm{O}$ value of 13.9 and a $\delta^{13} \mathrm{C}$ value of -9.27 . The other five samples have $\delta^{18} \mathrm{O}$ values ranging from 16.5 to 21.0 and $\delta^{13} \mathrm{C}$ values from -2.42 to -4.92 . These authors concluded that the relict micrite component of the dolostone samples is of sedimentary origin.

Thin beds of fine-grained to very fine grained highpurity quartzite are present in the $\mathrm{H} 8$ marble unit and locally contain sparse grains of detrital albite feldspar. In thin section, quartzite shows triple-junction grain boundaries; in highly sheared parts, the grains are stretched, having a width-to-length ratio of from 1:5 to more than 1:10. Thin sections also show mortar texture wherein granulated fine-grained quartz occurs between large quartz grains.

Wang and others $(1990,1992)$ and Liu and Wang (1990) reported the presence of small shelly fauna of Early Cambrian age (the Qinghezhen fauna) in the Bayan Obo Group both north and south of the Bayan Obo region. This 


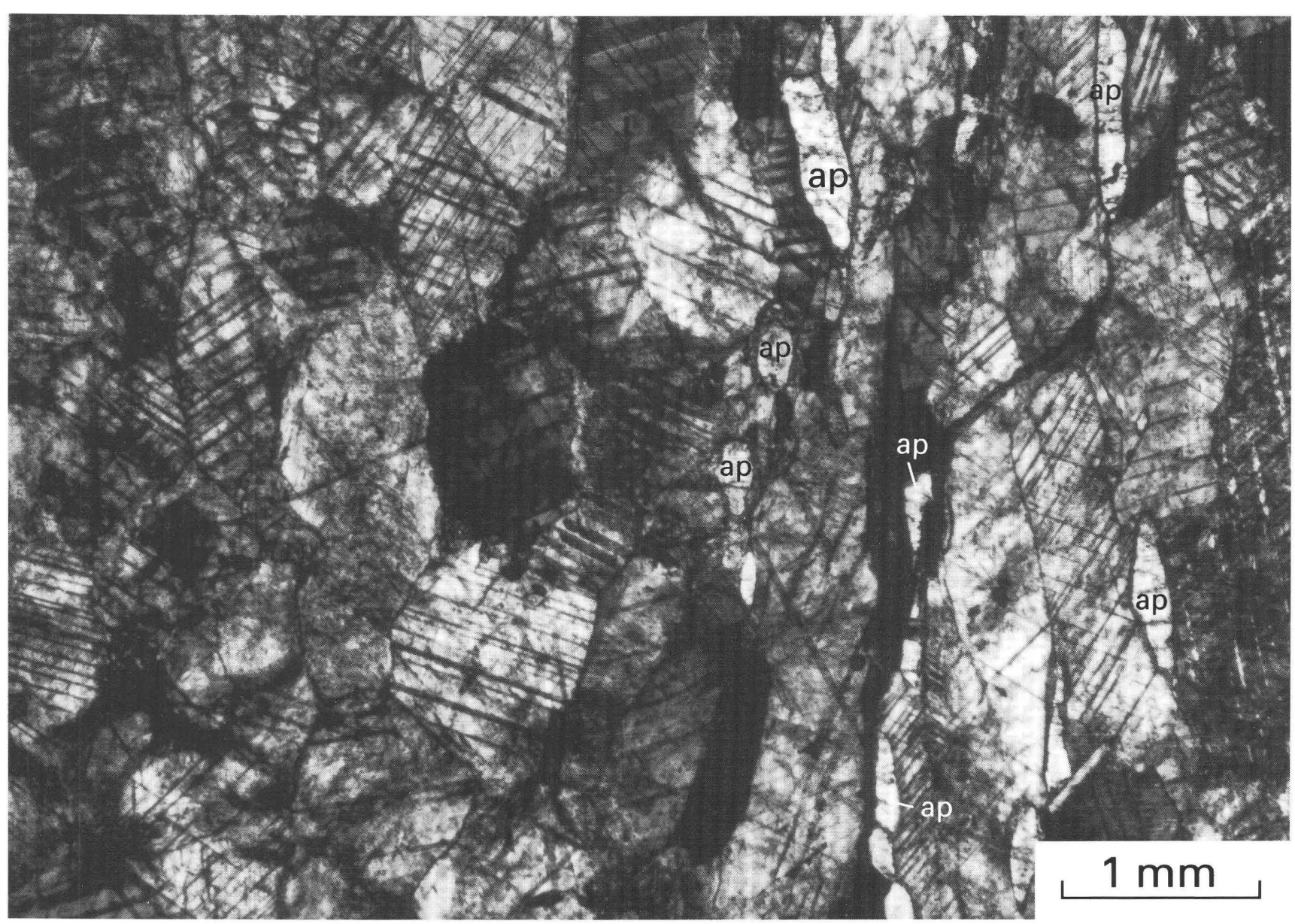

Figure 7. Photomicrograph of sample 7B34-16, a coarse-grained dolostone marble containing rounded grains of detrital apatite (ap) and showing triple-junction grain boundary texture. (Transmitted light, crossed nicols.) For chemical composition, see table 3.

finding implies that the Bayan Obo Group may not be of Precambrian age. However, Li and Zhang (1993) and Zhang (1994) refuted this finding when they reinvestigated the Qinghezhen small shelly fauna and found them to be artificially produced when dilute hydrofluoric acid (HF) was used to extract tubular structures from the carbonate rocks.

A Middle Proterozoic age was attributed to the H1-H9 Bayan Obo Group on the basis of the presence of fossilized blue-green algae and fungal material (Meng, 1982) and on the basis of sequence stratigraphic analysis (Qiao and others, 1991). The significance is questionable of the $\mathrm{Pb}-\mathrm{Pb}$ and Sm-Nd model ages of 1400-1500 Ma that were used by previous investigators to estimate the age of the H8 (Chao and others, 1992; Conrad and McKee, 1992; Wang and others, 1994). The minimum age of the Bayan Obo Group is constrained by a ${ }^{40} \mathrm{Ar} /{ }^{39} \mathrm{Ar}$ age spectrum analysis of alkali amphibole, which is interpreted to reflect an age of $1.26 \mathrm{Ga}$, from a vein cutting the $\mathrm{H} 6$ quartzite (Conrad and McKee, 1992; see also sample Drew 1 in table 15). Alkali amphibole from another vein cutting the $\mathrm{H} 6$ quartzite in the western part of the mine area gave a ${ }^{40} \mathrm{Ar} /{ }^{\beta 9} \mathrm{Ar}$ plateau age of about $820 \mathrm{Ma}$ (Conrad and McKee, 1992; see also sample 7B13C in table 15). A minimum age of the $\mathrm{H} 8$ marble also is indicated by the ${ }^{40} \mathrm{Ar}{ }^{39} \mathrm{Ar}$ ages of alkali amphiboles occurring along foliation planes in the marble, which in spite of varying degrees of argon loss indicated by age spectrum and total fusion analyses (fig. 33), are as old as $890 \mathrm{Ma}$ (samples $40-14$ and $8 \mathrm{~B} 24-1$, table 15). If the dolostone marble is similar in age to the $\mathrm{H} 6$ quartzite, the minimum age of $\mathrm{H} 8$, as well as the entire Bayan Obo Group, is about $1.26 \mathrm{Ga}$, or Middle Proterozoic. By contrast, the earliest age of REE mineralization is $555 \mathrm{Ma}$ (Wang and others, 1994), more than 70 million years (m.y.) younger than the $\mathrm{H} 8$ unit.

On the basis of field and laboratory textural evidence, including an unpublished cathodoluminescence study by Meng Qingrun (unpub. data, 1988), the H8 carbonate rocks were probably deposited as a limestone unit, which was dolomitized after lithification by addition of large quantities of $\mathrm{Mg}$ and $\mathrm{Fe}$ to form the principal mineral, ferroan dolomite. Subsequent regional metamorphism caused myloniti- 
Table 2. Chemical composition (wt. percent) of ferroan dolomite from H8 dolostone marble of Bayan Obo.

[Analysts: J.M. Back and J.A. Minkin. Analysis by electron microprobe analysis (EPMA). Suffixes of sample numbers: C, coarse-grained; F, fine-grained. $<$, less than. For each sample, values represent 5-14 analyses of a total of 5-8 grains. All concentrations were below minimum detection levels (MDL's) for $\mathrm{BaO}$ (MDL 0.09 percent), $\mathrm{Nd}_{2} \mathrm{O}_{3}$ (MDL 0.16 percent), and $\mathrm{Ce}_{2} \mathrm{O}_{3}$ (MDL 0.24 percent). Total $\mathrm{Fe}$ as $\left.\mathrm{FeO}\right]$

\begin{tabular}{|c|c|c|c|c|c|c|c|c|c|c|}
\hline \multirow{2}{*}{ Oxide } & \multicolumn{2}{|c|}{ 7B25-1C } & \multicolumn{2}{|c|}{ 7B36-10C } & \multicolumn{2}{|c|}{ 7B36-10F } & \multicolumn{2}{|c|}{$7 B 34-15 C$} & \multicolumn{2}{|c|}{$7 \mathrm{~B} 34-15 \mathrm{~F}$} \\
\hline & Range & Average & Range & Average & Range & Average & Range & Average & Range & Average \\
\hline MgO & $19.24-19.70$ & 19.41 & $13.78-17.03$ & 15.42 & $16.64-17.54$ & 17.12 & $18.51-19.54$ & 19.01 & 18.15-19.01 & 18.73 \\
\hline $\mathrm{MnO}$ & $.45-.62$ & .55 & $1.67-2.48$ & 2.11 & $1.76-2.46$ & 2.11 & $.65-.87$ & .77 & $.70-.89$ & .80 \\
\hline $\mathrm{FeO}$ & $3.77-4.06$ & 3.90 & $6.17-10.47$ & 8.34 & $5.60-6.26$ & 6.03 & $3.89-5.03$ & 4.45 & $4.35-4.69$ & 4.52 \\
\hline
\end{tabular}

Table 3. Chemical composition (wt. percent) of essentially unmineralized $\mathrm{H} 8$ dolostone marble of Bayan Obo.

[Analysts: J.E. Taggart, A. Bartel, and D. Siems. Analysis by wavelengthdispersive X-ray fluorescence spectrometry (WDXRF) for $\mathrm{SiO}_{2}, \mathrm{Al}_{2} \mathrm{O}_{3}$, total iron as $\mathrm{Fe}_{2} \mathrm{O}_{3}, \mathrm{MgO}, \mathrm{CaO}, \mathrm{Na}_{2} \mathrm{O}, \mathrm{K}_{2} \mathrm{O}, \mathrm{TiO}_{2}, \mathrm{P}_{2} \mathrm{O}_{5}$, and $\mathrm{MnO}$.

Analysts: E. Brandt, C. Papp, and J. Sharkey. Analysis by coulometric titration for $\mathrm{CO}_{2}$ and by ion-selective electrode (ISE) for $\mathrm{Cl}$ and $\mathrm{F}$.

Analyst: P.H. Briggs. Analysis by inductively coupled plasma-mass spectrometry (ICP-MS) for $\mathrm{BaO}, \mathrm{SrO}, \mathrm{Ce}_{2} \mathrm{O}_{3}, \mathrm{La}_{2} \mathrm{O}_{3}, \mathrm{Nd}_{2} \mathrm{O}_{3}$, and $\mathrm{Nb}_{2} \mathrm{O}_{5}$.

*, below minimum detection level (MDL); $\mathrm{MDL}$ for $\mathrm{Al}_{2} \mathrm{O}_{3}=0.10$, $\left.\mathrm{Na}_{2} \mathrm{O}=0.15, \mathrm{~K}_{2} \mathrm{O}=0.02, \mathrm{TiO}_{2}=0.02, \mathrm{Cl}=0.01\right]$

\begin{tabular}{|c|c|c|c|}
\hline \multirow{2}{*}{ Constituent } & \multicolumn{2}{|c|}{ Coarse-grained } & \multirow{2}{*}{$\begin{array}{c}\text { Fine-grained } \\
\text { 7B34-14 }\end{array}$} \\
\hline & 7B25-1 & 7B34-16 & \\
\hline $\begin{array}{l}\mathrm{SiO}_{2} \\
\mathrm{Al}_{2} \mathrm{O}_{3}\end{array}$ & $\begin{array}{l}0.57 \\
*\end{array}$ & $\begin{array}{l}0.46 \\
*\end{array}$ & $\begin{array}{c}5.81 \\
*\end{array}$ \\
\hline${ }^{1} \mathrm{Fe}_{2} \mathrm{O}_{3}$ & 4.56 & 3.97 & 4.41 \\
\hline $\mathrm{MgO}$ & 17.5 & 17.2 & 17.1 \\
\hline $\mathrm{CaO}$ & 31.4 & 32.1 & 28.7 \\
\hline $\mathrm{Na}_{2} \mathrm{O}$ & $*$ & $*$ & $*$ \\
\hline $\mathrm{K}_{2} \mathrm{O}$ & * & .04 & * \\
\hline $\mathrm{TiO}_{2}$ & $*$ & $*$ & * \\
\hline $\mathrm{P}_{2} \mathrm{O}_{5}$ & 1.52 & 3.23 & .31 \\
\hline $\mathrm{MnO}$ & .69 & .62 & .73 \\
\hline $\mathrm{CO}_{2}$ & 44.2 & 43.7 & 43.4 \\
\hline $\mathrm{Cl}$ & $*$ & $*$ & * \\
\hline $\mathrm{F}$ & .10 & .23 & .03 \\
\hline $\mathrm{BaO}$ & .05 & .01 & .02 \\
\hline $\mathrm{SrO}$ & .83 & .63 & .22 \\
\hline $\mathrm{Ce}_{2} \mathrm{O}_{3}$ & .02 & .04 & .46 \\
\hline $\mathrm{La}_{2} \mathrm{O}_{3}$ & .01 & .02 & .26 \\
\hline $\mathrm{Nd}_{2} \mathrm{O}_{3}$ & .01 & .02 & .20 \\
\hline $\mathrm{Nb}_{2} \mathrm{O}_{5}$ & .06 & .21 & $<.01$ \\
\hline Total & 101.52 & 102.48 & 101.66 \\
\hline$-\mathrm{O}=\mathrm{F}$ & 0.04 & 0.10 & 0.01 \\
\hline Total & 101.48 & 102.38 & 101.65 \\
\hline Total $\mathrm{RE}_{2} \mathrm{O}_{3}$ & 0.04 & 0.08 & 0.92 \\
\hline
\end{tabular}

${ }^{1}$ Total $\mathrm{Fe}$ as $\mathrm{Fe}_{2} \mathrm{O}_{3}$. zation and recrystallization of this ferroan dolomite long before mineralization took place.

EPMA of ferroan dolomite from three dolostone marble samples of the $\mathrm{H} 8$ unit is given in table 2. Of these, sample 7B25-1C is coarse-grained dolomite marble; 7B36-10C is coarse-grained ferroan dolomite embedded in a finegrained ferroan dolomite "matrix" (7B36-10F); and 7B34$15 \mathrm{C}$ is coarse-grained ferroan dolomite surrounded by finegrained ferroan dolomite, 7B34-15F, of the same sample. $\mathrm{The} \mathrm{MgO}$ and $\mathrm{FeO}$ contents of both the coarse-grained ferroan dolomite and the fine-grained dolomite are variable, ranging from 13.78 to 19.54 wt. percent $\mathrm{MgO}$ and from 3.77 to 10.47 wt. percent $\mathrm{FeO}$. Textural relations indicate that the fine-grained ferroan dolomite in some of the marble was formed by mylonitization or granulation during regional metamorphism. EPMA indicates that neither the coarse- nor the fine-grained ferroan dolomite was chemically homogenized after recrystallization. It is notable that in a carbonate environment, large quantities of $\mathrm{Fe}$ introduced during dolomitization did not precipitate as primary oolitic $\mathrm{Fe}$ ore of sedimentary origin.

The chemical composition of essentially unmineralized dolostone marble (table 3 ) is an essential parameter for evaluation of a syngenetic versus epigenetic origin of the disseminated REE ores of Bayan Obo. A study of DPTS's of unmineralized dolostone marble (samples 7B25-1 and 7B34-16) from the Bayan Obo mine area shows that the marble contains neither monazite nor bastnaesite. The two samples have essentially the same bulk chemical compositions, and there is variation in the concentration of minor components such as $\mathrm{RE}_{2} \mathrm{O}_{3}$ and $\mathrm{P}_{2} \mathrm{O}_{5}$. The total $\mathrm{RE}_{2} \mathrm{O}_{3}$ and $\mathrm{P}_{2} \mathrm{O}_{5}$ contents of sample 7B34-16 are 0.08 wt. percent $(800$ ppm) and 3.23 wt. percent, respectively, whereas the con- 
Table 4. Chemical composition (wt. percent) of REE-mineralized H8 dolostone marble of Bayan Obo.

[Samples are listed from left to right in order of increasing total $\mathrm{RE}_{2} \mathrm{O}_{3}$ content. Analysts: J.E. Taggart, A. Bartel, and D. Siems. Analysis by wavelength-dispersive X-ray fluorescence spectrometry (WDXRF) for $\mathrm{SiO}_{2}, \mathrm{Al}_{2} \mathrm{O}_{3}$, total iron as $\mathrm{Fe}_{2} \mathrm{O}_{3}, \mathrm{MgO}, \mathrm{CaO}, \mathrm{Na}_{2} \mathrm{O}, \mathrm{K}_{2} \mathrm{O}, \mathrm{TiO}_{2}, \mathrm{P}_{2} \mathrm{O}_{5}$, and $\mathrm{MnO}$.

Analysts: E. Brandt, C. Papp, and J. Sharkey. Analysis by coulometric titration for $\mathrm{CO}_{2}$ and by ion-selective electrode (ISE) for $\mathrm{Cl}$ and $\mathrm{F}$.

Analyst: P.H. Briggs. Analysis by inductively coupled plasma-mass spectrometry (ICP-MS) for $\mathrm{BaO}, \mathrm{SrO}, \mathrm{Ce}_{2} \mathrm{O}_{3}$, $\mathrm{La}_{2} \mathrm{O}_{3}, \mathrm{Nd}_{2} \mathrm{O}_{3}$, and $\mathrm{Nb}_{2} \mathrm{O}_{5}$.

*, below minimum detection level (MDL); $\mathrm{MDL}$ for $\mathrm{Al}_{2} \mathrm{O}_{3}=0.10, \mathrm{Na}_{2} \mathrm{O}=0.15, \mathrm{~K}_{2} \mathrm{O}=0.02, \mathrm{TiO}_{2}=0.02, \mathrm{Cl}=0.01$ ]

\begin{tabular}{|c|c|c|c|c|c|c|}
\hline Constituent & 7B36-10 & 7B34-12 & 7B14-2 & 7B34-10 & 7B36-12 & $7 \mathrm{~B} 36-2$ \\
\hline $\mathrm{SiO}_{2}$ & $*$ & 10.4 & .51 & 1.36 & .20 & .20 \\
\hline $\mathrm{Al}_{2} \mathrm{O}_{3}$ & $*$ & .11 & $*$ & $*$ & $*$ & $*$ \\
\hline${ }^{1} \mathrm{Fe}_{2} \mathrm{O}_{3}$ & 7.60 & 4.97 & 7.38 & 9.12 & 8.30 & 6.87 \\
\hline $\mathrm{MgO}$ & 14.7 & 15.6 & 16.2 & 16.8 & 15.9 & 15.5 \\
\hline $\mathrm{CaO}$ & 30.8 & 26.6 & 26.8 & 29.1 & 28.0 & 27.9 \\
\hline $\mathrm{Na}_{2} \mathrm{O}$ & $*$ & $*$ & $*$ & * & * & $*$ \\
\hline $\mathrm{K}_{2} \mathrm{O}$ & * & .07 & .02 & $*$ & $*$ & $*$ \\
\hline $\mathrm{TiO}_{2}$ & .90 & * & $*$ & $*$ & .39 & .18 \\
\hline $\mathrm{P}_{2} \mathrm{O}_{5}$ & .49 & .88 & 1.04 & 1.09 & .98 & 1.00 \\
\hline MnO & 2.18 & .83 & 1.14 & 1.02 & 2.23 & 1.23 \\
\hline $\mathrm{CO}_{2}$ & 42.3 & 41.5 & 42.5 & 46.1 & 43.7 & 41.2 \\
\hline $\mathrm{Cl}$ & $*$ & $*$ & $*$ & $*$ & $*$ & $*$ \\
\hline $\mathrm{F}$ & 2.15 & .01 & .01 & .02 & .03 & 1.51 \\
\hline $\mathrm{BaO}$ & .36 & .06 & .27 & .01 & .04 & .94 \\
\hline $\mathrm{SrO}$ & .20 & .26 & .38 & .26 & .20 & .25 \\
\hline $\mathrm{Ce}_{2} \mathrm{O}_{3}$ & .55 & .76 & .91 & 1.01 & 1.02 & 2.11 \\
\hline $\mathrm{La}_{2} \mathrm{O}_{3}$ & .28 & .59 & .68 & .82 & .78 & 1.52 \\
\hline $\mathrm{Nd}_{2} \mathrm{O}_{3}$ & .22 & .21 & .24 & .26 & .31 & .57 \\
\hline $\mathrm{Nb}_{2} \mathrm{O}_{5}$ & .21 & .02 & .01 & .02 & .10 & .03 \\
\hline Total & 102.94 & 102.87 & 98.09 & 106.99 & 102.18 & 101.01 \\
\hline$-\mathrm{O}=\mathrm{F}$ & 0.90 & & & 0.01 & 0.01 & 0.64 \\
\hline Total & 102.04 & 102.87 & 98.09 & 106.98 & 102.17 & 100.37 \\
\hline Total $\mathrm{RE}_{2} \mathrm{O}_{3}$ & 1.05 & 1.56 & 1.83 & 2.09 & 2.11 & 4.20 \\
\hline
\end{tabular}

${ }^{1}$ Total $\mathrm{Fe}$ as $\mathrm{Fe}_{2} \mathrm{O}_{3}$.

tents of these constituents in sample 7B25-1 are $0.04 \mathrm{wt}$. percent $(400 \mathrm{ppm})$ and $1.52 \mathrm{wt}$. percent. These values are several times higher than the averages for limestones elsewhere (Bai and Yuan, 1985). Petrographically, coarsegrained dolostone marble such as that of samples 7B25-1 and 7B34-16 contains detrital apatite (fig. 7). It is probable that the small amount of REE's in unmineralized dolostone marble is contained chiefly in the detrital apatite, which possibly had its source in the Archean cratonal landmass. In contrast, sample 7B34-14, a very weakly mineralized dolostone marble that contains extremely fine grained monazite, has 0.76 wt. percent $(7,600 \mathrm{ppm}) \mathrm{RE}_{2} \mathrm{O}_{3}$ and 5.81 wt. percent $\mathrm{SiO}_{2}$. DPTS's show the presence of detrital quartz, which accounts for the high concentration of $\mathrm{SiO}_{2}$, and small elongate aggregates of fine-grained monazite, which account for the $\mathrm{RE}_{2} \mathrm{O}_{3}$ present (table 3).

Throughout the outcrop area (fig. 2), most of the finegrained dolostone marbles of the H8 carbonate unit show at least minor evidence of REE mineralization. In hand specimens of fine-grained dolostone marble, pale yellow streaks indicate the presence of monazite or bastnaesite. Coarsegrained dolostone marble locally also contains disseminated monazite or bastnaesite, but in general, the coarse-grained marble is less fractured, granulated, and mineralized than the fine-grained marble. Table 4 lists six samples of weakly mineralized dolostone marble in which the mineralization consists of increasing amounts of total REE's ranging from 1.05 to 4.20 wt. percent total $\mathrm{RE}_{2} \mathrm{O}_{3}$. Therefore, we conclude that the REE's in unmineralized Bayan Obo dolostone marble are present only in detrital apatite and that $\mathrm{RE}_{2} \mathrm{O}_{3}$ contents greater than about $800 \mathrm{ppm}$ in fine-grained dolostone marble are due to weak epigenetic mineralization. Thus, our findings do not support Bai and Yuan's (1985) conclusion that the unusually high amount of REE's in Bayan Obo carbonate host rocks is of sedimentary-volcanogenic syngenetic origin.

The uppermost H9 unit of the Bayan Obo Group, which is the cap rock of the Bayan Obo orebodies, consists of dark-gray to black shale, slate, biotite schist, and albitized biotite schist. It conformably overlies the H8 marble unit. The least metamorphosed parts of the $\mathrm{H} 9$ unit are black shales that contain detrital quartz and illite, whereas the more intensely metamorphosed $\mathrm{H} 9$ shales now are biotite and albitized biotite schists, which are much more dominant 
in the mine region than the relatively unmetamorphosed shales. Near the Bayan Obo orebodies, chevron folds are prevalent in the $\mathrm{H} 9$ schists, where intercalated boudinage lenses of gray limestone are present. Identification of this carbonate as limestone lenses differs from interpretations by previous workers (Liu, 1986), who considered them to be carbonatite dikes. Mineralized H9 biotite schist locally contains magnetite and REE minerals (Chao and others, 1992).

\section{MINERALOGY OF THE BAYAN OBO OREBODIES}

The Bayan Obo ores are complex, as is indicated by the number of minerals listed, which range from 120 to 174 , according to various reports (Bai and Yuan, 1985; Zhang and Tao, 1986; Institute of Geochemistry, 1988; Chen and others, 1990). These minerals (table 1) consist of both primary and secondary metamorphic minerals of the host rocks and the epigenetic ore and gangue minerals introduced by hydrothermal solutions. Most of the Bayan Obo minerals, particularly in the banded ore, are very fine to extremely fine grained, late-stage minerals; the minerals in veins cutting the previously formed ores are coarser grained. Typically, Bayan Obo hand specimens show a variety of colors that are characteristic of some of the most abundant minerals. Among these are pale-yellow monazite, yellow to brownish-yellow bastnaesite, pale- to dark-blue alkali amphibole, yellow phlogopite, pale-green to green aegirine and aegirine augite, colorless to lavender-purple to darkpurple fluorite, bluish-gray to gray hematite and martite, and dark-gray to black magnetite.

$\mathrm{REE}, \mathrm{Fe}$, and $\mathrm{Nb}$ ore minerals have been identified in the Bayan Obo ores. The most abundant REE minerals are very fine grained monazite and bastnaesite and coarser grained huanghoite (table 1). Fine- to medium-grained bastnaesite also occurs in late-stage ore dominated by aegirine and aegirine augite, where it is associated with apatite and barite. Huanghoite grains generally are larger, up to $2-3 \mathrm{~cm}$ in diameter, and commonly are associated with medium- to coarse-grained aegirine-rich ores. Cordylite $\left(\mathrm{Ba}(\mathrm{Ce}, \mathrm{Nd}, \mathrm{La})_{2}(\mathrm{CO} 3)_{3} \mathrm{~F}_{2}\right)$ is similar to huanghoite in composition (table 1) but differs in usually being very fine grained. Less common REE minerals are parisite and cebaite (table 1). The monazites and bastnaesites of Bayan Obo ores are typically very low in U (less than $5 \mathrm{ppm}$ ) and low in Th (less than 7,000 ppm). Columbite is the most abundant $\mathrm{Nb}$ mineral, and aeschynite, fergusonite, fersmite, and $\mathrm{Nb}$-rutile are common $\mathrm{Nb}$-bearing minerals. Pyrochlore and other $\mathrm{Nb}$ - and REE-bearing minerals such as chevkinite $\left((\mathrm{Ca}, \mathrm{Ce}, \mathrm{Th})_{4}(\mathrm{Fe}, \mathrm{Mg})_{2}(\mathrm{Ti}, \mathrm{Nb}, \mathrm{Fe})_{3} \mathrm{Si}_{4} \mathrm{O}_{22}\right)$ are rare. The most important $\mathrm{Fe}$ minerals in the ores are magnetite, primary fine granular hematite, and martite (pseudomorphs of hematite after euhedral magnetite). Goethite is present in altered zones associated with both primary magnetite- and hema- tite-rich ores. Ilmenite is present locally, particularly in the late-stage banded ores.

Ba-bearing and Sr-bearing carbonate minerals such as benstonite, norsethite, barytocalcite, strontianite, and Sr-calcite (table 1) occur as late-stage minerals replacing carbonate host rocks along grain boundaries. The Ba-bearing carbonate minerals appear to be unrelated to barite, which is one of the most common gangue minerals.

The most widespread gangue minerals are alkali amphiboles (predominantly magnesio-arfvedsonite), fluorite, barite, aegirine augite, phlogopite, apatite, albite, and microcline. Alkali amphiboles provide information about the episodes of hydrothermal activity and regional metamorphism. One of the most distinctive characteristics of alkali amphiboles in Bayan Obo is that they appear to be unrelated to REE mineralization, unlike the amphiboles in carbonatites. Several generations of magnesio-arfvedsonite, and its varied chemical contents of $\mathrm{FeO}, \mathrm{MgO}, \mathrm{MnO}, \mathrm{K}_{2} \mathrm{O}$, and $\mathrm{Na}_{2} \mathrm{O}$, can be distinguished on the basis of textural evidence and ${ }^{40} \mathrm{Ar} /{ }^{39} \mathrm{Ar}$ ages. Magnesio-riebeckite, also present, is more common in veins than magnesio-arfvedsonite and occurs as overgrowths on prismatic magnesioarfvedsonite cores, such as shown in sample 7B34-1.

Fluorite, on the basis of textural relations, usually replaces REE ore minerals such as monazite and bastnaesite and $\mathrm{Fe}$ minerals such as martite and granular hematite. Fluorite and barite commonly replace aegirine in the banded assemblages. Late-stage fluorite and barite also occur as veinlets cutting banded ores.

Aegirine augite replaces host rock dolostone and limestone marble, but more commonly, it occurs together with fluorite in banded ores. Although textural evidence indicates there may be more than one generation of aegirine and aegirine augite, the chemical composition of aegirine augite appears to be fairly uniform (see representative composition in table 5). Because aegirine augite and alkali amphibole usually do not occur in the same mineral assemblage, the time and space of formation of these two minerals were generally unrelated.

Phlogopite, commonly associated with the various generations of alkali amphiboles, replaces host dolostone or limestone marble. Phlogopite and alkali amphiboles partially replaced the host marble as well as the fine-grained monazite and bastnaesite that had previously partially replaced this marble, and were subsequently partially replaced by late-stage unmartitized magnetite.

Medium-grained detrital apatite occurs in coarsegrained $\mathrm{H} 8$ dolostone marble. Fine-grained to very fine grained granular apatite and porphyroblastic apatite of hydrothermal origin generally are associated with small amounts of monazite and granular hematite in banded lowgrade REE ores. The detrital apatite can be distinguished from very fine grained to fine-grained hydrothermal apatite by distribution, origin, and REE content. EPMA and SXRF analyses by Chen and others (1993) indicate that the light 
Table 5. Chemical composition (wt. percent) of huanghoite, apatite, and aegirine augite of Bayan Obo.

[Analysts: J.M. Back and J.A. Minkin. Analysis by electron microprobe analysis (EPMA). —, not analyzed.

*, below minimum detection level (MDL); $\mathrm{MDL}$ for $\mathrm{Pr}_{2} \mathrm{O}_{3}=0.09$, $\mathrm{Y}_{2} \mathrm{O}_{3}=0.07, \quad \mathrm{P}_{2} \mathrm{O}_{5}=0.04, \quad \mathrm{TiO}_{2}=0.04, \quad \mathrm{MnO}=0.04, \quad \mathrm{MgO}=0.06$, and $\left.\mathrm{K}_{2} \mathrm{O}=0.01\right]$

\begin{tabular}{|c|c|c|c|c|}
\hline Constituent & $\begin{array}{c}\text { Huanghoite } \\
\text { 7B40-3 }\end{array}$ & $\begin{array}{l}\text { Apatite } \\
\text { 7B25-1 }\end{array}$ & $\begin{array}{l}\text { Apatite } \\
\text { 7B31-9 }\end{array}$ & $\begin{array}{c}\text { Aegirine } \\
\text { augite } \\
\text { 8B13-12 }\end{array}$ \\
\hline $\mathrm{La}_{2} \mathrm{O}_{3}$ & 7.98 & 0.15 & 0.52 & 一 \\
\hline $\mathrm{BaO}$ & 37.05 & - & - & - \\
\hline $\mathrm{Nd}_{2} \mathrm{O}_{3}$ & 9.12 & .19 & 1.10 & - \\
\hline $\mathrm{Ce}_{2} \mathrm{O}_{3}$ & 23.14 & .35 & 1.46 & - \\
\hline $\mathrm{Pr}_{2} \mathrm{O}_{3}$ & 2.70 & * & .25 & - \\
\hline $\mathrm{Y}_{2} \mathrm{O}_{3}$ & .11 & * & 1.05 & - \\
\hline $\mathrm{CaO}$ & .05 & 53.08 & 49.79 & - \\
\hline $\mathrm{P}_{2} \mathrm{O}_{5}$ & $*$ & 41.35 & 39.56 & - \\
\hline $\mathrm{F}$ & 4.00 & 4.87 & - & - \\
\hline $\mathrm{SiO}_{2}$ & - & - & - & 52.56 \\
\hline $\mathrm{TiO}_{2}$ & - & - & - & * \\
\hline $\mathrm{Al}_{2} \mathrm{O}_{3}$ & - & - & - & .45 \\
\hline${ }^{1} \mathrm{Fe}_{2} \mathrm{O}_{3}$ & 一 & 一 & 一 & 33.67 \\
\hline $\mathrm{MnO}$ & - & - & - & $*$ \\
\hline $\mathrm{MgO}$ & 一 & - & - & * \\
\hline $\mathrm{CaO}$ & 一 & - & - & .15 \\
\hline $\mathrm{Na}_{2} \mathrm{O}$ & - & - & 一 & 13.51 \\
\hline $\mathrm{K}_{2} \mathrm{O}$ & 一 & - & - & $*$ \\
\hline Total & 84.15 & 99.99 & 93.73 & 100.34 \\
\hline$-\mathrm{O}=\mathrm{F}$ & 1.69 & 2.05 & & \\
\hline Total & 82.46 & 97.94 & 93.73 & 100.34 \\
\hline
\end{tabular}

${ }^{1}$ Total $\mathrm{Fe}$ as $\mathrm{Fe}_{2} \mathrm{O}_{3}$.

rare earth element (LREE) concentrations in detrital apatite in coarse-grained dolostone marble sample 7B25-1 are 3-6 times lower than those in hydrothermal apatite in banded ore sample 7B31-9 (table 5).

Albite is widespread, especially as a replacement mineral in the $\mathrm{H} 9$ biotite schist, where albite usually preceded and was replaced by late-stage unmartitized magnetite. Albite also occurs in veinlets in some banded ores and in late-stage albite-hornblende veins cutting $\mathrm{H} 9$ pelitic host rocks. Late-stage $\mathrm{K}$-feldspar, usually microcline, occurs as an isolated accessory gangue mineral in some of the banded ores and is a common metasomatic mineral replacing $\mathrm{H} 9$ biotite schist (Drew and others, 1990).

Bafertisite and cerianite are accessory minerals at Bayan Obo (table 1). Bafertisite typically occurs in aegirine magnetite ores as a prismatic, bright-orange, strongly pleochroic accessory mineral. Cerianite, an alteration product (Zhang and Tao, 1986), is bright red in hand specimen, is red and isotropic in DPTS, and is the only Bayan Obo mineral radioactive enough to require shielding and caution in handling of samples that contain it.
Bayan Obo ores contain only sparse sulfide minerals, principally pyrite, pyrrhotite, sphalerite, galena, and chalcopyrite. Pyrite occurs as scattered disseminated grains in the $\mathrm{H} 8$ carbonate host, commonly associated with disseminated barite and trace amounts of fluorite. Pyrite also occurs as fine stringers and veinlets crosscutting banded ores. The other sulfides are late-stage minerals that occur in some disseminated ores and in small amounts in banded ores.

\section{CLASSIFICATION AND DISTRIBUTION OF ORE TYPES}

There are three broad categories of ore types: disseminated, banded, and massive. The classification of Bayan Obo ores used in this report is based on the classification developed in the early 1960's, which was published by the Institute of Geochemistry (1988) and is, generally, the classification currently used by mine geologists. The classification is based on three principal parameters: (1) field relations and the type of host rock replaced by the ore and gangue minerals, such as $\mathrm{H} 8$ dolostone or limestone marble, quartzite, and $\mathrm{H} 9$ biotite schist and albitized biotite schist; (2) textures and structures, whether the ore minerals are disseminated, banded, or massive; and (3) mineral assemblages; presence or absence of REE minerals, in particular, monazite and bastnaesite; and types of Fe-oxide minerals and dominant gangue minerals. The following accessory minerals, present only in minor amounts, are not included in the classification scheme: barite and Ba-bearing REE minerals such as huanghoite, cordylite, and cebaite; scattered apatite; ilmenite; bafertisite; microcline; pyrite and other sulfides, such as chalcopyrite, sphalerite, and pyrrhotite; $\mathrm{Nb}$-bearing minerals such as columbite, $\mathrm{Nb}$-bearing ilmenorutile, fersmite, aeschynite, and fergusonite; and other rare minerals such as barytocalcite, benstonite, and strontianite. Where relicts of host rock are not observed, the ore classification is based only on textural-structural criteria and mineral assemblages.

The distribution of ore in the Main and the East Orebodies is shown in figure 8 , the outlines of the orebodies being based on average $\mathrm{Fe}$ contents of at least 20 wt. percent. The disseminated dolomite-hosted REE ores, from less than 2 to more than 6 wt. percent total $\mathrm{RE}_{2} \mathrm{O}_{3}$, are distributed generally at or below the footwalls of the Main and East Orebodies and above the hanging wall of the East Orebody (fig. 8). Massive Fe ores, made up of various Fe-oxide minerals, occur in the central parts of both orebodies and are surrounded by banded ores, which are the dominant type of ore in the orebodies. This broad zoning was recognized by mine geologists as early as the 1960's.

The following classification scheme, which is used in this report, includes some ore types that are not mappable units and, therefore, are not delineated in figure 8 . 


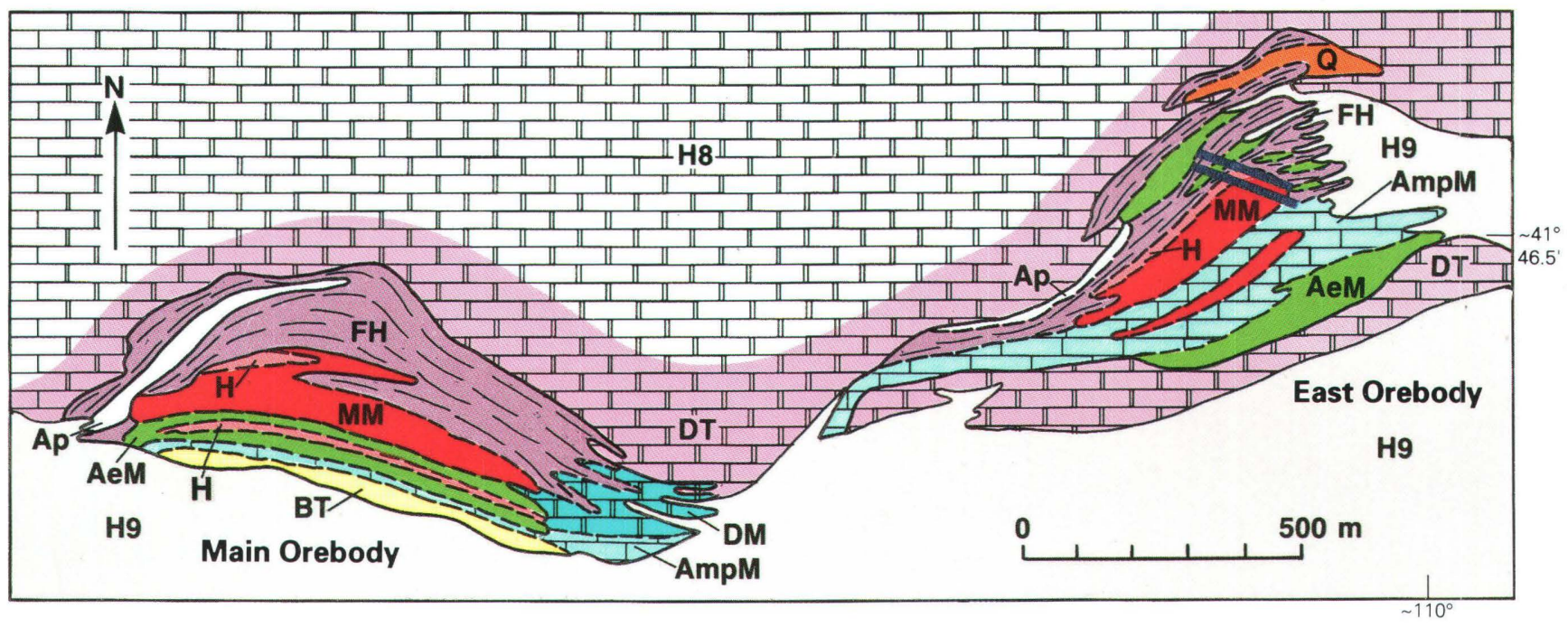

\section{EXPLANATION}

\section{Lithologic Units}

H9 Black shale slate, biotite schist, and albitized biotite schist

"H8 with lenses of quartzite

Disseminated, Banded, and Massive Ores

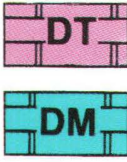

Dolostone marble-hosted REE-martite + magnetite disseminated ore

Dolostone marble-hosted low-grade Fe ore

-FH $\backslash$ REE-hematite + martite-fluorite banded ore

Ap Apatite-hematite-REE banded ore

H Granular hematite-martite massive ore
MM Undifferentiated hematite-martite-magnetite massive ore

AeM Aegirine augite-magnetite banded ore

BT Biotite schist-hosted biotite-magnetite ore

Q Quartzite-hosted ore AmpM Limestone marble-hosted alkali amphibole-
magnetite ore

Dolerite dikes

Boundary of 20 wt. percent Fe

Approximate boundary between ore types

Figure 8. Geologic sketch map of the Main and the East Orebodies of Bayan Obo (modified from Institute of Geochemistry, 1988). 
A. Ores hosted by $\mathrm{H} 8$ dolostone and limestone marble:

1. Disseminated ores:

a. Marble with disseminated monazite only (sample 7B36-6; sample locations are shown in fig. 5 ), with bastnaesite only (samples 34-24, not shown in fig. 5, and 8B7), or with monazite and small amounts of bastnaesite (sample 796$48,278)$. Locally, fluorite is an abundant gangue mineral.

b. Marble with disseminated monazite and magnetite or martitized magnetite (samples B494 89-98, not shown in fig. 5, and 7B36-1B), with or without fluorite.

c. Marble with disseminated granular hematite, with or without small amounts of magnetite (samples 7B36-12 and 9B4), and with or without gangue minerals such as fluorite and barite.

d. Marble with disseminated monazite or bastnaesite and magnetite, and significant amounts of extremely fine grained granular aegirine augite, with or without fluorite (sample 796-48, 459).

e. H8 marble with disseminated monazite, bastnaesite, magnetite, and the gangue minerals phlogopite and alkali amphibole (mainly magnesio-arfvedsonite) (samples 796-48,338 and 796-48,277).

f. H8 limestone marble with disseminated monazite closely associated with significant amounts of extremely fine grained granular apatite, with or without bastnaesite, magnetite, and granular hematite (sample 398-46,305).

2. Banded ores:

a. Monazite ( \pm bastnaesite)-granular hematite-fluorite banded ore (type FH, figs. 8 and 9). This type of banded ore is widespread and consists mainly of varying proportions of alternating submillimeter- to millimeter-thick discontinuous laminae and bands consisting principally of extremely fine grained monazite, extremely fine grained granular hematite, and fluorite. There are many varieties of monazite-hematite-fluorite banded ores.

b. Aegirine augite-magnetite banded ores, with or without varying amounts of monazite or bastnaesite (type AeM, figs. 8 and 10). There are many varieties of this type of banded ore. Where aegirine augite is the dominant gangue mineral, apatite is common, bastnaesite is usually the dominant REE mineral, and martite or magnetite is the dominant $\mathrm{Fe}$ ore mineral.

c. Mixture of types a and b, consisting of monazite, granular hematite, and magnetite, and both aegirine and fluorite as associated gangue minerals (fig. 11). Banded ore that contains both fluorite and aegirine gangue minerals is the most abundant and widespread type of banded ore at the Main and East Orebodies of Bayan Obo. Because this ore type does not occur as a mappable unit, it is incorporated in banded ore types $2 \mathrm{a}(\mathrm{FH})$ and $2 \mathrm{~b}(\mathrm{AeM})$ shown in figure 8 .

d. Monazite-phlogopite-alkali amphibole-magnetite banded ore (type AmpM, fig. 8), with or without fluorite and aegirine augite. This type of banded ore is closely related to the disseminated ore that has a similar mineral assemblage (type 1e).

e. Granular apatite-granular hematite-monazite banded ore (type Ap, figs. 8 and 12) that usually contains fluorite. This ore type, characterized by the presence of granular apatite, is closely related to disseminated ore that has a similar mineral assemblage (type 1f).

3. Massive Fe ores:

Massive $\mathrm{Fe}$ ores consist principally of at least one of the Fe-oxide minerals granular hematite, martite, and magnetite (fig. 13). They represent more intense $\mathrm{Fe}$ mineralization than either disseminated or banded ores. Massive Fe ores occur in H8 carbonate and quartzite hosts and $\mathrm{H} 9$ schist; they also replace banded ores of known or unknown host rocks (samples 7B32-1 and 7B40-2).

B. Ores hosted by $\mathrm{H} 8$ quartzite:

The interbedded quartzite in the $\mathrm{H} 8$ carbonate unit makes up a very minor part of the $\mathrm{H} 8$ and is mineralized only in the Main and East Orebodies, particularly along the footwall of the East Orebody (fig. 8). In spite of the resistance of quartz to chemical alteration, the types of mineralization of quartzite-hosted ores appear similar to those hosted by the $\mathrm{H} 8$ carbonates.

1. Disseminated ores:

The most common quartzite-hosted disseminated ore contains extremely fine grained aegirine augite, bastnaesite, and barite, with or without varying amounts of magnetite (sample 9B18-3c). Some of these ores also contain various amounts of fluorite.

2. Banded ores:

a. Bastnaesite-granular hematite-fluorite banded ore with or without minor granular aegirine (samples 7B30-39, 7B30-40, 7B30-41A, and 7B30-41B). This type of banded ore occurs at the footwall in the northeastern part of the East Orebody (fig. 8).

b. Aegirine-magnetite banded ore, with or without bastnaesite and monazite (sample 7B30-43).

c. Aegirine-fluorite-magnetite ore, with a variety of Ba-bearing REE fluor-carbonate minerals, such as huanghoite and cebaite; barite is common (samples 7B30-47, 9B2-5-1, 9B13-2, 398-46,142). 


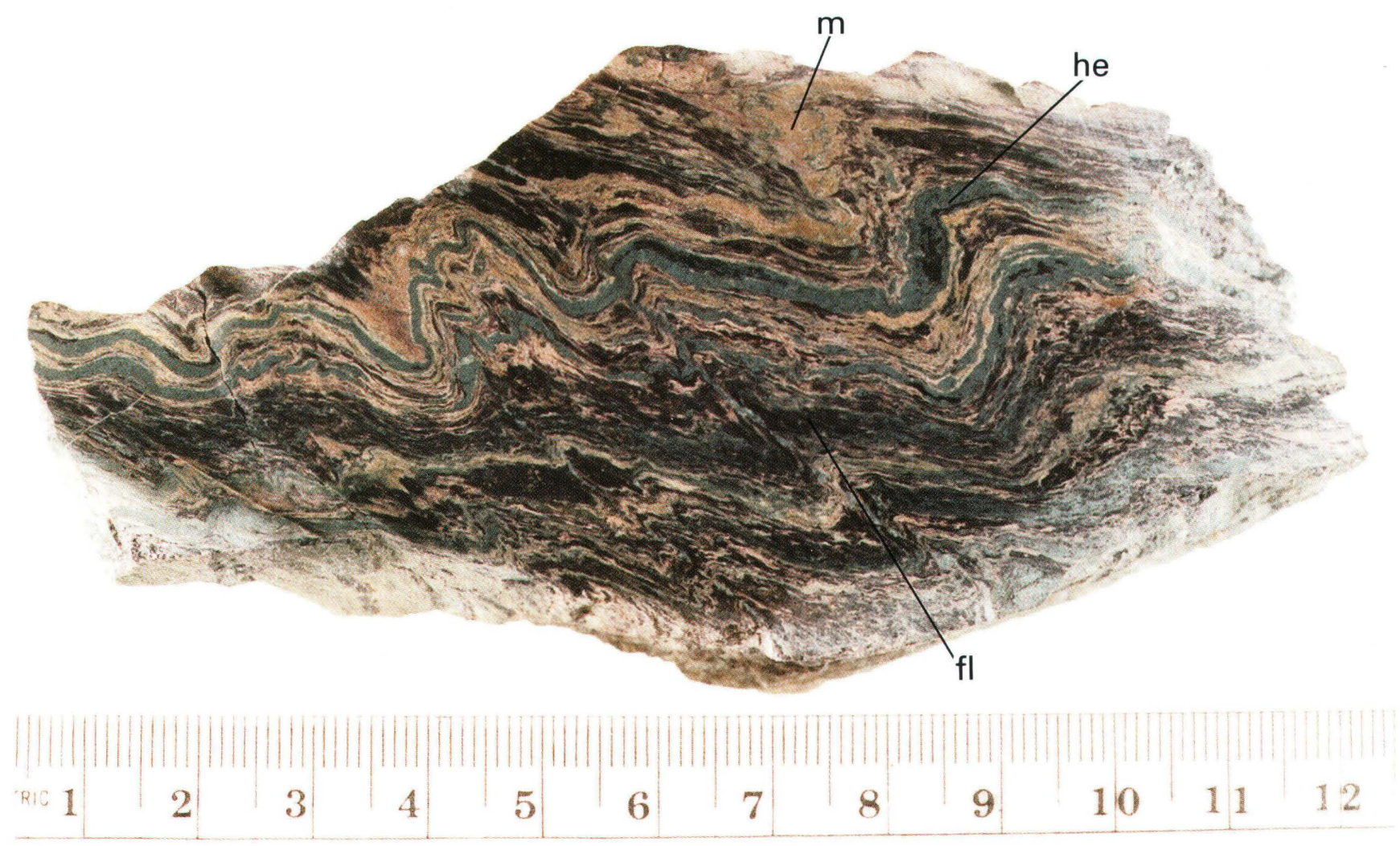

Figure 9. Hand specimen (sample 7B30-1) of typical microfolded banded ore consisting of irregular to lenticular layers of monazite (m), granular hematite (he), and fluorite (fl). Scale is in centimeters. 


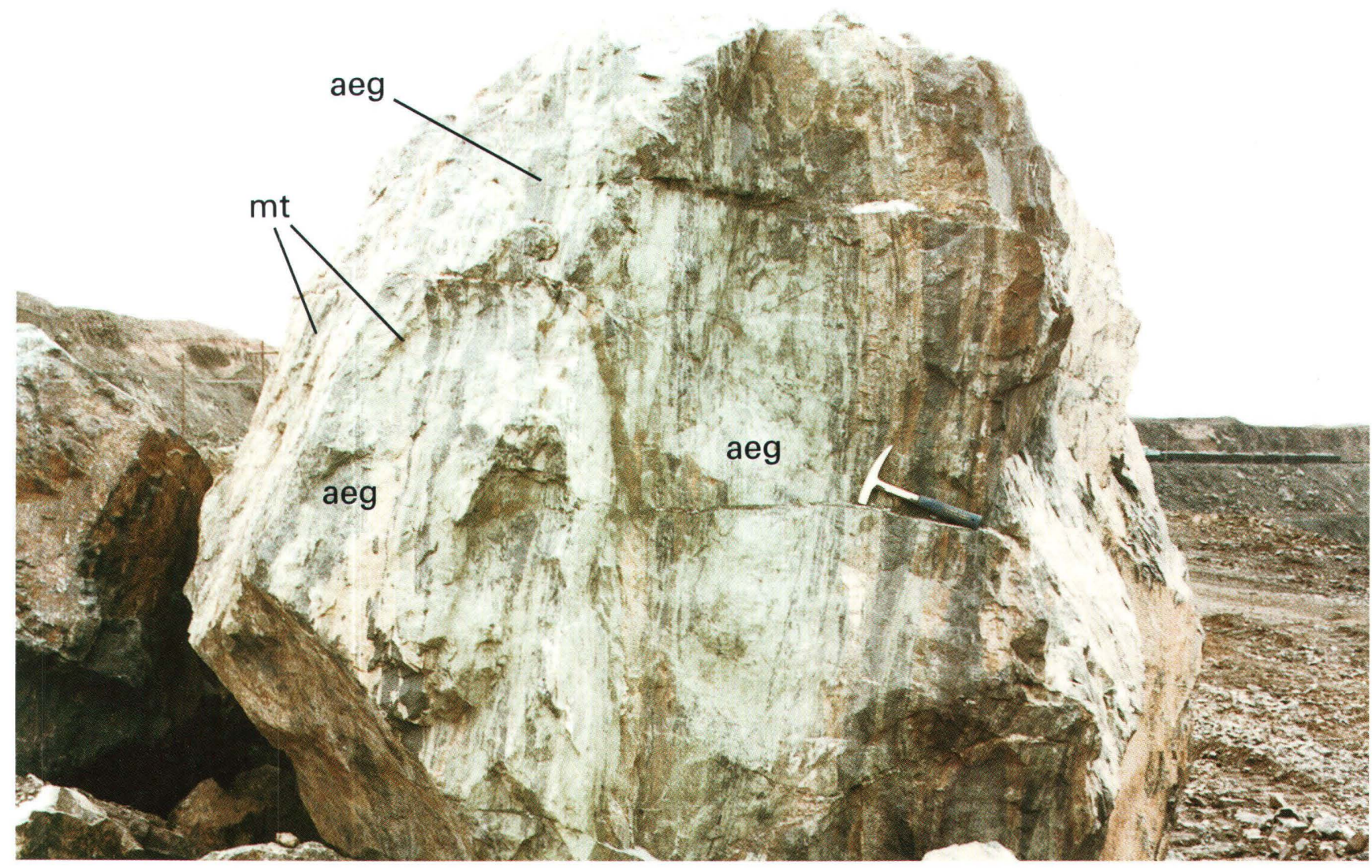

Figure 10. Large block of banded ore consisting of layers of aegirine augite (aeg) and magnetite (mt). Sample 8B13 excavated from bench level $1558 \mathrm{~m}$, at the east end of the East Orebody. 

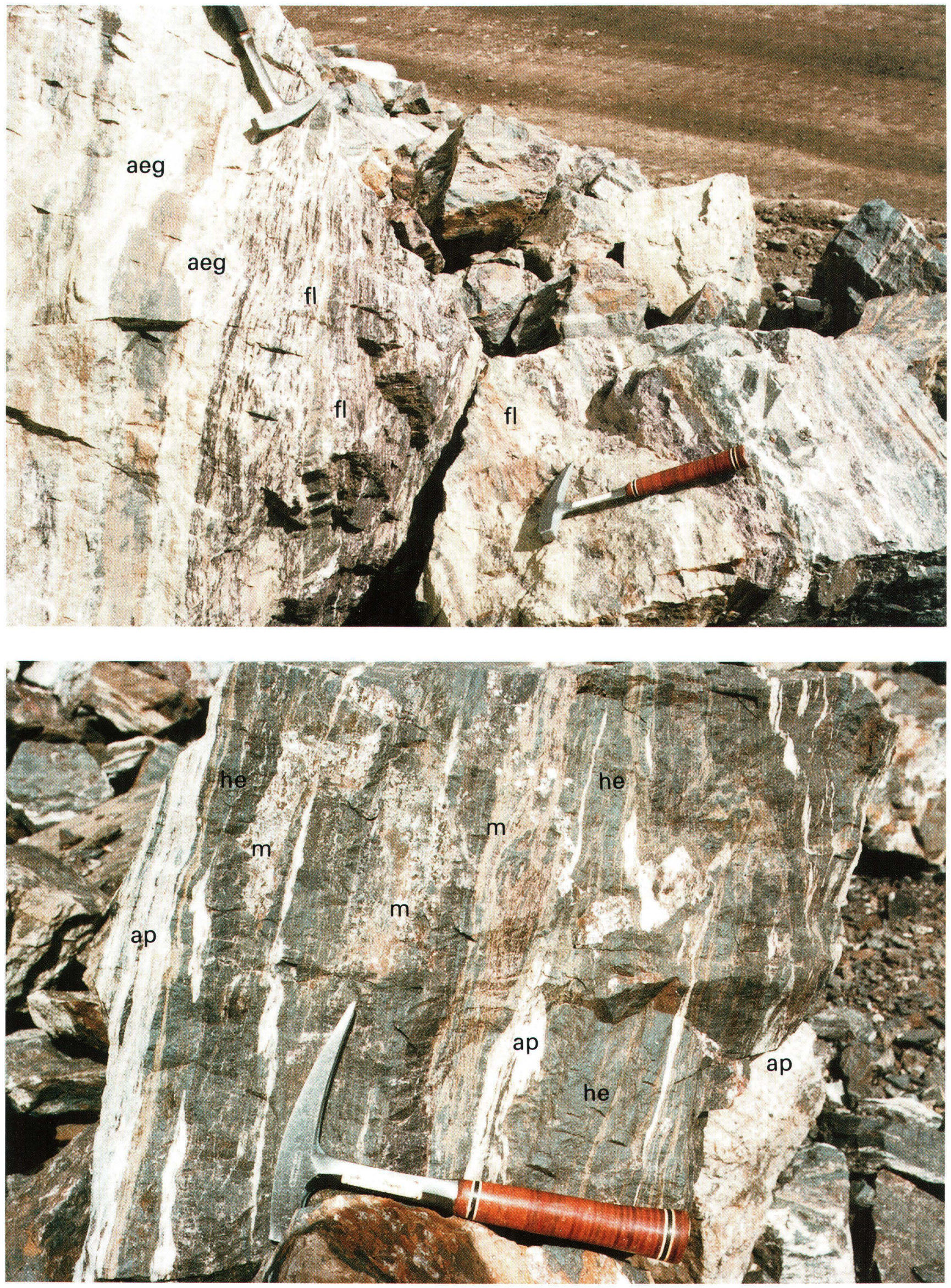
$\leftarrow$ Figure 11. Block (sample 9B3i) showing both fluorite (fl) and aegirine augite (aeg) as major gangue minerals.

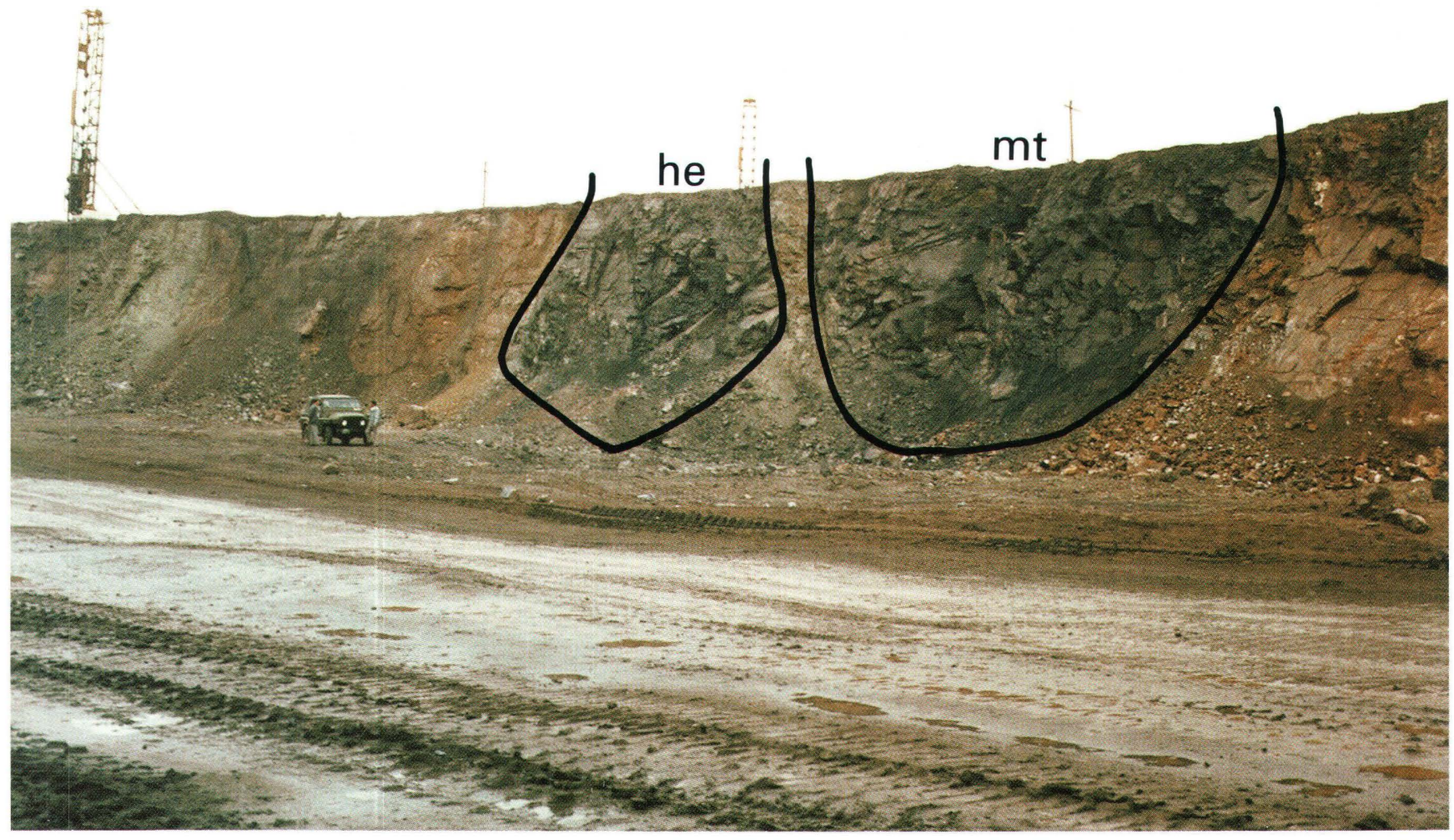

Figure 13. Outcrop on bench $1582 \mathrm{~m}$ of the East Orebody, showing bodies of massive magnetite (mt) and hematite (he) ores. 
d. Granular apatite-granular hematite banded ore, with varying amounts of monazite (samples 9B12a, 8B35-8).

\section{Massive Fe ores:}

Quartzite-hosted massive martite ores with granular hematite contain relict quartz (samples 7B39-4, 398-46,335). Quartzite-hosted massive granular hematite ore is also present, but apparently is not a major ore type.

C. Ores hosted by $\mathrm{H} 9$ biotite schist and albitized biotite schist:

The ores hosted in biotite schist occur only in the hanging wall of the Main Orebody (fig. 8). The most common type of ore in biotite schist is aegirine augitebiotite-magnetite disseminated ore (sample 9B5-2). Locally, small amounts of REE minerals such as cebaite occur in low-grade, disseminated magnetite ores dominated by aegirine augite.

\section{CHEMICAL COMPOSITIONS OF ORES}

Selection of ore types for chemical analysis was based on mineral assemblages. Two different billets of each banded ore sample to be analyzed, each approximately $2-3$ $\mathrm{cm}$ wide, 4-6 cm long, and $0.5 \mathrm{~mm}$ thick, were cut across the banded structure. A DPTS was made from one billet, and the other billet was submitted for chemical analysis (tables 6-12). Two DPTS's (parts A and B) were needed for large samples, which extended for a distance of more than $6 \mathrm{~cm}$ across the bands. Sample locations are shown in figure 5 .

Because of the high contents of combined F, Fe, and REE's in many of the ore types, only partial analyses of ore samples could be obtained by the ICP-AES method, which did not analyze for $\mathrm{SiO}_{2}, \mathrm{Na}_{2} \mathrm{O}, \mathrm{CO}_{2}$, or in most cases, $\mathrm{P}_{2} \mathrm{O}_{5}$; therefore, low analytical totals are reported in tables 6-12. Total $\mathrm{Fe}$ is reported as $\mathrm{Fe}_{2} \mathrm{O}_{3}$ (tables 6-12), because ferric $\mathrm{Fe}$ is the dominant form of $\mathrm{Fe}$ in most of the minerals present. Each sample of ore from a quartzite host has a low total of constituents because $\mathrm{SiO}_{2}$ content was not determined. Similarly, for a sample containing aegirine augite, the total is low because neither $\mathrm{SiO}_{2}$ nor $\mathrm{Na}_{2} \mathrm{O}$ was determined. Because of the heterogeneity and erratic variation of mineral assemblages in bands in banded ores, the chemical composition of an ore is not expected to correlate with the modal mineral composition of the corresponding DPTS. Nevertheless, the general mineral assemblage of the DPTS does reflect the chemical composition qualitatively.

Partial analyses of selected banded ores from Bayan Obo (tables 6-12) are divided on the basis of mineral assemblages from DPTS studies and concentrations of REE's and Fe and are discussed as follows:
1. Dolostone marble having relatively high REE content, and monazite-hematite-apatite banded ores (table 6).

Partial analyses of the chemical compositions of two fractions of a high-grade REE-disseminated ore sample, 7B30-33 (7B30-33A and 7B30-33B, table 6), each having significant amounts of relict host carbonate, show contents of $\mathrm{RE}_{2} \mathrm{O}_{3}$ of 19.56 and 13.23 wt. percent, respectively. Sample 7B30-33A contains more REE's (monazite) and $\mathrm{Fe}$ (granular hematite) and has less fluorite than 7B30-33B. Partial chemical analyses of monazite-hematite-apatite banded ores are also shown in table 6 . The bands of granular apatite visible in the corresponding DPTS's are not reflected in the analyses because $\mathrm{P}_{2} \mathrm{O}_{5}$ concentrations were not determined. Sample $7 \mathrm{~B} 30-27$ contains more $\mathrm{Fe}$ (total $\mathrm{Fe}_{2} \mathrm{O}_{3}$ is 18.6 wt. percent, occurring as granular hematite) and REE's (total $\mathrm{RE}_{2} \mathrm{O}_{3}$ is 8.28 wt. percent) than sample 7B37-3. The $\mathrm{CaO}$ present in both samples is due to apatite and fluorite. The host rock, probably dolostone marble, has been completely replaced by gangue and ore minerals.

2. Monazite ( \pm bastnaesite)-fluorite (low-Fe, high-REE) banded ores (table 7).

The high content of fluorite in the fluorite-type banded ores is indicated by the high $\mathrm{F}$ and $\mathrm{CaO}$ contents in the analyses (table 7). $\mathrm{RE}_{2} \mathrm{O}_{3}$ contents of the seven samples analyzed range from 12.29 to 25.06 wt. percent. Samples 7B31-1A and 7B31-1B from successive bands of the same hand specimen are similar in composition, but the total $\mathrm{RE}_{2} \mathrm{O}_{3}$ content of $7 \mathrm{~B} 31-1 \mathrm{~B}$ (25.06 wt. percent) is appreciably higher than that of 7B31-1A (18.27 wt. percent). The presence of small amounts of $\mathrm{MgO}$ in these samples is probably due to the presence of phlogopite observed in the hand specimen, whereas Fe comes from fine granular aegirine augite and magnetite.

3. Bastnaesite-apatite-aegirine augite-fluorite \pm martite banded ores (table 8 ).

These ores are characterized by the presence of finely granular aegirine augite, in dominant bands, and variable amounts of fluorite. The principal REE mineral is very fine grained to medium-grained bastnaesite. Chemically, aegirine augite and local, sparse martite are reflected by the total $\mathrm{Fe}$ present $\left(\mathrm{Fe}_{2} \mathrm{O}_{3}\right.$ ranges from 6.86 to 20.0 wt. percent), whereas fluorite is reflected by the $\mathrm{Ca}$ and $\mathrm{F}$ contents $(\mathrm{CaO}$ ranges from 2.94 to 37.78 wt. percent and $\mathrm{F}$ ranges from 1.02 to $16.0 \mathrm{wt}$. percent). The total $\mathrm{RE}_{2} \mathrm{O}_{3}$ content ranges from 3.05 to 17.45 wt. percent (table 8).

4. High-Fe, REE, and fluorite banded ores (table 9).

Samples 7B30-28A and 7B30-28B are from the same hand specimen, which consists of bands containing mixtures of magnetite, monazite, bastnaesite, apatite, and fluorite. Magnetite accounts for the total $\mathrm{Fe}$ present (24.31-37.17 wt. percent $\mathrm{Fe}_{2} \mathrm{O}_{3}$ ) in this sample, and monazite and bastnaesite account for the total $\mathrm{RE}_{2} \mathrm{O}_{3}$ 
Table 6. Partial chemical composition (wt. percent) of disseminated monazite ore in dolostone marble and of monazite-hematiteapatite banded ores of Bayan Obo.

[Analyst: P.H. Briggs. Analysis by inductively coupled plasma-atomic emission spectrometry (ICP-AES) for all oxides reported; $\mathrm{SiO}_{2}, \mathrm{Na}_{2} \mathrm{O}$, $\mathrm{P}_{2} \mathrm{O}_{5}$, and $\mathrm{CO}_{2}$ were not determined.

Analysts: J. Sharkey and E. Brandt. Analysis by ion-selective electrode (ISE) for $\mathrm{F}$.

*, below minimum detection level (MDL); $\mathrm{MDL}$ for $\mathrm{Al}_{2} \mathrm{O}_{3}=0.04$, $\mathrm{K}_{2} \mathrm{O}=0.24$, and $\mathrm{TiO}_{2}=0.03$ ]

\begin{tabular}{|c|c|c|c|c|}
\hline \multirow{2}{*}{ Constituent } & \multicolumn{2}{|c|}{$\begin{array}{l}\text { Disseminated monazite ore } \\
\text { in dolostone marble }\end{array}$} & \multicolumn{2}{|c|}{$\begin{array}{l}\text { Monazite-hematite-apatite } \\
\text { banded ores }\end{array}$} \\
\hline & $7 \mathrm{~B} 30-33 \mathrm{~A}$ & $7 B 30-33 B$ & $7 \mathrm{~B} 30-27$ & 7B37-3 \\
\hline $\begin{array}{l}\mathrm{Al}_{2} \mathrm{O}_{3} \\
{ }^{1} \mathrm{Fe}_{2} \mathrm{O}_{3} \\
\mathrm{MgO} \\
\mathrm{CaO} \\
\mathrm{K}_{2} \mathrm{O} \\
\mathrm{TiO}_{2} \\
\mathrm{MnO} \\
\mathrm{F} \\
\mathrm{BaO} \\
\mathrm{Ce}_{2} \mathrm{O}_{3} \\
\mathrm{La}_{2} \mathrm{O}_{3} \\
\mathrm{Nd}_{2} \mathrm{O}_{3} \\
\mathrm{Nb}_{2} \mathrm{O}_{5} \\
\mathrm{SrO} \mathrm{S}^{2}\end{array}$ & $\begin{array}{c}0.13 \\
15.7 \\
5.47 \\
16.79 \\
* \\
* \\
2.58 \\
2.18 \\
.05 \\
9.72 \\
7.04 \\
2.80 \\
.02 \\
.08\end{array}$ & $\begin{array}{c}0.06 \\
9.86 \\
5.80 \\
29.38 \\
* \\
* \\
1.68 \\
7.98 \\
.05 \\
6.68 \\
4.10 \\
2.45 \\
.01 \\
.10\end{array}$ & $\begin{array}{c}* \\
18.6 \\
.03 \\
22.39 \\
* \\
.15 \\
.02 \\
4.38 \\
.02 \\
4.22 \\
2.46 \\
1.63 \\
.05 \\
.10\end{array}$ & $\begin{array}{r}0.32 \\
6.58 \\
.05 \\
33.58 \\
* \\
.05 \\
.04 \\
8.98 \\
1.45 \\
2.22 \\
1.04 \\
1.40 \\
.01 \\
.09\end{array}$ \\
\hline $\begin{array}{l}\text { Total } \\
-\mathrm{O}=\mathrm{F} \\
\text { Total } \\
\text { Total } \mathrm{RE}_{2} \mathrm{O}_{3}\end{array}$ & $\begin{array}{r}62.56 \\
0.92 \\
61.64 \\
19.56\end{array}$ & $\begin{array}{r}68.15 \\
3.36 \\
64.79 \\
13.23\end{array}$ & $\begin{array}{r}54.05 \\
1.84 \\
52.21 \\
8.31\end{array}$ & $\begin{array}{r}55.81 \\
3.78 \\
52.03 \\
4.66\end{array}$ \\
\hline
\end{tabular}

${ }^{1}$ Total $\mathrm{Fe}$ as $\mathrm{Fe}_{2} \mathrm{O}_{3}$.

Table 7. Partial chemical composition (wt. percent) of selected monazite ( \pm bastnaesite)-fluorite (low-Fe, high-REE) banded ores of Bayan Obo.

[Analyst: P.H. Briggs. Analysis by inductively coupled plasma-atomic emission spectrometry (ICP-AES) for all oxides reported; $\mathrm{SiO}_{2}, \mathrm{Na}_{2} \mathrm{O}, \mathrm{P}_{2} \mathrm{O}_{5}$, and $\mathrm{CO}_{2}$ were not determined.

Analysts: J. Sharkey and E. Brandt. Analysis by ion-selective electrode (ISE) for F.

*, below minimum detection level (MDL); $\mathrm{MDL}$ for $\mathrm{K}_{2} \mathrm{O}=0.24, \mathrm{MgO}=0.03$ ]

\begin{tabular}{lccccccr}
\hline Constituent & $7 \mathrm{~B} 30-1$ & $7 \mathrm{~B} 30-11$ & $7 \mathrm{~B} 30-20$ & $7 \mathrm{~B} 30-32$ & $7 \mathrm{~B} 31-1 \mathrm{~A}$ & $7 \mathrm{~B} 31-1 \mathrm{~B}$ & $7 \mathrm{~B} 38-3$ \\
\hline $\mathrm{Al}_{2} \mathrm{O}_{3}$ & 0.13 & 0.08 & 0.06 & 0.36 & 0.66 & 0.40 & .19 \\
$\mathrm{Fe}_{2} \mathrm{O}_{3}$ & 9.29 & 11.72 & 7.72 & 6.15 & 7.58 & 6.01 & 14.3 \\
$\mathrm{MgO}$ & .23 & .08 & $*$ & .55 & 1.11 & .68 & .13 \\
$\mathrm{CaO}$ & 4.57 & 37.78 & 27.98 & 25.18 & 3.78 & 29.38 & 39.18 \\
$\mathrm{~K}_{2} \mathrm{O}$ & $*$ & $*$ & $*$ & $*$ & .36 & $*$ & $*$ \\
$\mathrm{TiO}_{2}$ & .60 & 1.17 & 1.00 & 4.17 & .18 & .12 & .08 \\
$\mathrm{MnO}$ & .03 & .02 & .01 & .23 & .08 & .06 & .01 \\
$\mathrm{~F}$ & 28.0 & 17.6 & 17.0 & 12.8 & 16.8 & 1.8 & 17.2 \\
$\mathrm{BaO}_{\mathrm{Ce}} \mathrm{O}_{3}$ & .30 & .09 & .04 & 7.70 & .11 & .04 & 3.57 \\
$\mathrm{La} \mathrm{O}_{3}$ & 9.49 & 10.42 & 10.66 & 10.54 & 9.37 & 12.88 & 6.32 \\
$\mathrm{Nd}_{2} \mathrm{O}_{3}$ & 5.04 & 5.28 & 4.69 & 6.33 & 5.98 & 8.33 & 4.10 \\
$\mathrm{Nb}_{2} \mathrm{O}_{5}$ & 2.80 & 3.50 & 3.97 & 3.73 & 2.92 & 3.85 & 1.87 \\
$\mathrm{SrO}$ & .30 & .47 & .36 & .33 & .11 & .11 & .02 \\
$\mathrm{Total}^{\mathrm{O}=\mathrm{F}}$ & .09 & .06 & .05 & .18 & .06 & .07 & .10 \\
$\mathrm{Total}$ & 96.87 & 88.27 & 73.54 & 78.25 & 76.10 & 72.73 & 87.07 \\
Total & 11.79 & 7.41 & 7.16 & 5.39 & 7.07 & 4.55 & 7.24 \\
& 85.08 & 80.86 & 66.38 & 72.86 & 69.03 & 68.18 & 79.83 \\
\hline $\mathrm{RE}_{2}$ & 17.33 & 19.20 & 19.32 & 20.60 & 18.27 & 25.06 & 12.29 \\
\hline
\end{tabular}

${ }^{1}$ Total $\mathrm{Fe}$ as $\mathrm{Fe}_{2} \mathrm{O}_{3}$. 
Table 8. Partial chemical composition (wt. percent) of bastnaesite-apatite-aegirine augite-fluorite \pm martite banded ores with apatite \pm barite of Bayan Obo.

[Analysts: J.E. Taggart, A. Bartel, and D. Siems. Analysis by inductively coupled plasma-atomic emission spectrometry (ICP-AES) for all oxides reported; $\mathrm{SiO}_{2}, \mathrm{Na}_{2} \mathrm{O}, \mathrm{P}_{2} \mathrm{O}_{5}$, and $\mathrm{CO}_{2}$ were not determined.

Analysts: J. Sharkey and E. Brandt. Analysis by ion-selective electrode (ISE) for F.

*, below minimum detection level (MDL); $\mathrm{MDL}$ for $\left.\mathrm{K}_{2} \mathrm{O}=0.24\right]$

\begin{tabular}{|c|c|c|c|c|c|c|c|c|}
\hline Constituent & $7 \mathrm{~B} 30-3$ & $7 \mathrm{~B} 30-16 \mathrm{~A}$ & 7B30-16B & $7 \mathrm{~B} 30-25$ & $7 \mathrm{~B} 30-26$ & 7B $30-44$ & $7 \mathrm{~B} 30-45 \mathrm{~A}$ & $7 \mathrm{~B} 30-45 \mathrm{~B}$ \\
\hline $\mathrm{Al}_{2} \mathrm{O}_{3}$ & 0.26 & 0.13 & 0.11 & 0.17 & 0.53 & 0.26 & 0.25 & 1.57 \\
\hline${ }^{1} \mathrm{Fe}_{2} \mathrm{O}_{3}$ & 15.73 & 7.43 & 10.29 & 8.72 & 17.16 & 20.0 & 13.87 & 6.86 \\
\hline $\mathrm{MgO}$ & .08 & .08 & .03 & .07 & .17 & .08 & .07 & .13 \\
\hline $\mathrm{CaO}$ & 10.07 & 37.78 & 32.18 & 27.98 & 2.94 & 18.19 & 27.98 & 33.58 \\
\hline $\mathrm{K}_{2} \mathrm{O}$ & $*$ & $*$ & $*$ & $*$ & $*$ & $*$ & $*$ & .96 \\
\hline $\mathrm{TiO}_{2}$ & .20 & .10 & .05 & .17 & .70 & .12 & .15 & .13 \\
\hline MnÓ & .04 & .04 & .02 & .02 & .03 & .03 & .03 & .01 \\
\hline $\mathbf{F}$ & 1.68 & 16.0 & 13.6 & 16.0 & 1.02 & 10.20 & 14.4 & 15.0 \\
\hline $\mathrm{BaO}$ & 3.24 & 3.01 & 3.13 & 4.35 & 5.69 & 2.01 & 3.80 & 6.48 \\
\hline $\mathrm{Ce}_{2} \mathrm{O}_{3}$ & 8.90 & 4.45 & 6.44 & 4.45 & 6.44 & 1.64 & 5.04 & 3.28 \\
\hline $\mathrm{La}_{2} \mathrm{O}_{3}$ & 5.98 & 2.35 & 4.93 & 1.99 & 3.40 & .82 & 2.23 & 1.41 \\
\hline $\mathrm{Nd}_{2} \mathrm{O}_{3}$ & 2.57 & 1.28 & 1.63 & 1.40 & 1.75 & .59 & 1.40 & .98 \\
\hline $\mathrm{Nb}_{2} \mathrm{O}_{5}$ & .29 & .02 & .02 & .06 & .54 & .01 & .02 & .07 \\
\hline SrO & .28 & .13 & .13 & .18 & .17 & .11 & .10 & .17 \\
\hline Total & 49.32 & 72.80 & 72.56 & 65.56 & 40.54 & 54.06 & 69.34 & 70.63 \\
\hline$-\mathrm{O}=\mathrm{F}$ & 0.71 & 6.74 & 5.73 & 6.74 & 0.93 & 4.29 & 6.06 & 6.32 \\
\hline Total & 48.61 & 66.06 & 66.83 & 58.82 & 40.11 & 49.77 & 63.28 & 64.31 \\
\hline Total $\mathrm{RE}_{2} \mathrm{O}_{3}$ & 17.45 & 8.08 & 13.00 & 7.84 & 11.59 & 3.05 & 8.67 & 5.67 \\
\hline
\end{tabular}

${ }^{1}$ Total $\mathrm{Fe}$ as $\mathrm{Fe}_{2} \mathrm{O}_{3}$.

Table 9. Partial chemical composition (wt. percent) of high-Fe, REE, and fluorite banded ores of Bayan Obo.

[Analyst: P.H. Briggs. Analysis by inductively coupled plasma-atomic emission spectrometry (ICP-AES) for all oxides reported; $\mathrm{SiO}_{2}, \mathrm{Na}_{2} \mathrm{O}$, $\mathrm{P}_{2} \mathrm{O}_{5}$, and $\mathrm{CO}_{2}$ were not determined.

Analysts: J. Sharkey and E. Brandt. Analysis by ion-selective electrode (ISE) for $\mathrm{F}$.

*, below minimum detection level (MDL); $\mathrm{MDL}$ for $\left.\mathrm{K}_{2} \mathrm{O}=0.24\right]$

\begin{tabular}{lrrrr}
\hline Constituent & 7B30-28A & 7B30-28B & $7 \mathrm{~B} 30-37$ & 7B31-14 \\
\hline $\mathrm{Al}_{2} \mathrm{O}_{3}$ & 0.25 & 0.17 & 0.13 & 0.09 \\
$\mathrm{Fe}_{2} \mathrm{O}_{3}$ & 24.31 & 37.17 & 45.75 & 35.7 \\
$\mathrm{MgO}$ & .25 & .25 & .07 & .10 \\
$\mathrm{CaO}$ & 8.40 & 3.92 & 1.32 & 7.70 \\
$\mathrm{~K}_{2} \mathrm{O}$ & $*$ & $*$ & $*$ & $*$ \\
$\mathrm{TiO}_{2}$ & .47 & .23 & .07 & .75 \\
$\mathrm{MnO}$ & .04 & .02 & .02 & .04 \\
$\mathrm{~F}$ & 3.98 & 1.68 & .54 & 4.38 \\
$\mathrm{BaO}$ & 4.24 & 2.79 & 3.91 & .39 \\
$\mathrm{Ce} \mathrm{O}_{3}$ & 11.24 & 5.50 & 1.17 & 9.14 \\
$\mathrm{La} \mathrm{O}_{3}$ & 8.09 & 3.87 & .46 & 6.33 \\
$\mathrm{Nd}_{2} \mathrm{O}_{3}$ & 3.03 & 1.52 & .40 & 2.33 \\
$\mathrm{Nb}_{2} \mathrm{O}_{5}$ & .14 & .05 & .01 & .18 \\
$\mathrm{SrO}$ & .15 & .07 & .03 & .03 \\
$\mathrm{Total}^{\mathrm{O}=\mathrm{F}}$ & 64.59 & 57.24 & 53.88 & 67.16 \\
$\mathrm{Total}$ & 1.68 & 0.71 & 0.23 & 1.84 \\
Total & 62.91 & 56.53 & 53.65 & 65.32 \\
& 22.36 & 10.89 & 2.03 & 17.80 \\
\hline
\end{tabular}

${ }^{1}$ Total $\mathrm{Fe}$ as $\mathrm{Fe}_{2} \mathrm{O}_{3}$.
Table 10. Partial chemical composition (wt. percent) of high$\mathrm{REE}$, low-Fe, and low-F banded ores of Bayan Obo.

[Analyst: P.H. Briggs. Analysis by inductively coupled plasma-atomic emission spectrometry (ICP-AES) for all oxides reported; $\mathrm{SiO}_{2}, \mathrm{Na}_{2} \mathrm{O}$, $\mathrm{P}_{2} \mathrm{O}_{5}$, and $\mathrm{CO}_{2}$ were not determined.

Analysts: J. Sharkey and E. Brandt. Analysis by ion-selective electrode (ISE) for $F$.

*, below minimum detection level (MDL); $\mathrm{MDL}$ for $\mathrm{K}_{2} \mathrm{O}=0.24$; >, greater than]

\begin{tabular}{lrrrr}
\hline Constituent & $7 \mathrm{~B} 31-10$ & $7 \mathrm{~B} 31-19$ & $7 \mathrm{~B} 31-23$ & $7 \mathrm{~B} 37-1$ \\
\hline $\mathrm{Al}_{2} \mathrm{O}_{3}$ & 0.26 & 0.30 & 0.24 & 0.36 \\
$\mathrm{IFe}_{2} \mathrm{O}_{3}$ & 5.00 & 5.71 & 2.14 & 10.01 \\
$\mathrm{MgO}$ & .12 & .45 & .26 & .36 \\
$\mathrm{CaO}$ & 8.67 & 8.12 & 11.61 & 12.73 \\
$\mathrm{~K}_{2} \mathrm{O}$ & $*$ & $*$ & $*$ & $*$ \\
$\mathrm{TiO}_{2}$ & .08 & .15 & .07 & .12 \\
$\mathrm{MnO}$ & .01 & .03 & .02 & .02 \\
$\mathrm{~F}$ & 4.49 & 2.41 & 3.28 & 6.38 \\
$\mathrm{BaO}$ & 2.46 & .54 & .46 & .36 \\
$\mathrm{Ce} \mathrm{O}_{3}$ & 21.08 & $>23.40$ & $>23.40$ & 18.74 \\
$\mathrm{La}_{2} \mathrm{O}_{3}$ & 15.25 & 16.42 & 15.25 & 12.90 \\
$\mathrm{Nd}_{2} \mathrm{O}_{3}$ & 6.42 & 8.28 & 8.05 & 4.78 \\
$\mathrm{Nb}_{2} \mathrm{O}_{5}$ & .53 & .14 & .01 & .13 \\
$\mathrm{SrO}$ & .09 & .07 & .08 & .05 \\
Total & 64.46 & $>66.02$ & $>64.87$ & 66.94 \\
$-\mathrm{O}=\mathrm{F}$ & 1.89 & 1.01 & 1.38 & 2.69 \\
Total & 62.57 & $>65.01$ & $>63.49$ & 64.25 \\
Total $\mathrm{RE}_{2} \mathrm{O}_{3}$ & 42.75 & $>48.10$ & $>46.40$ & 36.42 \\
& & & & \\
\hline
\end{tabular}

${ }^{1}$ Total $\mathrm{Fe}$ as $\mathrm{Fe}_{2} \mathrm{O}_{3}$. 
Table 11. Partial chemical composition (wt. percent) of marblehosted alkali amphibole-magnetite banded ores of Bayan Obo.

[Analyst: P.H. Briggs. Analysis by inductively coupled plasma-atomic emission spectrometry (ICP-AES) for all oxides reported; $\mathrm{SiO}_{2}, \mathrm{Na}_{2} \mathrm{O}$, $\mathrm{P}_{2} \mathrm{O}_{5}$, and $\mathrm{CO}_{2}$ were not determined.

Analysts: J. Sharkey and E. Brandt. Analysis by ion-selective electrode (ISE) for F.

*, below minimum detection level (MDL); $\mathrm{MDL}$ for $\mathrm{TiO}_{2}=0.03$ ]

\begin{tabular}{|c|c|c|c|c|}
\hline Constituent & 7B33-5 & 7 B33-6A & $7 \mathrm{~B} 33-6 \mathrm{~B}$ & 7B33-7 \\
\hline $\begin{array}{l}\mathrm{Al}_{2} \mathrm{O}_{3} \\
{ }^{1} \mathrm{Fe}_{2} \mathrm{O}_{3} \\
\mathrm{MgO} \\
\mathrm{CaO} \\
\mathrm{K}_{2} \mathrm{O} \\
\mathrm{TiO}_{2} \\
\mathrm{MnO} \\
\mathrm{F} \\
\mathrm{BaO} \\
\mathrm{Ce}_{2} \mathrm{O}_{3} \\
\mathrm{La}_{2} \mathrm{O}_{3} \\
\mathrm{Nd}_{2} \mathrm{O}_{3} \\
\mathrm{Nb}_{2} \mathrm{O}_{5} \\
\mathrm{SrO}^{2}\end{array}$ & $\begin{array}{r}0.17 \\
17.16 \\
4.64 \\
20.99 \\
.48 \\
.03 \\
3.49 \\
9.58 \\
.02 \\
2.22 \\
.96 \\
.97 \\
.01 \\
.11\end{array}$ & $\begin{array}{c}0.28 \\
17.16 \\
4.97 \\
19.59 \\
.60 \\
* \\
4.26 \\
9.58 \\
.04 \\
1.76 \\
.83 \\
.76 \\
.01 \\
.13\end{array}$ & $\begin{array}{r}0.36 \\
15.73 \\
5.31 \\
19.59 \\
.72 \\
.03 \\
5.42 \\
7.98 \\
.04 \\
2.46 \\
1.17 \\
.98 \\
.01 \\
.11\end{array}$ & $\begin{array}{r}0.25 \\
24.31 \\
4.81 \\
19.59 \\
.48 \\
.03 \\
3.87 \\
7.18 \\
.03 \\
2.11 \\
.88 \\
.86 \\
.01 \\
.13\end{array}$ \\
\hline $\begin{array}{l}\text { Total } \\
-\mathrm{O}=\mathrm{F} \\
\text { Total } \\
\text { Total } \mathrm{RE}_{2} \mathrm{O}_{3}\end{array}$ & $\begin{array}{r}60.83 \\
4.03 \\
56.80 \\
4.15\end{array}$ & $\begin{array}{r}59.97 \\
4.03 \\
55.94 \\
3.35\end{array}$ & $\begin{array}{r}59.91 \\
3.36 \\
56.55 \\
4.61\end{array}$ & $\begin{array}{r}64.54 \\
3.02 \\
61.52 \\
3.85\end{array}$ \\
\hline
\end{tabular}

${ }^{1}$ Total $\mathrm{Fe}$ as $\mathrm{Fe}_{2} \mathrm{O}_{3}$.

Table 12. Partial chemical composition (wt. percent) of quartzite-hosted ores of Bayan Obo.

[Analyst: P.H. Briggs. Analysis by inductively coupled plasma-atomic emission spectrometry (ICP-AES) for all oxides reported; $\mathrm{SiO}_{2}, \mathrm{Na}_{2} \mathrm{O}, \mathrm{P}_{2} \mathrm{O}_{5}$, and $\mathrm{CO}_{2}$ were not determined.

Analysts: J. Sharkey and E. Brandt. Analysis by ion-selective electrode (ISE) for F.

*, below minimum detection level (MDL); $\mathrm{MDL}$ for $\mathrm{K}_{2} \mathrm{O}=0.24, \mathrm{MgO}=0.03, \mathrm{MnO}=0.01$, and $\mathrm{TiO}_{2}=0.03$ ]

\begin{tabular}{|c|c|c|c|c|c|c|c|c|c|}
\hline Constituent & 7B30-38 & 7B30-39 & $7 \mathrm{~B} 30-41 \mathrm{~A}$ & $7 \mathrm{~B} 30-41 \mathrm{~B}$ & $7 \mathrm{~B} 30-43$ & $7 \mathrm{~B} 30-52 \mathrm{~A}$ & $7 \mathrm{~B} 30-52 \mathrm{~B}$ & $7 \mathrm{~B} 30-53 \mathrm{~A}$ & $7 \mathrm{~B} 30-53 \mathrm{~B}$ \\
\hline $\mathrm{Al}_{2} \mathrm{O}_{3}$ & 0.06 & 0.04 & 0.08 & 0.11 & 0.60 & 0.21 & 1.57 & 0.43 & 0.42 \\
\hline${ }^{1} \mathrm{Fe}_{2} \mathrm{O}_{3}$ & 4.15 & 9.15 & 12.2 & 20.02 & 13.73 & 6.15 & 7.86 & 3.29 & 7.01 \\
\hline $\mathrm{MgO}$ & $*$ & $*$ & * & .07 & 35 & .08 & .12 & .10 & .12 \\
\hline $\mathrm{CaO}$ & 26.58 & 22.38 & 4.34 & 4.76 & 4.20 & 23.79 & 25.19 & 32.18 & 34.98 \\
\hline $\mathrm{K}_{2} \mathrm{O}$ & $*$ & $*$ & $*$ & $*$ & .36 & $*$ & 1.44 & $*$ & $*$ \\
\hline $\mathrm{TiO}_{2}$ & .28 & * & .07 & .10 & .40 & .23 & .38 & .15 & .13 \\
\hline MnŌ & .02 & $*$ & .09 & .37 & .04 & .02 & .03 & .01 & .01 \\
\hline $\mathrm{F}$ & 14.4 & 1.4 & 1.98 & 1.78 & 1.58 & 13.6 & 13.6 & 19.0 & 21.0 \\
\hline $\mathrm{BaO}$ & 3.80 & 1.23 & 5.36 & 2.79 & 2.34 & 4.35 & 2.01 & 6.03 & 6.81 \\
\hline $\mathrm{Ce}_{2} \mathrm{O}_{3}$ & 4.80 & 1.87 & .87 & .94 & 1.99 & 5.86 & 3.98 & 7.96 & 5.39 \\
\hline $\mathrm{La}_{2} \mathrm{O}_{3}$ & 2.81 & 1.04 & .35 & .77 & .55 & 2.58 & 2.23 & 3.99 & 2.81 \\
\hline $\mathrm{Nd}_{2} \mathrm{O}_{3}$ & 1.28 & .44 & .49 & .30 & .92 & 1.63 & 1.11 & 2.22 & 1.52 \\
\hline $\mathrm{Nb}_{2} \mathrm{O}_{5}$ & .02 & .01 & .02 & .02 & .04 & .02 & .02 & .02 & .01 \\
\hline $\mathrm{SrO}$ & .06 & .04 & .04 & .04 & .11 & .22 & .17 & .15 & .14 \\
\hline Total & 58.26 & 46.60 & 25.89 & 32.07 & 27.21 & 58.74 & 59.71 & 75.53 & 80.35 \\
\hline$-\mathrm{O}=\mathrm{F}$ & 6.06 & 4.38 & 0.83 & 0.75 & 0.66 & 5.73 & 5.73 & 8.00 & 8.84 \\
\hline Total & 52.20 & 42.22 & 25.06 & 31.32 & 26.55 & 53.01 & 53.98 & 67.53 & 71.51 \\
\hline Total $\mathrm{RE}_{2} \mathrm{O}_{3}$ & 7.89 & 3.35 & 1.71 & 2.01 & 3.46 & 10.07 & 7.32 & 14.17 & 9.72 \\
\hline
\end{tabular}

${ }^{1}$ Total $\mathrm{Fe}$ as $\mathrm{Fe}_{2} \mathrm{O}_{3}$. 
present (10.89-22.36 wt. percent). The differences in $\mathrm{Fe}$ and REE content between 7B30-28A and 7B30-28B reflect differences in the abundance of Fe versus $\mathrm{REE}$ bands in the samples analyzed. Sample 7B30-37 is a dolostone marble replaced by granular hematite and trace amounts of monazite. Sample 7B31-14 is a banded Fe-REE ore sample containing bands of granular hematite, REE minerals (monazite and bastnaesite), and fluorite. It has 35.7 wt. percent $\mathrm{Fe}_{2} \mathrm{O}_{3}$ and 17.80 wt. percent total $\mathrm{RE}_{2} \mathrm{O}_{3}$.

5. High-REE and low-Fe and low-F banded ores (table 10).

These banded ores consist of prominent bands containing abundant monazite and bastnaesite. Fluorite and other gangue minerals, such as aegirine in 7B31-10 and apatite in 7B31-23 and 7B37-1, may be present. The $\mathrm{RE}_{2} \mathrm{O}_{3}$ contents of the four samples listed in table 10 range from 36.42 to greater than $48.10 \mathrm{wt}$. percent. Although samples having such high REE content are not rare at Bayan Obo, most of the REE ores contain less than 20.0 wt. percent total $\mathrm{RE}_{2} \mathrm{O}_{3}$ (tables 6-9).

6. Marble-hosted alkali amphibole-magnetite banded ores (table 11).

This ore type occurs near or at the hanging wall of the East Orebody (figs. 5 and 8). The ores have rather low (3.35-4.61 wt. percent) total $\mathrm{RE}_{2} \mathrm{O}_{3}$ contents and are characterized by a rather high $\mathrm{MnO}$ content (3.49-5.42 wt. percent) and high $\mathrm{Fe}$ content due to the presence of late-stage magnetite. Fluorite is generally present, as indicated by the 7.18-9.58 wt. percent $F$ in the samples.

7. Quartzite-hosted ores (table 12).

The samples in table 12 are from a mineralized bed of quartzite along the footwall of the northeastern part of the East Orebody (figs. 5 and 8). The total values in table 12 are low because $\mathrm{SiO}_{2}$ contents of the host quartzite and silicate gangue minerals were not determined by the ICP-AES method of analysis. Aegirine augite and fluorite are generally present in varying amounts; alkali amphibole is typically absent from ores where aegirine augite is an essential component. The dominant REE mineral is bastnaesite, but lesser amounts of cebaite also are present.

8. Massive $\mathrm{Fe}$ ores consisting of granular hematite and martite or of magnetite or of mixtures of $\mathrm{Fe}$-oxide minerals.

Although these three ores were not analyzed, according to mine geologists, massive $\mathrm{Fe}$ ores may contain as much as $\mathbf{5 5} \mathrm{wt}$. percent Fe. Most massive Fe ores contain less than 3 wt. percent $\mathrm{RE}_{2} \mathrm{O}_{3}$.

\section{TEXTURAL EVIDENCE FOR THE EPIGENETIC, HYDROTHERMAL, METASOMATIC ORIGIN OF THE BAYAN OBO ORE DEPOSIT}

Multiple lines of evidence are needed in order to determine the origin and the mineral paragenetic sequence of the Bayan Obo ore deposit (Chao and others, 1993). Replacement textures observed in the field and petrographically from DPTS's are the most important criteria, and are aided by corroborative criteria such as chemical compositions and radiometric isotopic ages of various generations of ore and gangue minerals. An absolute mineral paragenetic sequence can be partially established on the basis of absolute ages of episodes of REE mineralization and the unique chemical compositions and isotopic ratios of the different generations of REE minerals. Without the age and compositional data of key ore and gangue minerals, only the relative mineral paragenetic sequence of complex mineral assemblages can be inferred. For this reason, episodes of REE mineralization as a whole are well established, whereas episodes of $\mathrm{Fe}$ and $\mathrm{Nb}$ mineralization are not. On the basis of widespread metasomatic replacement textures, and chemical compositions and radiometric isotopic ages of ore and gangue minerals, the generalized mineral paragenetic sequence of Bayan Obo was determined (table 13).

Only a few examples of textural evidence of metasomatic replacement at Bayan Obo are illustrated here. These are typical or representative features of replacement of host rock (marble, quartzite, and biotite schist) by either an ore or a gangue mineral, as well as later replacement of an earlier replacement mineral.

There is widespread evidence of host dolostone marble replacement by various ore minerals, such as monazite, bastnaesite, martitized magnetite, fine granular hematite, and fresh magnetite. In the field (fig. 14), a block of lightcolored $\mathrm{H} 8$ dolostone marble was partly replaced by disseminated gray magnetite. Typically, the Proterozoic host $\mathrm{H} 8$ dolostone marble was granulated and recrystallized by regional metamorphism before being replaced interstitially by extremely fine grained monazite of Caledonian age (fig. 15).

Also widespread was the metasomatic replacement of host rocks by gangue minerals such as fluorite, aegirine augite, phlogopite, alkali amphibole, fine granular apatite, albite, and microcline. Hydrothermal replacement of marble by fluorite is observed from initial interstitial replacement to the development of bands of fluorite in the host rocks (fig. 16) to terminal stage, where the host dolomite occurs as scattered islands completely surrounded by fluorite. 
Table 13. Generalized mineral paragenetic sequence of Bayan Obo.

1. Deposition of the sedimentary $\mathrm{H} 8$ carbonate rocks interbedded with quartzites, followed by dolomitization.

2. Occurrence of alkali amphibole veins crosscutting the underlying $\mathrm{H} 6$ quartzite. The minimum ${ }^{40} \mathrm{Ar}{ }^{39} \mathrm{Ar}$ age of the alkali amphibole is $1.26 \mathrm{Ga}$ (Conrad and McKee, 1992).

3. Mylonitization, granulation, and recrystallization of the $\mathrm{H} 8$ carbonate into marble with the development and growth of alkali amphiboles due to regional metamorphism. The age of this period of metamorphism, based on the ${ }^{40} \mathrm{Ar} /{ }^{39} \mathrm{Ar}$ modified minimum ages, ranges from 800 to $900 \mathrm{Ma}$. Possibly accompanying the regional metamorphism are hydrothermal alkali amphibole veins with similar ${ }^{40} \mathrm{Ar} /{ }^{39} \mathrm{Ar}$ ages, cutting the underlying $\mathrm{H} 6$ quartzite.

4. Early disseminated high-Nd monazite and bastnaesite mineralization of $\mathrm{H} 8$ marble ( $\mathrm{Th}-\mathrm{Pb}$ internal isochron ages of 555 and $553 \mathrm{Ma})$.

5. Later disseminated high-La, high-Nd bastnaesite and high-La, low-Nd monazite mineralization of $\mathrm{H} 8$ marble (Th- $\mathrm{Pb}$ internal isochron ages of 496,476 , and $474 \mathrm{Ma}$ ).
6. Early martitized magnetite replacement of $\mathrm{H} 8$ dolostone marble with early monazite mineralization and with martitized magnetite replaced later by surrounding monazite.

7. Monazite mineralization in banded ores associated with aegirine augite, fluorite, hematite, and apatite with $\mathrm{Th}-\mathrm{Pb}$ internal isochron mineral ages between 430 and 420 Ma, accompanied by alkali amphiboles in sheared $\mathrm{H} 8$ marble $\left({ }^{40} \mathrm{Ar} /{ }^{39} \mathrm{Ar}\right.$ age of $\left.425 \mathrm{Ma}\right)$.

8. Granular primary fine-grained hematite replacing monazite in hematite-fluorite banded ores (monazite internal isochron age of $423 \mathrm{Ma}$ ).

9. Aegirine augite-rich veins containing huanghoite and aeschynite ( $\mathrm{Th}-\mathrm{Pb}$ mineral-isochron age of $438 \pm 25 \mathrm{Ma}$ ).

10. Fibrous alkali amphibole vein cutting banded ore $\left({ }^{40} \mathrm{Ar} /{ }^{39} \mathrm{Ar}\right.$ plateau age of $396 \pm 6 \mathrm{Ma}$ ).

11. Late-stage magnetite mineralization replacing Mn-rich magnesio-arfvedsonite $\left({ }^{40} \mathrm{Ar} /{ }^{39} \mathrm{Ar}\right.$ age of $\left.343 \pm 3 \mathrm{Ma}\right)$.

12. Hercynian age late-stage $\mathrm{Nb}$ mineralization.

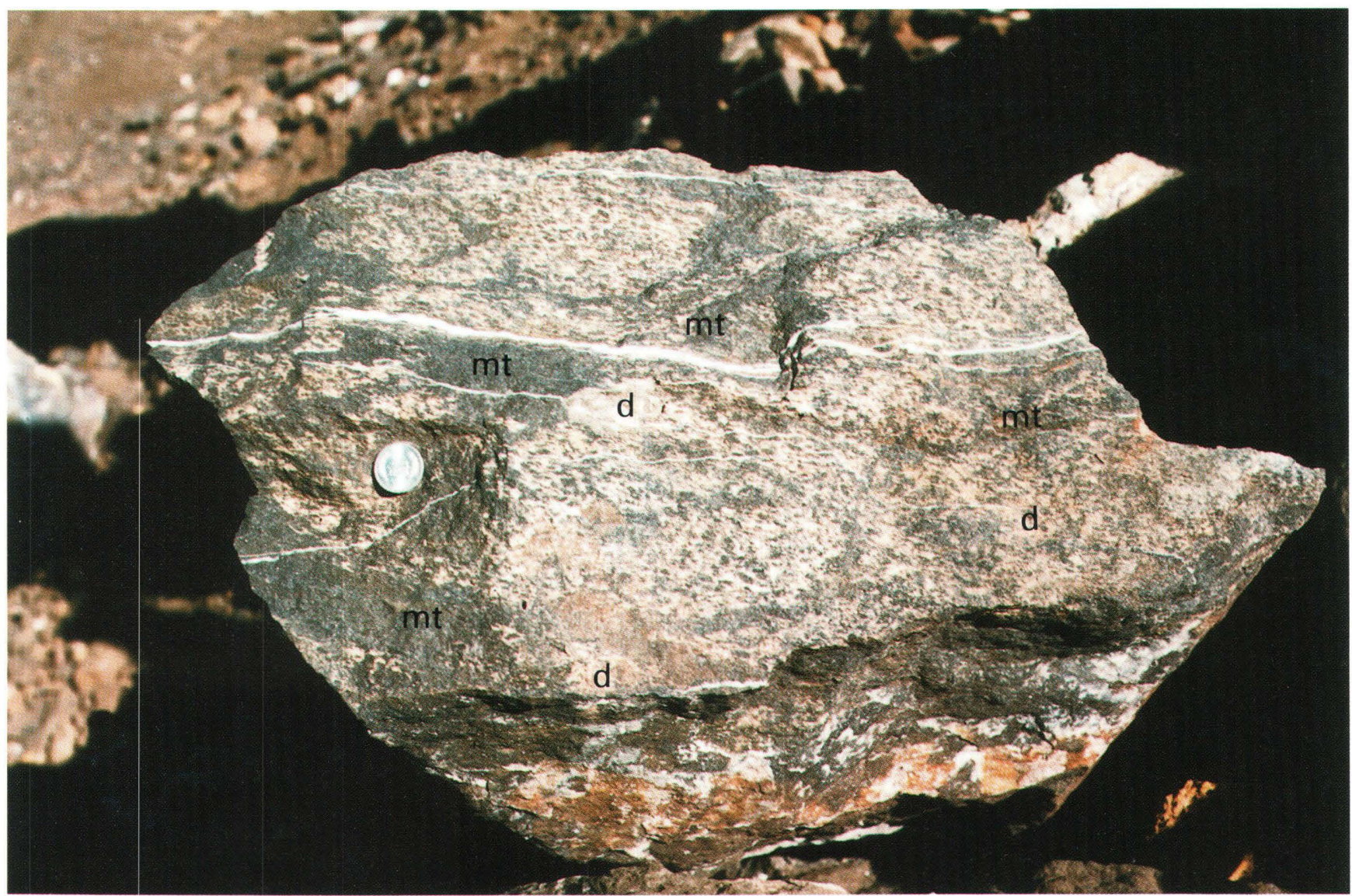

Figure 14. Block of $\mathrm{H} 8$ dolostone marble (d) partly replaced by disseminated magnetite (mt). Scale indicated by $1.8-\mathrm{cm}$ coin. 

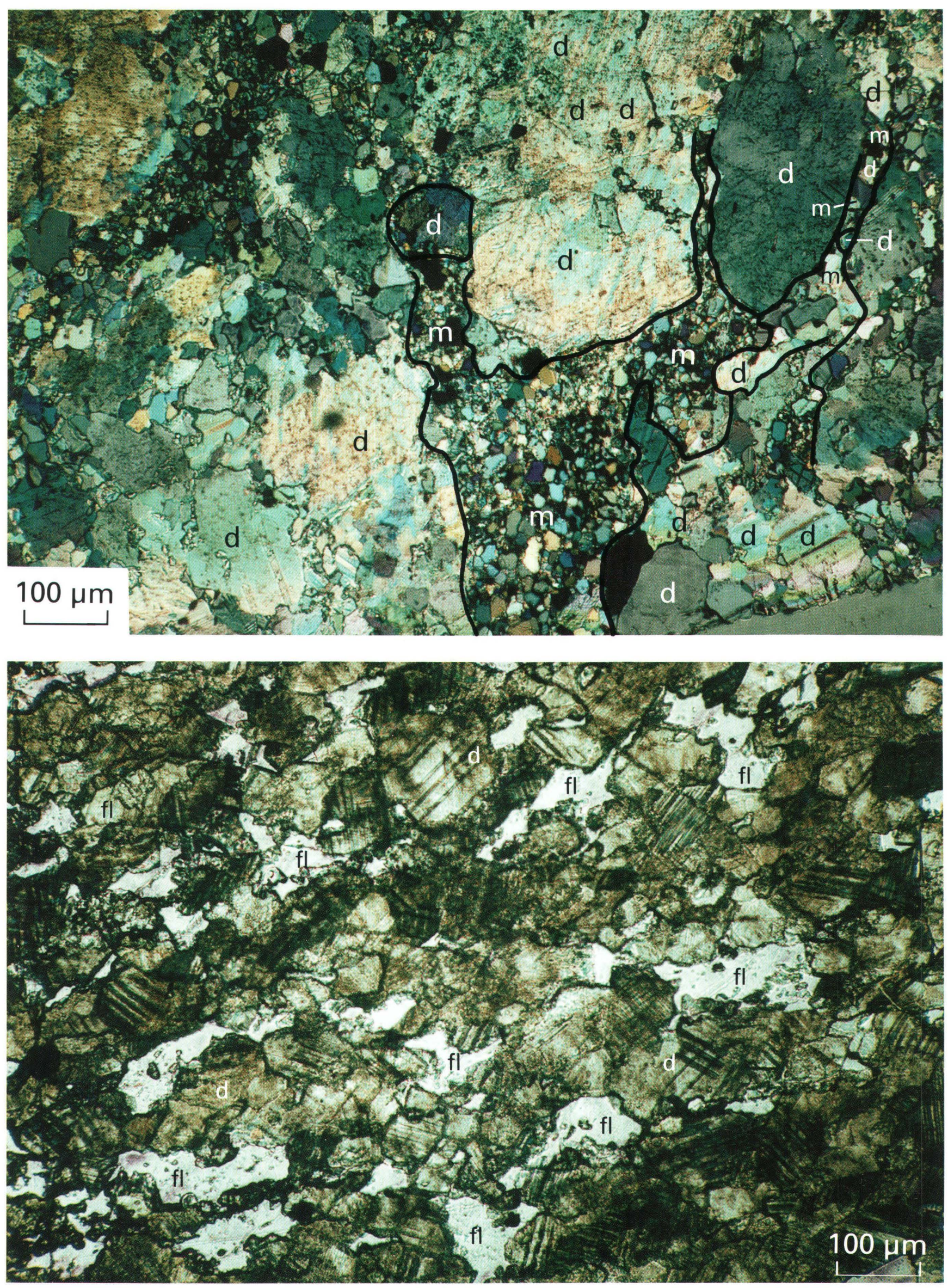
$\leftarrow$ Figure 15. Photomicrograph of a doubly polished thin section (sample 7B36-'90) of the host dolostone marble showing granulation texture and interstitial replacement of granulated grains of dolomite (d) by very fine grained monazite (m). Similar to figure 6 in paper by Chao and others (1992). (Transmitted light, crossed nicols.)

Extremely fine grained aegirine augite similarly replaced host dolomite. Terminal-stage replacement of marble, where relict dolomite grains occur completely surrounded by extremely fine grained aegirine augite, is shown in figure 17.

\section{RADIOMETRIC AGES OF EPISODES OF REE MINERALIZATION AND CHEMICAL COMPOSITIONS OF VARIOUS GENERATIONS OF REE MINERALS}

After more than 2 years of testing, the ${ }^{232} \mathrm{Th} / 208 \mathrm{~Pb}$ internal isochron method was adopted for dating REE minerals (Wang and others, 1994). This method is preferred over other methods because precise ages are obtained on the basis of actual measurements of $\mathrm{Th}$ and $\mathrm{Pb}$, rather than by assuming initial $\mathrm{Pb}$ concentrations. A total of 14 monazite samples and 3 bastnaesite samples were separated from Bayan Obo disseminated and banded ores by the Tianjin Geological Research Academy laboratory in Tianjin and the USGS laboratory in Reston, Va. The purity of single samples of monazite or bastnaesite was then checked by using SEM-EDX in the Reston laboratory before submitting the samples to the USGS laboratory in Denver, Colo., for isotopic determination. Each of the single samples of the REE minerals was further separated into several fractions for isotopic analysis by using a Franz magnetic separator equipped with an alcohol chute (Wang and others, 1994). The results for these 17 samples were described by Wang and others (1994). Two pieces of evidence suggest that the ${ }^{232} \mathrm{Th} /{ }^{208} \mathrm{~Pb}$ data are reliable: (1) all of the monazite and bastnaesite samples submitted yielded good internal isochrons, so that none were rejected; and (2) the internal isochron ages of two splits of monazite sample 796-48,278, submitted 3 months apart to the USGS Denver laboratory, are $422 \pm 16$ and $415 \pm 8 \mathrm{Ma}$, respectively, their combined internal isochron age being $419 \pm 3.7 \mathrm{Ma}$ (fig. 18). Each split of sample $796-48,278$ is represented by five data points. The isotope dilution analyses of the two splits are, respectively, 1,767 and 1,770 ppb total $\mathrm{U}, 2,830$ and 2,449 ppm total Th, and

$\leftarrow$ Figure 16. Photomicrograph of a doubly polished thin section (sample 7B30-2) of banded fluorite dolostone marble showing fluorite (fl) replacement of dolomite (d) at triplejunction grain boundary. (Transmitted light.)
54.26 and $48.96 \mathrm{ppm}$ total $\mathrm{Pb}$. A few internal isochrons are presented here to help illustrate that different generations of monazite and bastnaesite differ not only in their chemical composition and age, but also in initial ${ }^{208} \mathrm{~Pb} /{ }^{204} \mathrm{~Pb}$ ratios, which probably represent different hydrothermal solutions.

Chemical compositions of monazites and bastnaesites were obtained by EPMA, using various calibrated standards. EPMA data on LREE's of monazite and bastnaesite (table 14) are in general agreement with the published average chemical composition of 17 monazite and 22 bastnaesite samples from Bayan Obo, determined by wet chemical methods (Zhang and Tao, 1986, p. 99). EPMA data on REE content of apatites (table 5) are also in good agreement with data obtained by the SXRF method (Chen and others, 1993). Although the 17 REE mineral samples that were dated were also analyzed using INAA for all REE's, including the heavy REE's (HREE's), the INAA data showed significantly lower amounts of LREE's when compared with the EPMA data. Research is in progress to account for this discrepancy. Because the amounts of HREE's are too low to be analyzed by the EPMA method, complete REE distribution curves are not available. EPMA of six of the monazites shows amounts of $\mathrm{Y}_{2} \mathrm{O}_{3}$ ranging from 0.12 to 0.39 wt. percent. Further studies may indicate whether recovery of $\mathrm{Y}$ from this ore deposit is economical.

Concentrations of LREE's ( $\mathrm{La}, \mathrm{Ce}, \mathrm{Nd}$, and Pr), U, Th, and $\mathrm{Pb}$ and initial ${ }^{208} \mathrm{~Pb} /{ }^{204} \mathrm{~Pb}$ ratios constitute the eight chemical parameters used to distinguish monazites and bastnaesites in this study. The chemical compositions and internal isochron ages of monazites and bastnaesites are given in table 14, arranged according to internal isochron ages. The earliest bastnaesite and monazite mineralization in disseminated marble ores occurred at $555 \pm 11 \mathrm{Ma}$ (sample $8 \mathrm{~B} 7$ ) and $553 \pm 16 \mathrm{Ma}$ (sample $7 \mathrm{~B} 36-6$ ), respectively. The bastnaesite sample $8 \mathrm{~B} 7$ (table 14) is characterized by a relatively low $\mathrm{La}_{2} \mathrm{O}_{3}$ content (22.92 wt. percent) and a high $\mathrm{Nd}_{2} \mathrm{O}_{3}$ content (10.53 wt. percent) compared with other dated bastnaesite samples analyzed. The bastnaesite of this generation is also characterized by low $\mathrm{U}, \mathrm{Th}$, and $\mathrm{Pb}$ concentrations, as well as a low initial ${ }^{208} \mathrm{~Pb} /{ }^{204} \mathrm{~Pb}$ ratio. The monazite in sample 7B36-6 is characterized by uniquely low $\mathrm{La}_{2} \mathrm{O}_{3}$ content (13.26 wt. percent), very high $\mathrm{Nd}_{2} \mathrm{O}_{3}$ (11.27 wt. percent), high $\mathrm{Pr}_{2} \mathrm{O}_{3}$ (4.06 wt. percent), extremely high $\mathrm{Ce}_{2} \mathrm{O}_{3}$ (41.55 wt. percent, the highest reported), and a moderately high ${ }^{208} \mathrm{~Pb} / 204 \mathrm{~Pb}$ initial ratio $(39.76 \pm 2.06)$. Disseminated monazite from dolostone marble sample 34-24 (table 14, fig. 19), with an internal isochron age of $532 \pm 3.1$ $\mathrm{Ma}$, is chemically characterized by a moderately low $\mathrm{La}_{2} \mathrm{O}_{3}$ content (17.63 wt. percent), a moderately high $\mathrm{Nd}_{2} \mathrm{O}_{3}$ content $\left(10.80\right.$ wt. percent), and a low ${ }^{208} \mathrm{~Pb} /{ }^{204} \mathrm{~Pb}$ initial ratio (34.89 \pm 0.15$)$.

Bastnaesite from banded ore sample 796-48,280 (table $14)$, with an internal isochron age of $496 \pm 13 \mathrm{Ma}$, is characterized by a high $\mathrm{La}_{2} \mathrm{O}_{3}$ content ( 28.64 wt. percent) and a low $\mathrm{Nd}_{2} \mathrm{O}_{3}$ content $(7.83$ wt. percent). Monazite from 


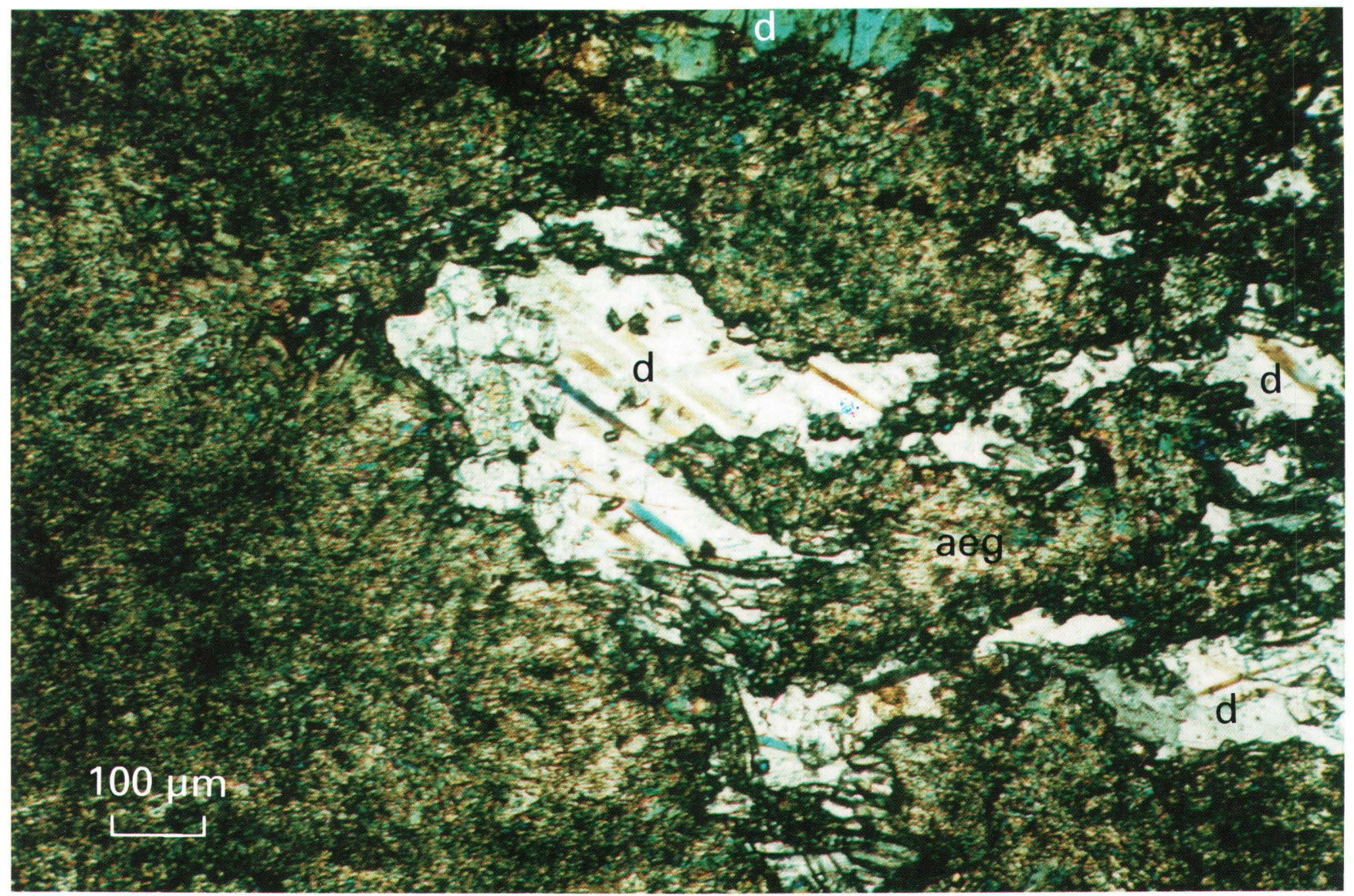

Figure 17. Photomicrograph of a doubly polished thin section (sample 796-48,449) of marble showing relict dolomite (d) grains surrounded by fine granular aegirine augite (aeg) that partially replaced dolomite.

banded monazite-granular hematite-fluorite sample 8B352 , with an internal isochron age of $474 \pm 4.5 \mathrm{Ma}$, is characterized by low $\mathrm{Nd}_{2} \mathrm{O}_{3}$ content ( 8.37 wt. percent), low $\mathrm{Ce}_{2} \mathrm{O}_{3}$ (33.84 wt. percent), relatively high total $\mathrm{U}(3,384 \mathrm{ppb})$, and a moderately high ${ }^{208} \mathrm{~Pb} /{ }^{204} \mathrm{~Pb}$ initial ratio $(40.17 \pm 0.70)$. Disseminated bastnaesite from dolostone marble sample 8510,21-4 (table 14), with an internal isochron mineral age of $475 \pm 8 \mathrm{Ma}$, is chemically characterized by a moderate $\mathrm{La}_{2} \mathrm{O}_{3}$ content ( 24.89 wt. percent), a high $\mathrm{Nd}_{2} \mathrm{O}_{3}$ content (10.90 wt. percent), and an unusually high ${ }^{208} \mathrm{~Pb} /{ }^{204} \mathrm{~Pb}$ initial ratio $(59.83 \pm 5.40)$. Although the monazite from 8 B $35-2$ and bastnaesite from $85-10,21-4$ are nearly identical in their internal isochron age, they probably were not deposited from the same hydrothermal solution because their initial ${ }^{208} \mathrm{~Pb} /{ }^{204} \mathrm{~Pb}$ ratios are very different.

Monazite samples from banded ores of diverse chemical compositions have internal isochron ages ranging from $474 \pm 4.5 \mathrm{Ma}$ (sample 8B35-2, table 14) to $404 \pm 14 \mathrm{Ma}$ (sample 9B9-3, table 14); the peak of REE mineralization of the Bayan Obo ores occurred between 430 and $420 \mathrm{Ma}$. Monazite sample 9B9-3 (table 14), with an internal iso- chron age of $404 \pm 14 \mathrm{Ma}$ (the youngest monazite from banded ores), has the highest total U content of 7,630 ppb. The youngest monazite from marble-hosted disseminated ore sample 12-6A, has an internal isochron age of $398 \pm 9.7$ $\mathrm{Ma}$ and the highest total Th content $(6,071 \mathrm{ppm})$ of all REE samples analyzed. Only two samples, 7B31-2 and 7B31-9 (table 14), are nearly identical with respect to all eight chemical parameters. Samples 796-48,270 and 796-48,278 (table 14) are similar in LREE composition and age, but the large uncertainties regarding the age and ${ }^{208} \mathrm{~Pb} /{ }^{204} \mathrm{~Pb}$ initial ratio for sample 796-48,270 make comparison between these two samples difficult.

The internal isochrons, in ascending order of ${ }^{208} \mathrm{~Pb} /$ ${ }^{204} \mathrm{~Pb}$ initial ratios, for selected samples are shown in figures 19-22. Monazite from sample 490,330 (fig. 19), with an internal isochron mineral age of $431 \pm 2.7 \mathrm{Ma}$, has the lowest ${ }^{208} \mathrm{~Pb} /{ }^{204} \mathrm{~Pb}$ initial ratio $(32.47 \pm 0.17)$ and is the most primitive, least radiogenic sample. Monazite from sample 34-24, with an internal isochron mineral age of $532 \pm 3.1 \mathrm{Ma}$, is the next least radiogenic and has a ${ }^{208} \mathrm{~Pb} /{ }^{204} \mathrm{~Pb}$ initial ratio of $34.89 \pm 0.15$. Monazite from sample 7B36-6 (fig. 20) 


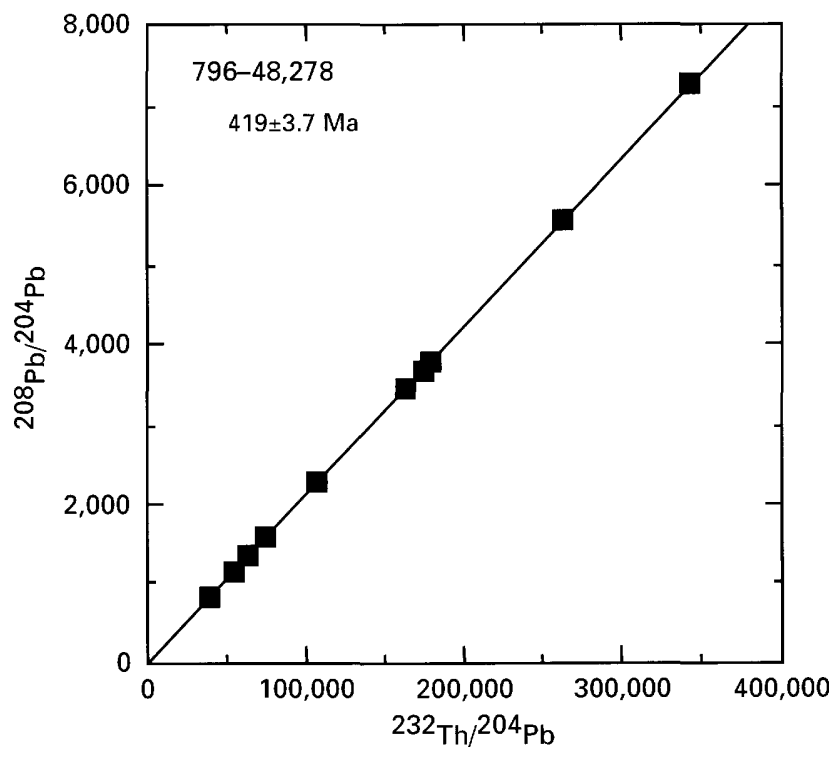

Figure 18. Internal isochron showing mineral age of two aliquots of monazite from sample $796-48,278$. The lower five data points are based on $\mathrm{Th} / \mathrm{Pb}$ isotopic ratios of one aliquot, and the upper points are for the other aliquot.

Table 14. Partial chemical composition and internal isochron mineral ages of monazites ( $m$ ) and bastnaesites (b) of Bayan Obo.

[Ore type: d, disseminated ore; bd, banded ore. *, Age and isotope dilution analyses from Wang and others (1994); analysts: Wang Junwen and M. Tatsumoto. **, determinations by electron microprobe analysis (EPMA); analysts: J.M. Back and J.A. Minkin. RE oxides in weight percent; total U in parts per billion (ppb); Th and $\mathrm{Pb}$ concentrations in parts per million (ppm)]

\begin{tabular}{|c|c|c|c|c|c|c|c|c|c|}
\hline 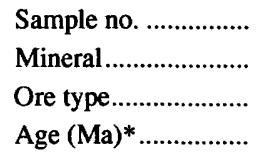 & $\begin{array}{c}8 B 7 \\
b \\
d \\
555 \pm 11\end{array}$ & $\begin{array}{c}7 \mathrm{~B} 36-6 \\
\mathrm{~m} \\
\mathrm{~d} \\
553 \pm 16\end{array}$ & $\begin{array}{c}34-24 \\
\mathrm{~m} \\
\mathrm{~d} \\
532 \pm 3.1\end{array}$ & $\begin{array}{c}796-48,280 \\
\text { b } \\
\text { bd } \\
496 \pm 13\end{array}$ & $\begin{array}{c}8 B 35-2 \\
\text { m } \\
\text { bd } \\
474 \pm 4.5\end{array}$ & $\begin{array}{c}85-10,21-4 \\
\text { b } \\
\text { d } \\
475 \pm 8\end{array}$ & $\begin{array}{c}9 \mathrm{~B} 3-2 \\
\text { m } \\
\text { bd } \\
437 \pm 9.4\end{array}$ & $\begin{array}{c}796-48,277 \\
\text { m } \\
\text { d } \\
432 \pm 8.5\end{array}$ & $\begin{array}{c}490,330 \\
\text { m } \\
\text { bd } \\
431 \pm 2.7\end{array}$ \\
\hline $\begin{array}{l}\mathrm{La}_{2} \mathrm{O}_{3} * * \\
\mathrm{Nd}_{2} \mathrm{O}_{3} * * \\
\mathrm{Ce}_{2} \mathrm{O}_{3} * * \\
\mathrm{Pr}_{2} \mathrm{O}_{3}{ }^{* *} \\
\mathrm{U}(\mathrm{ppb})^{*} \\
\mathrm{Th}(\mathrm{ppm})^{*} \\
\mathrm{~Pb}(\mathrm{ppm})^{*} \\
\text { Initial } \\
\quad{ }_{208} \mathrm{~Pb} /{ }^{204} \mathrm{~Pb}^{*}\end{array}$ & $\begin{array}{c}22.92 \\
10.53 \\
39.11 \\
3.87 \\
55.17 \\
994.2 \\
27.23\end{array}$ & $\begin{array}{c}13.26 \\
11.27 \\
41.55 \\
4.06 \\
506.8 \\
3,670 \\
142.7\end{array}$ & $\begin{array}{c}17.63 \\
10.80 \\
37.38 \\
3.84 \\
559.8 \\
2,678 \\
115.2\end{array}$ & $\begin{array}{c}28.64 \\
7.83 \\
36.37 \\
2.96 \\
853.1 \\
1,284 \\
29.60\end{array}$ & $\begin{array}{c}25.41 \\
8.37 \\
33.84 \\
2.72 \\
3,384 \\
808.6 \\
29.06\end{array}$ & $\begin{array}{c}24.89 \\
10.90 \\
36.24 \\
3.48 \\
236.7 \\
563.6 \\
15.61\end{array}$ & $\begin{array}{c}23.51 \\
8.22 \\
34.65 \\
2.94 \\
449.7 \\
1,202 \\
68.37\end{array}$ & $\begin{array}{c}18.60 \\
10.03 \\
36.91 \\
3.40 \\
321.2 \\
2,988 \\
60.98 \\
61.47 \pm 30.26\end{array}$ & $\begin{array}{r}24.76 \\
7.45 \\
35.25 \\
2.80 \\
201.7 \\
1,102 \\
32.42 \\
32.47 \pm 0.17\end{array}$ \\
\hline 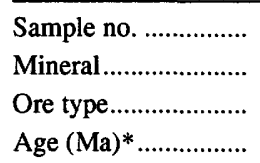 & $\begin{array}{c}7 B 31-23 \\
m \\
\text { bd } \\
429 \pm 11\end{array}$ & $\begin{array}{c}7 B 31-2 \\
m \\
\text { bd } \\
424 \pm 5.6\end{array}$ & $\begin{array}{c}\text { 7B31-9 } \\
\text { m } \\
\text { bd } \\
418 \pm 11\end{array}$ & $\begin{array}{c}\text { 7B30-20 } \\
\text { m } \\
\text { bd } \\
421 \pm 3.3\end{array}$ & $\begin{array}{c}796-48,278 \\
\mathrm{~m} \\
\mathrm{~d} \\
419 \pm 3.7\end{array}$ & $\begin{array}{c}796-48,270 \\
m \\
\text { bd } \\
415 \pm 17\end{array}$ & $\begin{array}{c}9 B 9-3 \\
\mathrm{~m} \\
\text { bd } \\
404 \pm 14\end{array}$ & $\begin{array}{c}12-6 \mathrm{~A} \\
\mathrm{~m} \\
\mathrm{~d} \\
398 \pm 9.7\end{array}$ & \\
\hline $\begin{array}{l}\mathrm{La}_{2} \mathrm{O}_{3} * * \\
\mathrm{Nd}_{2} \mathrm{O}_{3} * * \\
\mathrm{Ce}_{2} \mathrm{O}_{3} * * \\
\mathrm{Pr}_{2} \mathrm{O}_{3} * * \\
\mathrm{U}(\mathrm{ppb})^{*} \\
\mathrm{Th}(\mathrm{ppm})^{*} \\
\mathrm{~Pb} \text { (ppm)* }\end{array}$ & $\begin{array}{c}19.69 \\
10.98 \\
35.95 \\
3.58 \\
313.9 \\
787.2 \\
28.34\end{array}$ & $\begin{array}{r}23.77 \\
9.13 \\
33.92 \\
3.20 \\
5,233 \\
832.2 \\
139.2\end{array}$ & $\begin{array}{c}22.89 \\
9.54 \\
34.63 \\
2.90 \\
3,617 \\
803.8 \\
34.95\end{array}$ & $\begin{array}{c}13.60 \\
13.61 \\
38.69 \\
4.32 \\
461.3 \\
2,417 \\
55.54\end{array}$ & $\begin{array}{c}20.10 \\
10.31 \\
36.12 \\
3.45 \\
1,768 \\
2,657 \\
51.86\end{array}$ & $\begin{array}{c}20.17 \\
9.63 \\
37.42 \\
3.32 \\
340.7 \\
2,273 \\
43.44\end{array}$ & $\begin{array}{c}19.81 \\
10.88 \\
34.96 \\
3.18 \\
7,630 \\
2,012 \\
50.82\end{array}$ & $\begin{array}{c}17.07 \\
12.85 \\
35.84 \\
3.98 \\
3,196 \\
6,071 \\
194.8\end{array}$ & \\
\hline
\end{tabular}

\footnotetext{
${ }^{208} \mathrm{~Pb} /{ }^{204} \mathrm{~Pb}^{*} \quad 47.31 \pm 10.12 \quad 44.97 \pm 0.48 \quad 45.40 \pm 1.30 \quad 66.65 \pm 5.32 \quad 35.49 \pm 10.17 \quad 39.61 \pm 99.27 \quad 41.13 \pm 18.3 \quad 41.67 \pm 1.32$
} 

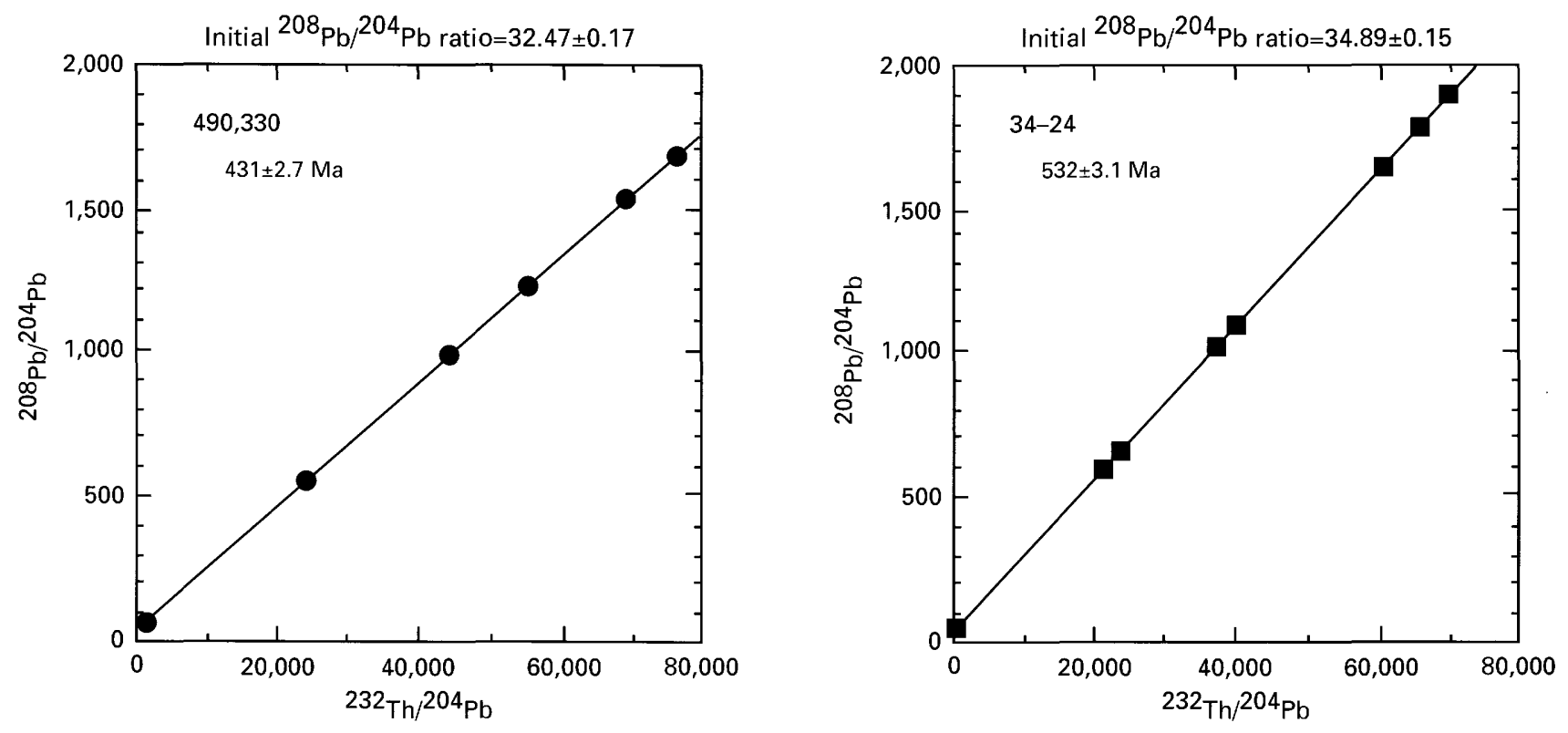

Figure 19. Internal isochrons of monazite from two samples (490,330 and 34-24) of Bayan Obo ores showing ages and ${ }^{208} \mathrm{~Pb} /{ }^{204} \mathrm{~Pb}$ initial ratios. These monazites of different ages have the most primitive nonradiogenic ${ }^{208} \mathrm{~Pb} /{ }^{204} \mathrm{~Pb}$ initial ratios of all $\mathrm{Bayan} \mathrm{Obo}$ ores we have tested.
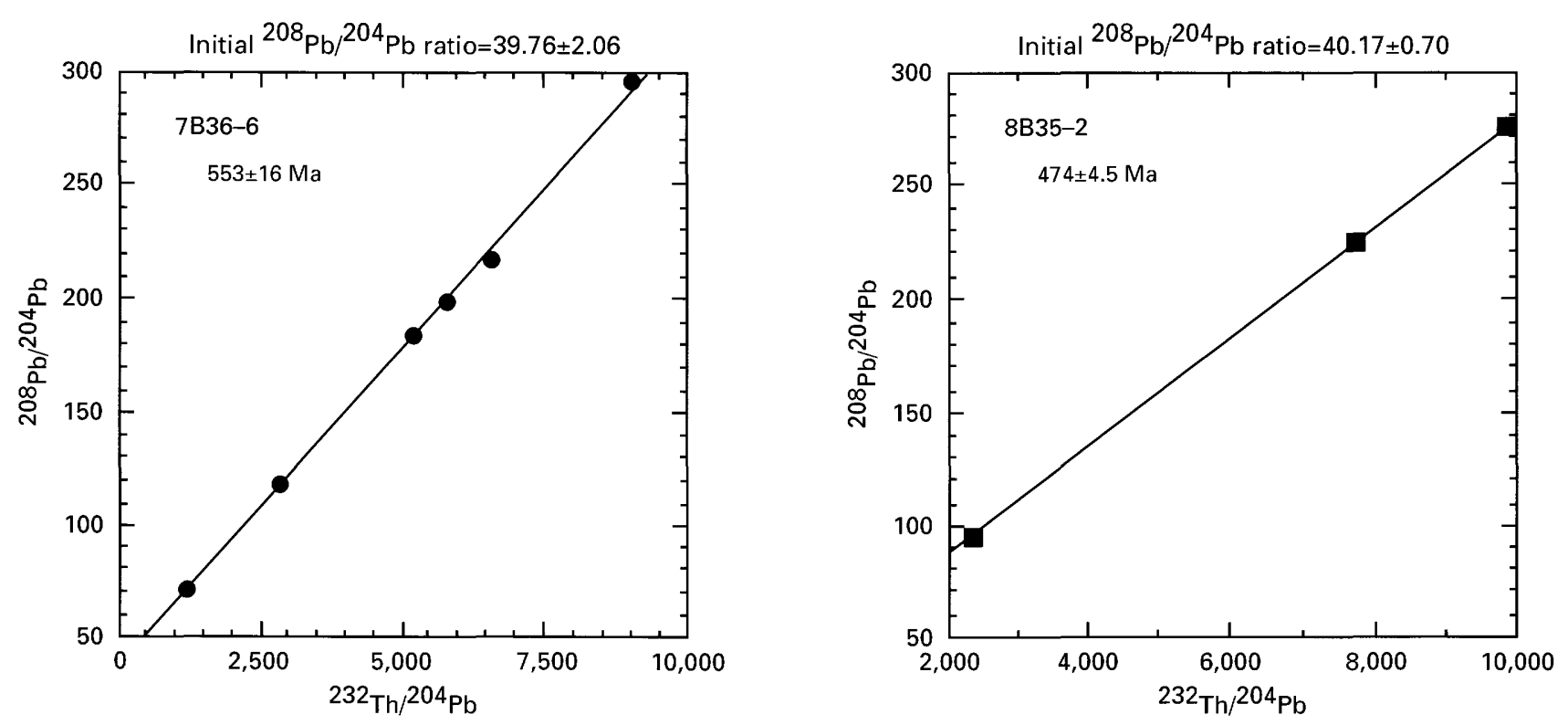

Figure 20. Internal isochrons of monazite from two samples (7B36-6 and 8B35-2) of Bayan Obo ores that show nearly identical ${ }^{208} \mathrm{~Pb} /{ }^{204} \mathrm{~Pb}$ initial ratios indicate different internal isochron ages, suggesting a common source reservoir that was tapped at different times. 

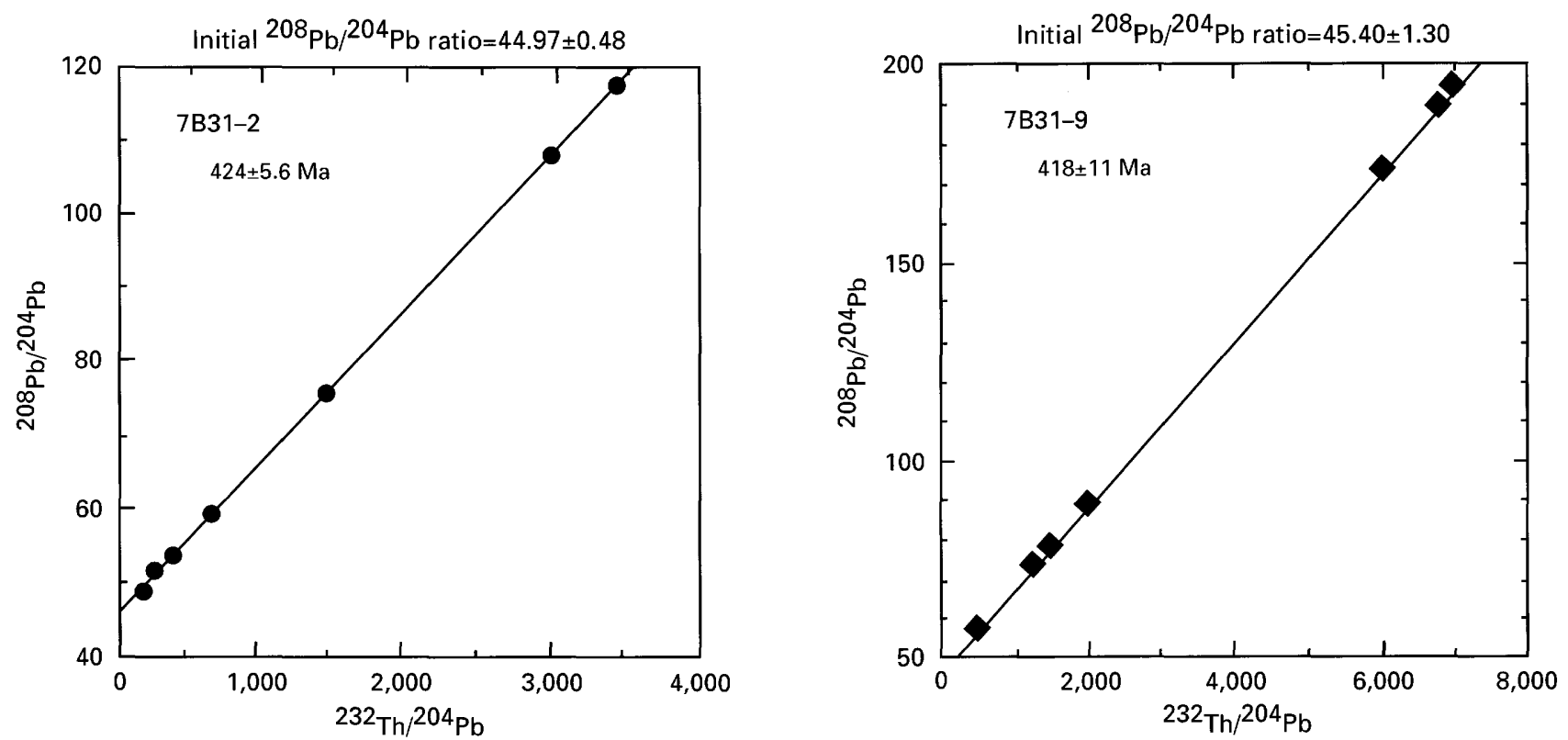

Figure 21. Internal isochrons of monazite from two samples (7B31-2 and 7B31-9) of Bayan Obo ores that have essentially the same internal isochron mineral ages and ${ }^{208} \mathrm{~Pb} / 204 \mathrm{~Pb}$ initial ratios. The monazites in these samples probably were deposited from the same hydrothermal solutions.
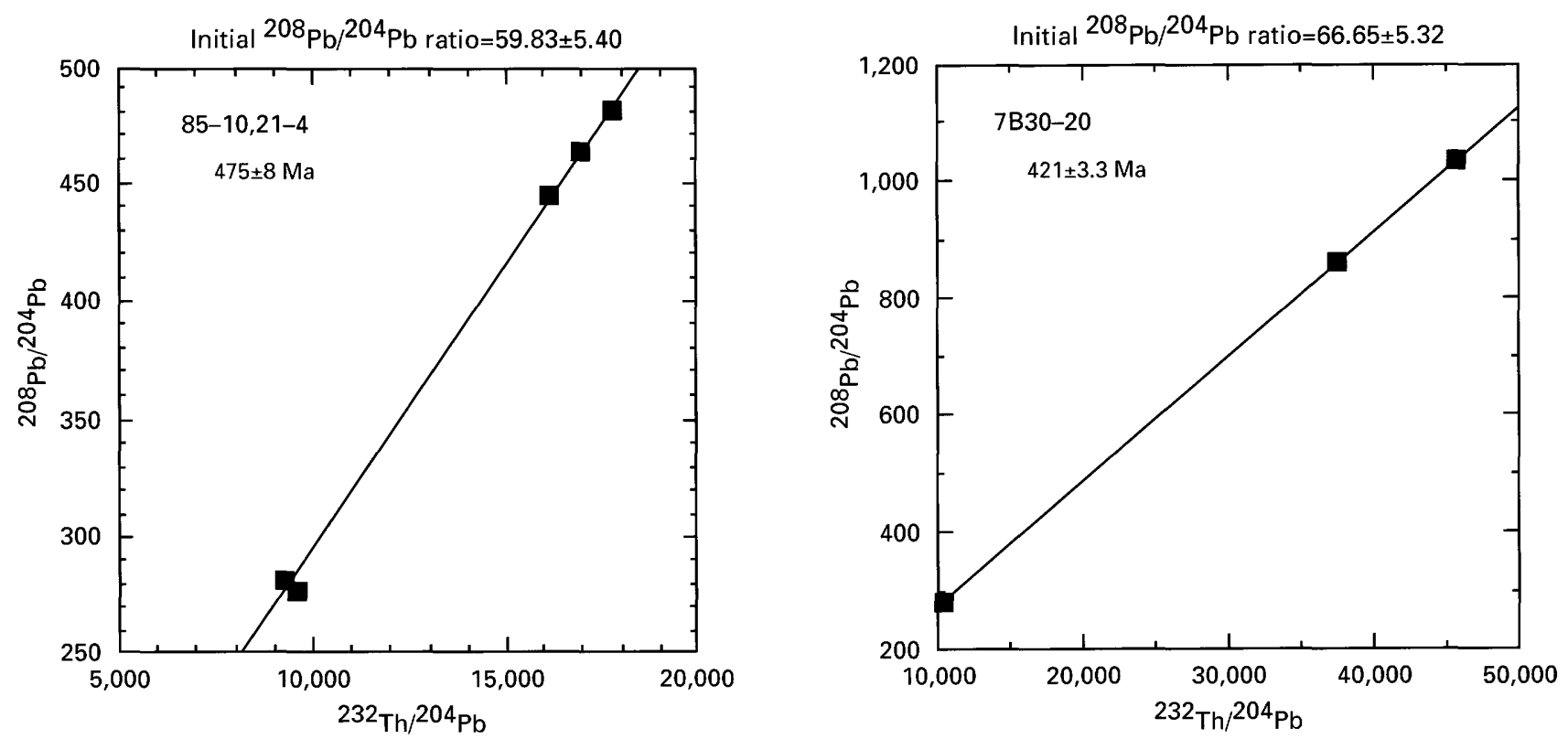

Figure 22. Internal isochrons of bastnaesite from sample 85-10,21-4 and monazite from sample 7B30-20 having different internal isochron mineral ages but high radiogenic ${ }^{208} \mathrm{~Pb} /{ }^{204} \mathrm{~Pb}$ initial ratios. 
has an internal mineral isochron age of $553 \pm 16 \mathrm{Ma}$ and a ${ }^{208} \mathrm{~Pb} /{ }^{204} \mathrm{~Pb}$ initial ratio of $39.76 \pm 2.06$ that is indistinguishable from the ${ }^{208} \mathrm{~Pb} /{ }^{204} \mathrm{~Pb}$ initial ratio of monazite sample 8B35-2 (fig. 20), 40.17 \pm 0.70 . The internal isochron age of monazite sample $8 \mathrm{~B} 35-2$ is $474 \pm 4.5 \mathrm{Ma}$, clearly younger than $553 \pm 16 \mathrm{Ma}$, and may indicate that the same or similar source reservoir for REE's was tapped and mobilized at different times. Monazites from samples 7B31-2 and 7B31-9 are similar in REE chemical composition (table 14) and indistinguishable in internal isochron age and ${ }^{208} \mathrm{~Pb} / 204 \mathrm{~Pb}$ initial ratios (fig. 21). Therefore, it is probable that the monazites from 7B31-2 and 7B31-9 originated concurrently from hydrothermal solutions derived from the same source reservoir. These two samples were collected more than 50 $\mathrm{m}$ apart, about $130 \mathrm{~m}$ above the footwall of the East Orebody (fig. 5).

Bastnaesite from sample 85-10,21-4 (table 14 and fig. 22) has an internal isochron mineral age of $475 \pm 8 \mathrm{Ma}$ and a very high ${ }^{208} \mathrm{~Pb} / 204 \mathrm{~Pb}$ initial ratio of $59.83 \pm 5.40$. Monazite from sample 7B30-20 (table 14 and fig. 22), with an age of $421 \pm 3.3 \mathrm{Ma}$, has one of the lowest $\mathrm{La}_{2} \mathrm{O}_{3}$ contents and the highest $\mathrm{Nd}_{2} \mathrm{O}_{3}$ content, as well as one of the highest, most radiogenic ${ }^{208} \mathrm{~Pb} / 204 \mathrm{~Pb}$ initial ratios $(66.65 \pm 5.32)$. These two REE samples came from different hydrothermal solutions, not only different from each other but also from the solutions giving rise to the rest of the analyzed REE samples.

Spatial relations of REE mineralized samples are generally lacking. Four of the dated samples are however from the same drill core. They are 796-48,270, 796-48,277, $796-48,278$, and 796-48,280 (table 14). Except 796-48,280 (depth $280 \mathrm{~m}$ ), where bastnaesite is the REE mineral dated with an internal isochron age of $496 \pm 13 \mathrm{Ma}$, the other three are monazite samples, from depths of 270,277 , and $278 \mathrm{~m}$, respectively. Monazite from $796-48,270,415 \pm 17 \mathrm{Ma}$, is from a banded ore hosted by dolomite marble and associated with granular aegirine, magnetite, phlogopite, and fluorite; monazite from sample $796-48,277,432 \pm 8.5 \mathrm{Ma}$, is from a disseminated ore hosted by limestone marble and associated with abundant alkali amphibole, magnetite, and small amounts of aegirine, fluorite, and pyrite; and monazite from $796-48,278,419 \pm 3.7 \mathrm{Ma}$, is also from a disseminated ore hosted by limestone marble and associated with alkali amphibole, magnetite, fluorite, and pyrite. None of these three monazites can be distinguished readily by age, chemical composition, or initial ${ }^{208} \mathrm{~Pb} /{ }^{204} \mathrm{~Pb}$ ratio (owing to large uncertainties). These three samples may be considered to be of similar age and deposited by the same hydrothermal source.

The internal isochron mineral ages of episodes of monazite and bastnaesite mineralization are shown in table 14 and figures 18-22, 32, and 33. The episodes of REE mineralization recorded so far ranged from 555 to $398 \mathrm{Ma}$, covering a geologic time span of more than 150 million years. Chao and others $(1992,1993)$, on the basis of preliminary partial internal isochron and chemical data, concluded that the role of REE remobilization from carbonate host rocks was improbable, and that the effects of low-grade Caledonian and Hercynian regional metamorphism and Hercynian granitic intrusion on the ages of REE mineralization were minimal. The extensive and refined detailed data presented by Wang and others (1994) and in this paper, particularly the more complete chemical, isotopic, and initial ${ }^{208} \mathrm{~Pb} /{ }^{204} \mathrm{~Pb}$ ratios, fully substantiate the earlier conclusions. Most monazites with different internal isochron ages, chemical compositions, and initial ${ }^{208} \mathrm{~Pb} /{ }^{204} \mathrm{~Pb}$ ratios were probably brought in at different times and deposited by different hydrothermal solutions.

\section{Fe MINERALIZATION}

In general, there are three major Fe-oxide minerals associated with $\mathrm{Fe}$ mineralization, each perhaps occurring in more than one generation. These are (1) euhedral martite or martitized magnetite grains scattered in disseminated ores, in scattered aggregates in bands of banded ores, and in massive ores; (2) fine-grained to very fine grained primary granular hematite that forms disseminated patches and scattered lenses in dolostone marble disseminated ores and in bands in banded ores, and also occurs in massive ores; and (3) nonmartitized magnetite in disseminated, banded, and massive ores. Massive Fe ores commonly consist of a combination of the above three Fe-oxide minerals. Additional, but minor, occurrences of Fe minerals are very fine grained disseminated magnetite with rims of hematite, rare wormy textures in hematitic ores, and goethite in weathered $\mathrm{Fe}$ oxide ores. The rimmed and wormy textures may be of metamorphic origin.

Data on ages of $\mathrm{Fe}$ mineralization are fragmentary because the Fe-oxide minerals cannot be isotopically dated and we were not successful in identifying various generations of fresh magnetite in terms of trace-element contents. Hence, textural relations among Fe-oxide minerals and dated REE minerals and alkali amphiboles were used to help determine the relative paragenetic sequence for $\mathrm{Fe}$ mineralization. These data yielded age information regarding only the latest and not the earliest age of Fe mineralization, but indicated that euhedral martite and martitized magnetite formed before granular hematite in disseminated and banded ores, and fresh magnetite formed last in disseminated, banded, and massive ores.

Euhedral martite and martitized magnetite are apparently the oldest $\mathrm{Fe}$ ore minerals in ores hosted by dolostone marble. Martite and martitized magnetite crystals are euhedral crystals of magnetite completely or partially replaced pseudomorphously along crystallographic directions of the original magnetite host. Thus, they record a two-phase process: the deposition of euhedral magnetite and later pseudomorphous replacement of magnetite by hematite. Where martite or martitized magnetite occurs with granular hema- 


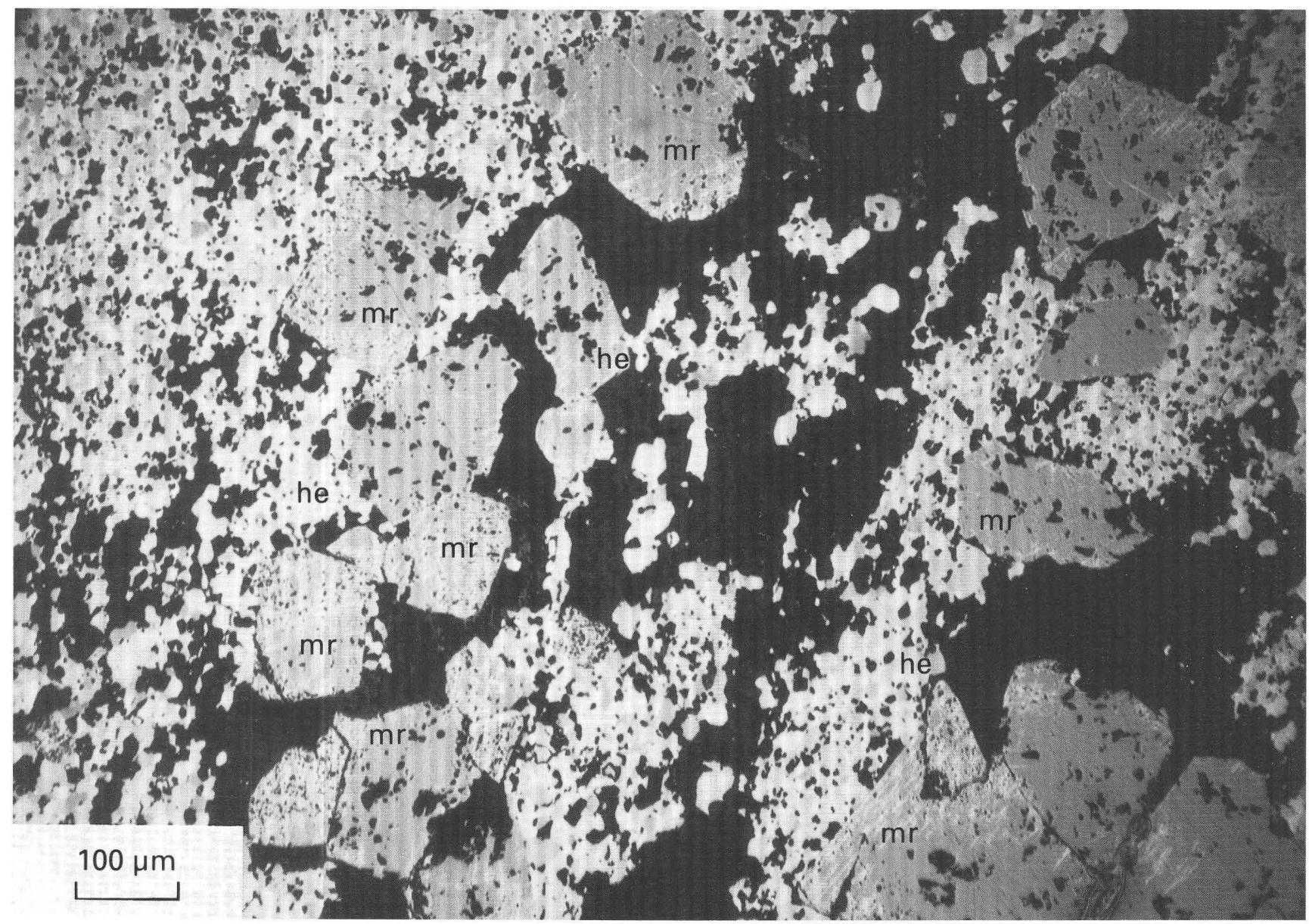

Figure 23. Photomicrograph of a doubly polished thin section of sample 8B2-2 showing euhedral martitized magnetite (mr) crystals blocking the continuous formation of later fine-grained hematite (he). Some martite crystals are completely surrounded by the granular hematite. (Reflected light, crossed nicols.)

tite, such as in some of the banded REE-Fe ores, texturally, martite and martitized magnetite preceded the granular hematite. This relation is illustrated where preexisting martitized magnetic crystals blocked the formation of continuous bands of granular hematite (fig. 23) and where euhedral martite crystals are completely embedded in fine, granular hematite (fig. 24). We interpret these relations to indicate that euhedral magnetite crystals formed first and were pseudomorphously replaced by hematite along crystallographic directions. The martite locally blocked and was incorporated into the younger bands of granular hematite.

Granular hematite represents the next type of Fe mineralization. Evidence for the earliest episodes of granular hematite mineralization is found in sample 8B35-2, where fine-grained hematite with associated $\mathrm{Nb}$-rutile replaced monazite with an age of $474 \pm 4.5 \mathrm{Ma}$ (table 14), and therefore crystallized after that date. Unfortunately, a minimum age for the hematite cannot be determined. Similarly, granular hematite progressively replaced dated monazite in sample 7B30-20 (figs. 25 and 26) and is, therefore, younger than $421 \pm 3.3 \mathrm{Ma}$, the radiometrically determined age of the monazite. The monazite of sample 7B30-20 has about equal concentrations of $\mathrm{La}_{2} \mathrm{O}_{3}$ (13.60 wt. percent) and $\mathrm{Nd}_{2} \mathrm{O}_{3}$ (13.61 wt. percent) (table 14), which are low for $\mathrm{La}_{2} \mathrm{O}_{3}$ and uniquely high for $\mathrm{Nd}_{2} \mathrm{O}_{3}$ at Bayan Obo. Because of the unique chemical composition of this dated monazite, it can be used as a guidepost for estimating relative ages of minerals formed, based on textural evidence, before and after this 


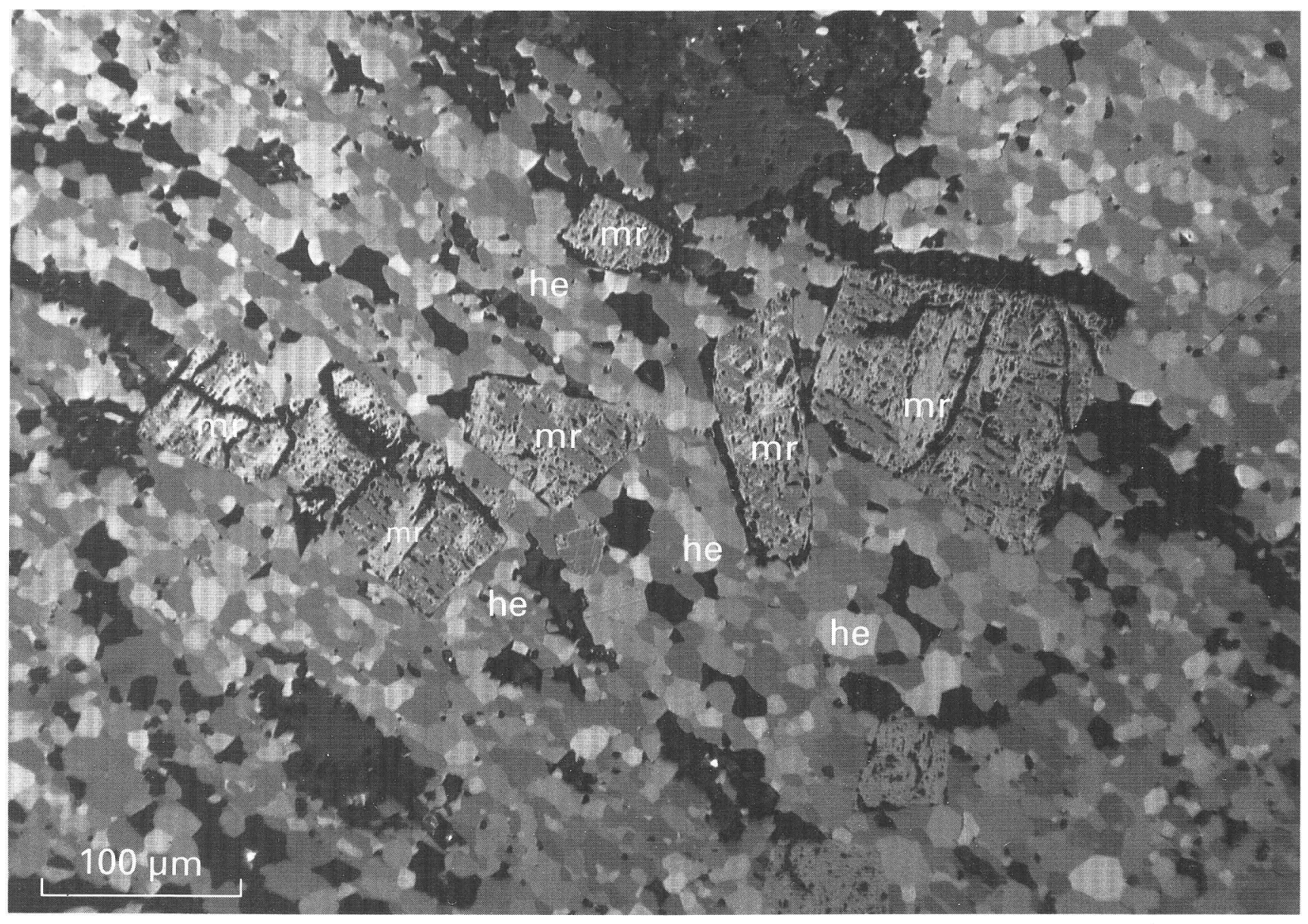

Figure 24. Photomicrograph of a doubly polished thin section of sample 7B37-1 showing euhedral martite (mr) crystals embedded in fine granular hematite (he). (Reflected light, crossed nicols.) 


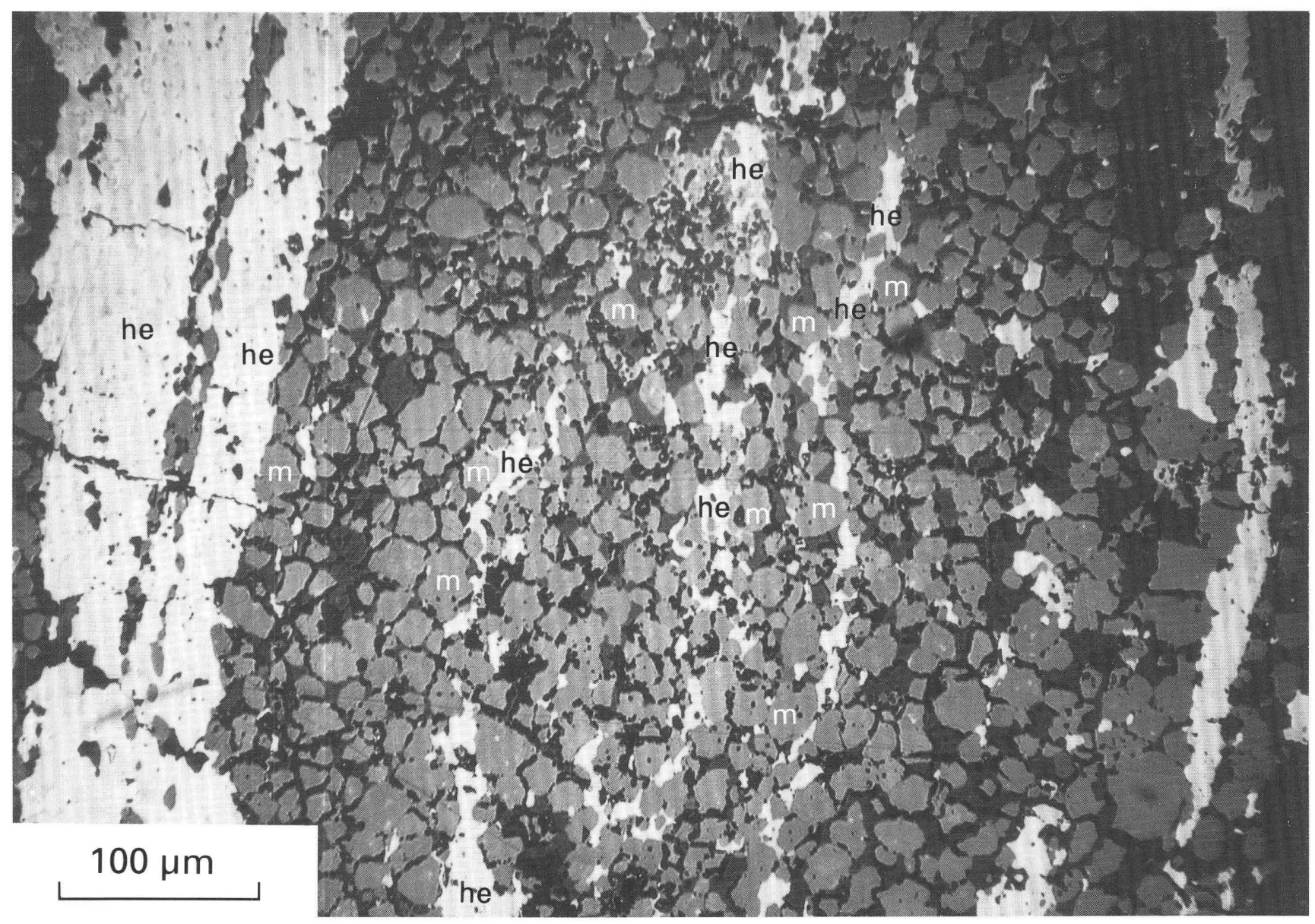

Figure 25. Photomicrograph of a doubly polished thin section of sample 7B30-20 showing bands of granular monazite (m) replaced interstitially by fine granular hematite (he). (Reflected light, crossed nicols.) 


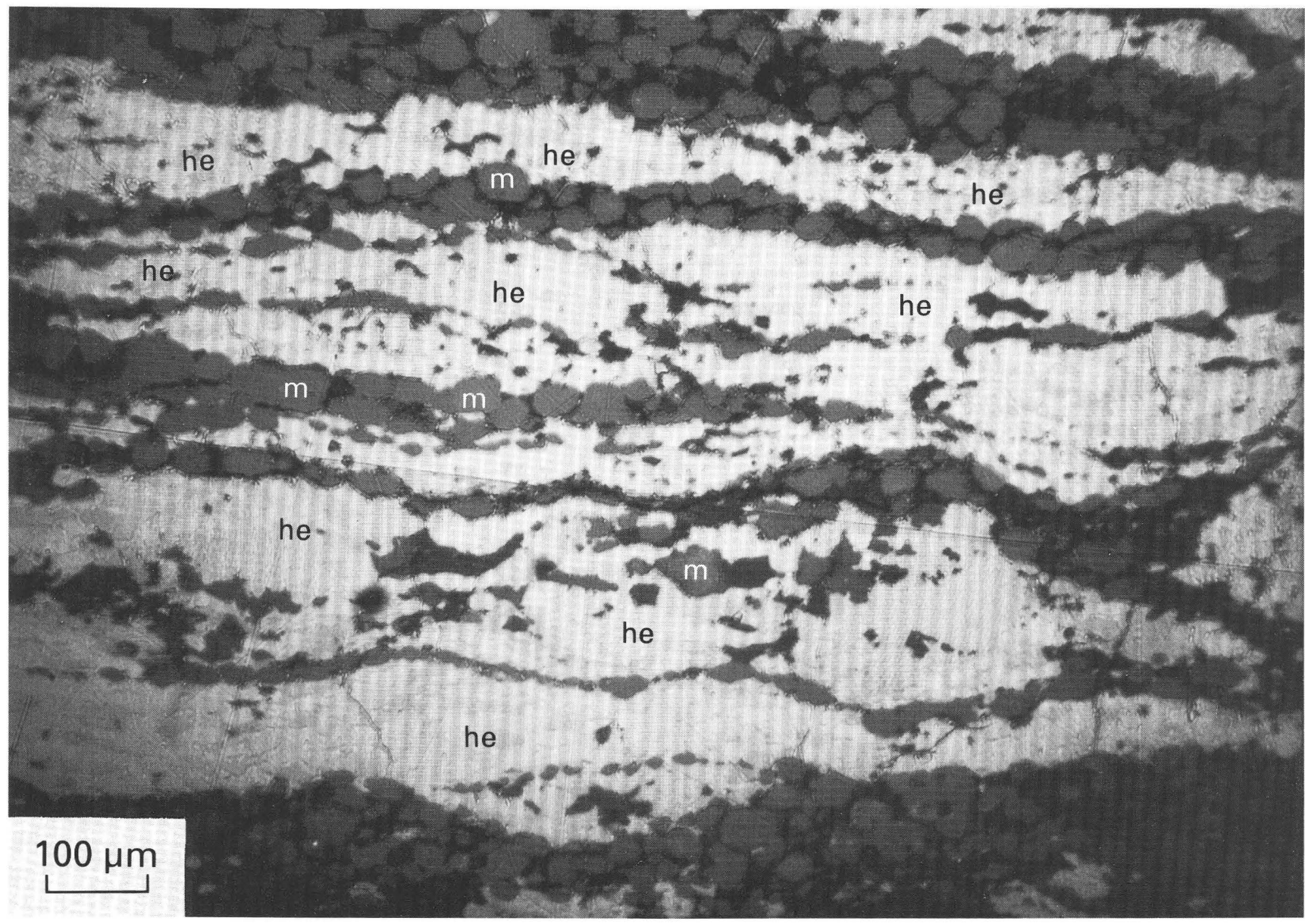

Figure 26. Photomicrograph of a doubly polished thin section of sample 7B30-20 showing strings of rounded monazite (m) surrounded and replaced interstitially by fine granular hematite (he). (Reflected light, crossed nicols.)

monazite crystallized. Hematite bands in ores were cut by alkali amphibole veins (sample 7B30-30) with an ${ }^{40} \mathrm{Ar} /{ }^{39} \mathrm{Ar}$ plateau age of 395.8 $\pm 6.2 \mathrm{Ma}$; hence, the age of mineralization of some of the primary granular hematite probably lies between 421 and $396 \mathrm{Ma}$.

The occurrence of fresh magnetite in folded banded ore and in undeformed massive $\mathrm{Fe}$ ores indicates that at least two generations of fresh magnetite ores are present at Bayan Obo and apparently postdate the granular hematite. The textural relation between early granular hematite and late magnetite can be seen in sample 7B31-6, where a veinlet of fresh magnetite crosscuts bands of monazite and fine, granular hematite in banded REE-Fe ore (fig. 27); in sample 9B15-1L, where banded granular hematite-monazite-fluorite ore was replaced and cut by fresh massive magnetite (fig. 28); and in sample 796-48,517, where relict bands of granular hematite and monazite were disrupted and sur- rounded by fresh magnetite (figs. $29 A$ and $B$ ). These relations also indicate that massive magnetite ores formed after banded ores and are supported by the apparent textural zoning in the Main and East Orebodies, where massive Fe ores occur in the center of the orebodies and are surrounded by banded ores.

The ${ }^{40} \mathrm{Ar} /{ }^{39} \mathrm{Ar}$ ages of coexisting alkali amphiboles can further refine the ages of $\mathrm{Fe}$ mineralization and also add information about the long period of time the mine area was subjected to hydrothermal activity. For example, in sample 796-48,277, a drill hole sample of low-grade, disseminated monazite-magnetite ore that contains abundant alkali amphibole (figs. $30 A$ and $B$ ), host limestone marble was replaced by aggregates of fine-grained monazite, which were in turn enclosed and replaced by alkali amphibole. Fresh magnetite replaced both monazite and alkali amphibole and is, therefore, younger than these phases. In this 


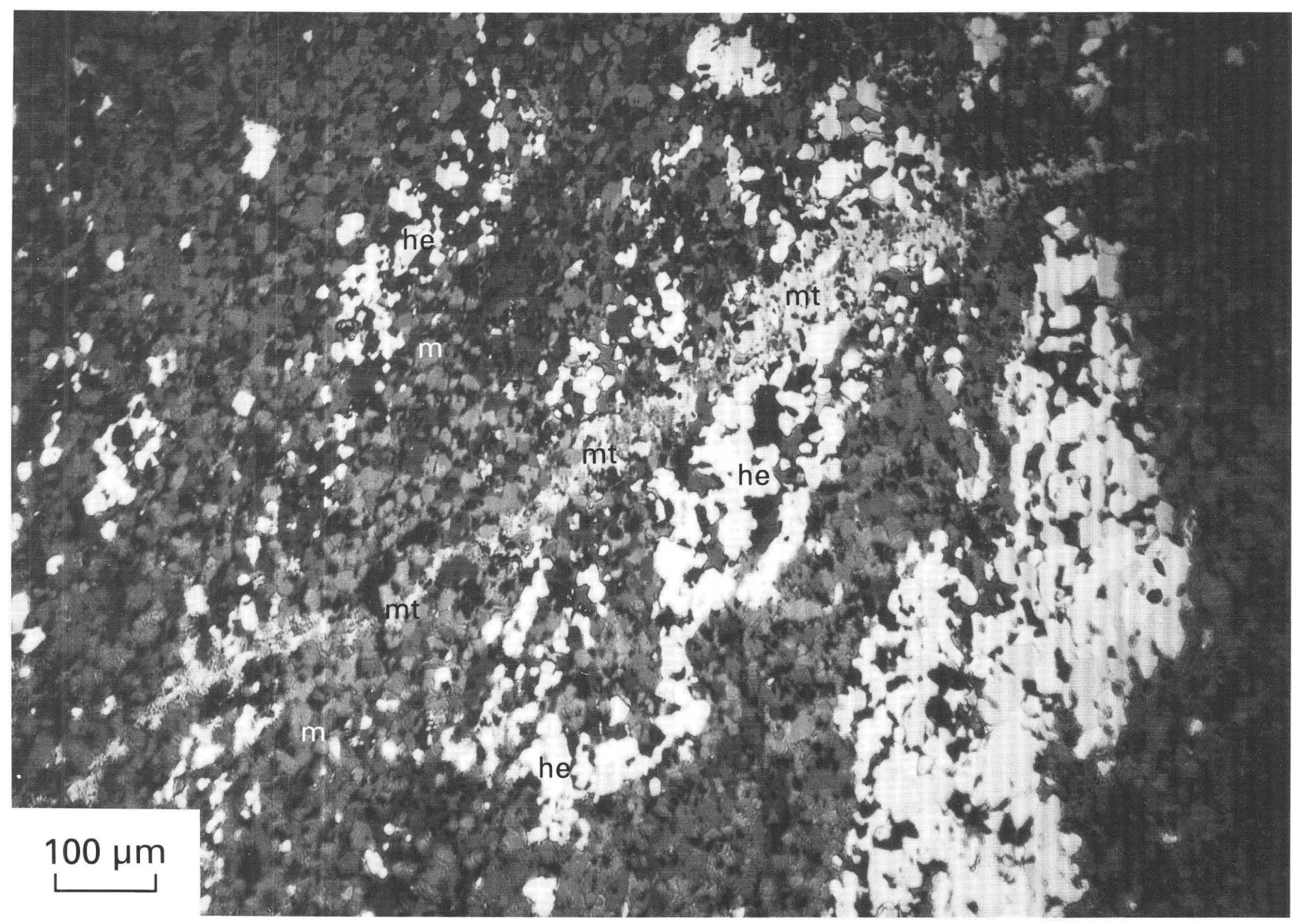

Figure 27. Photomicrograph of a doubly polished thin section of sample 7B31-6 showing a magnetite (mt) veinlet cutting a banded monazite (m)-bearing granular hematite (he) ore. (Reflected light, crossed nicols.)

sample, the monazite was determined to be $432 \pm 8.5 \mathrm{Ma}$ (table 14 and fig. $31 A$ ) by the ${ }^{232} \mathrm{Th} /{ }^{208} \mathrm{~Pb}$ internal isochron method, and the alkali amphibole (magnesio-arfvedsonite) has a plateau age of $343.1 \pm 3.0 \mathrm{Ma}$ (table 15 and fig. $31 B$ ), which is considered to be a minimum age, determined by the ${ }^{40} \mathrm{Ar} /{ }^{\beta 9} \mathrm{Ar}$ incremental heating method. The age and relatively flat spectrum for this metasomatic-metamorphic amphibole suggest that it has not been significantly reset by the younger Hercynian granitic intrusion or regional metamorphism. Because the magnetite replaces the alkali amphibole, the age of this magnetite is younger than the age of the alkali amphibole, about $343 \mathrm{Ma}$. Although the age difference between monazite and amphibole, about 90 m.y., is large, the ages are well documented and are consistent with the textural relations. In samples 8B7 and 34-24, alkali amphibole also replaced REE minerals, and the ages of the amphibole and REE phases have been determined. Bast- naesite in sample $8 \mathrm{~B} 7$ is $555 \pm 11 \mathrm{Ma}$ (fig. $32 \mathrm{~A}$ ), and alkali amphibole in the same sample is $395.5 \pm 4.4 \mathrm{Ma}$ (table 15 and fig. $32 B$ ). In sample $34-24$, the monazite is $532 \pm 3.1 \mathrm{Ma}$ (table 14), and the coexisting alkali amphibole, dated by the $\mathrm{K}-\mathrm{Ar}$ method by the Tianjin laboratory, is $441 \pm 11 \mathrm{Ma}$. In samples $796-48,277$ and $8 \mathrm{~B} 7$, there is a possibility that the alkali amphibole may have been reset by the replacement and mineralization of late-stage fresh magnetite. If so, then the determined minimum alkali amphibole ages date the age of magnetite mineralization. In sample 34-24, magnetite is not present; hence, resetting of the alkali amphibole age by late-stage magnetite-precipitating hydrothermal solutions is unlikely.

Text continues on p. 50 . 


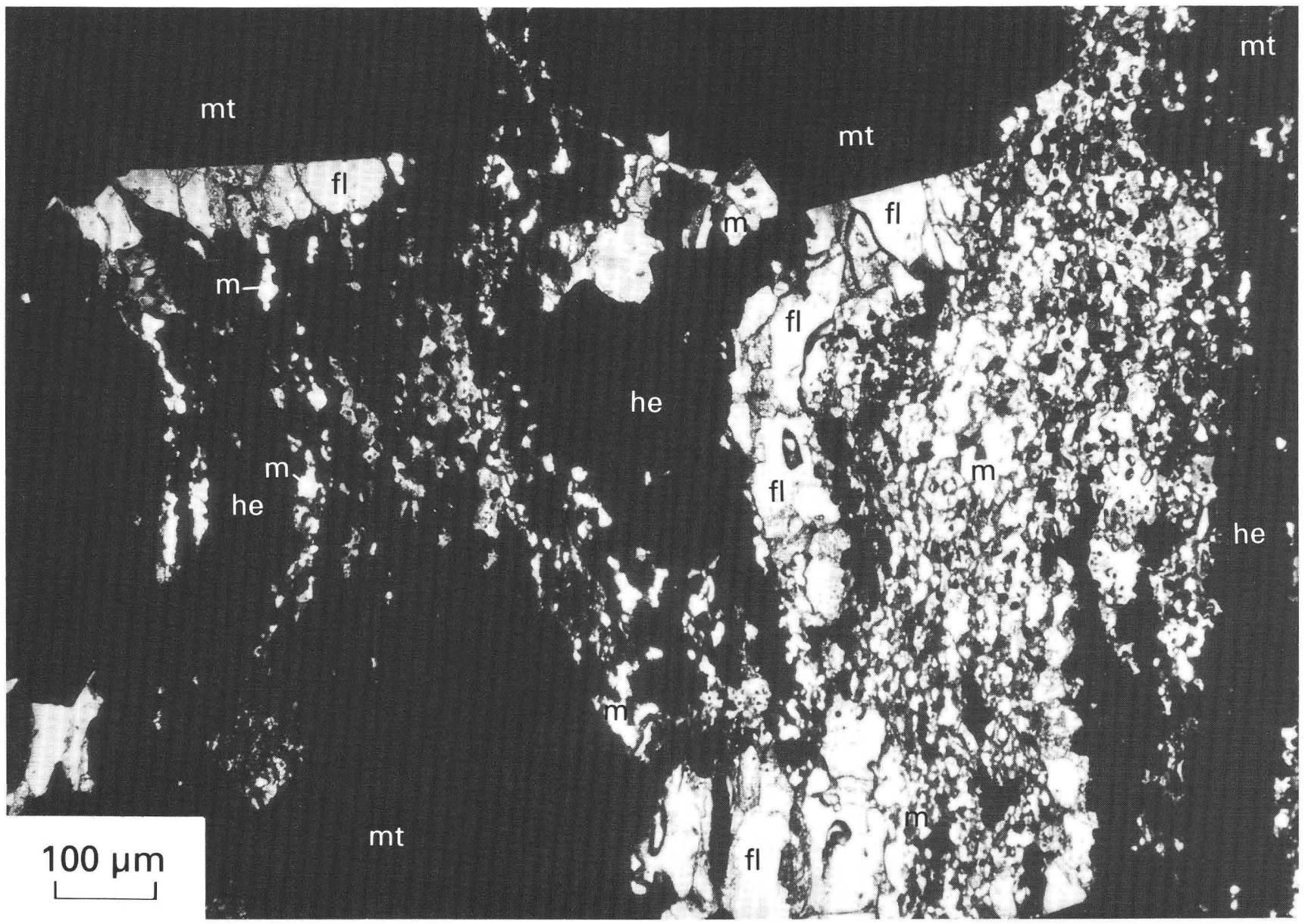

Figure 28. Photomicrograph of a doubly polished thin section of sample 9B15-1L showing a banded ore consisting of monazite (m)granular hematite (he)-fluorite (fl) cut by late-stage, coarse-grained fresh magnetite (mt) aggregates. (Transmitted light, crossed nicols.) 
Table 15. Chemical composition (wt. percent) and minimum mineral ages of various generations of selected alkali amphiboles of Bayan Obo.

[Analysts: J.M. Back and J.A. Minkin. Analysis by electron microprobe (EPMA). ${ }^{*}$, below minimum detection level (MDL); $\mathrm{MDL}$ for $\mathrm{TiO}_{2}=0.04 . \mathrm{Minimum}{ }^{40} \mathrm{Ar} /{ }^{39} \mathrm{Ar}$ mineral ages determined by J.E. Conrad, E.H. McKee, and B.D. Turrin; n.d., not determined]

\begin{tabular}{|c|c|c|c|c|c|c|c|c|c|c|c|c|c|}
\hline Sample no....... & Drew 1 & $7 \mathrm{~B} 13 \mathrm{C}$ & $40-14$ & $8 B 24-1$ & $7 \mathrm{~B} 25-2$ & $8 \mathrm{~B} 42$ & 7B34-1P & $7 B 34-1 F$ & $796-48,252$ & $796-48,366$ & $7 B 30-30$ & $8 B 7$ & $796-48,277$ \\
\hline $\mathrm{SiO}_{2}$ & 55.07 & 56.01 & 56.55 & 55.31 & 57.19 & 55.96 & 57.54 & 57.24 & 55.98 & 53.53 & 55.90 & 55.75 & 53.85 \\
\hline $\mathrm{TiO}_{2}$ & .07 & .25 & .04 & & .12 & $*$ & $*$ & .05 & .06 & $*$ & $*$ & $*$ & .04 \\
\hline $\mathrm{Al}_{2} \mathrm{O}_{3}$ & .55 & .26 & .59 & .33 & .46 & .48 & .37 & .26 & .66 & .70 & .58 & .47 & .44 \\
\hline $\mathrm{MnO}$ & .30 & .62 & .13 & .13 & .04 & 2.82 & .08 & .13 & .91 & 4.91 & .57 & .90 & 5.68 \\
\hline $\mathrm{MgO}$ & 10.28 & 14.95 & 15.96 & 17.96 & 18.55 & 12.88 & 17.12 & 18.34 & 14.01 & 11.84 & 15.44 & 19.30 & 12.47 \\
\hline $\mathrm{CaO}$ & .48 & .65 & .61 & 2.01 & 1.06 & 1.77 & .72 & 4.15 & 2.33 & 2.56 & 2.69 & 3.28 & 1.92 \\
\hline $\mathrm{Na}_{2} \mathrm{O}$ & 7.33 & 7.69 & 7.03 & 7.74 & 7.18 & 7.19 & 8.98 & 6.13 & 6.74 & 6.74 & 7.17 & 6.91 & 7.64 \\
\hline $\mathrm{K}_{2} \mathrm{O}$ & 1.03 & 1.95 & 2.93 & 2.00 & 2.26 & 2.21 & 1.18 & 1.18 & 1.02 & 2.14 & 1.57 & .67 & 1.90 \\
\hline $\mathrm{F}$ & .98 & 2.03 & 2.51 & 2.20 & 2.52 & 2.87 & 2.56 & 1.38 & 2.04 & 3.08 & 2.81 & 3.40 & 3.41 \\
\hline Total & 98.83 & 98.56 & 99.59 & 96.52 & 98.67 & 101.66 & 101.35 & 99.67 & 100.93 & 99.80 & 101.18 & 100.23 & 99.94 \\
\hline$-\mathrm{O}=\mathrm{F}$ & 0.41 & 0.85 & 1.06 & 0.93 & 1.06 & 1.21 & 1.08 & 0.58 & 0.86 & 1.30 & 1.18 & 1.43 & 1.44 \\
\hline Total & 98.42 & 97.71 & 98.53 & 95.59 & 97.61 & 100.45 & 100.27 & 99.09 & 100.07 & 98.50 & 100.00 & 98.80 & 98.50 \\
\hline \multicolumn{14}{|l|}{$\begin{array}{l}\text { Minimum } \\
\text { mineral }\end{array}$} \\
\hline age (Ma) & 1,260 & 820 & 890 & 890 & n.d. & n.d. & $424.8 \pm 2.4$ & $428.0 \pm 7.3$ & $419.5 \pm 2.0$ & n.d. & $395.8 \pm 6.2$ & $395.5 \pm 4.4$ & $343.1 \pm 3.0$ \\
\hline
\end{tabular}

${ }^{1}$ Total $\mathrm{Fe}$ as FeO. 


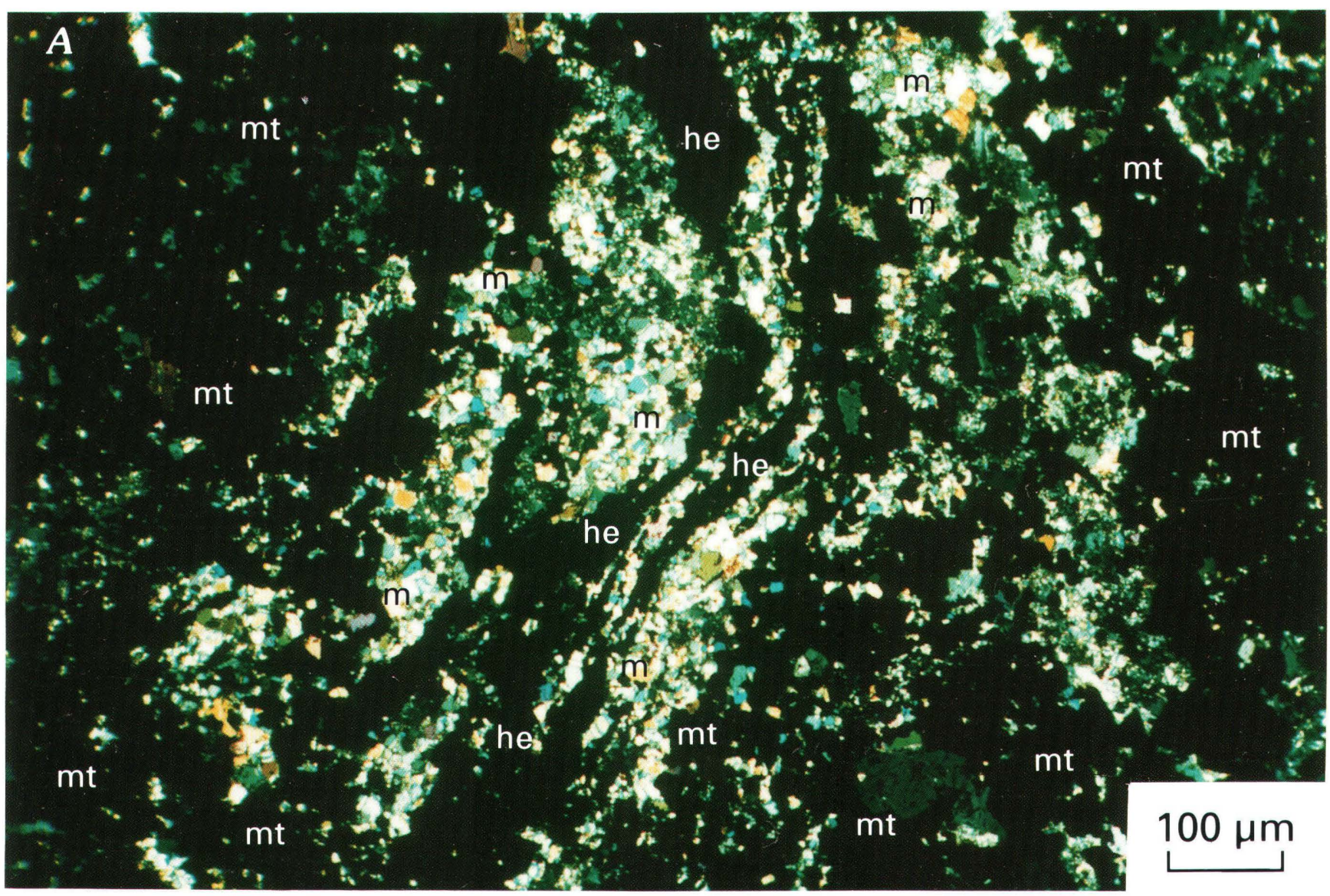

Figure 29. Photomicrographs of a doubly polished thin section of sample 796-48,517 showing relict banded ore consisting of folded monazite (m) and granular hematite (he) surrounded and replaced by late-stage, fresh magnetite (mt). $A$, Transmitted light; $B$, Reflected light. 


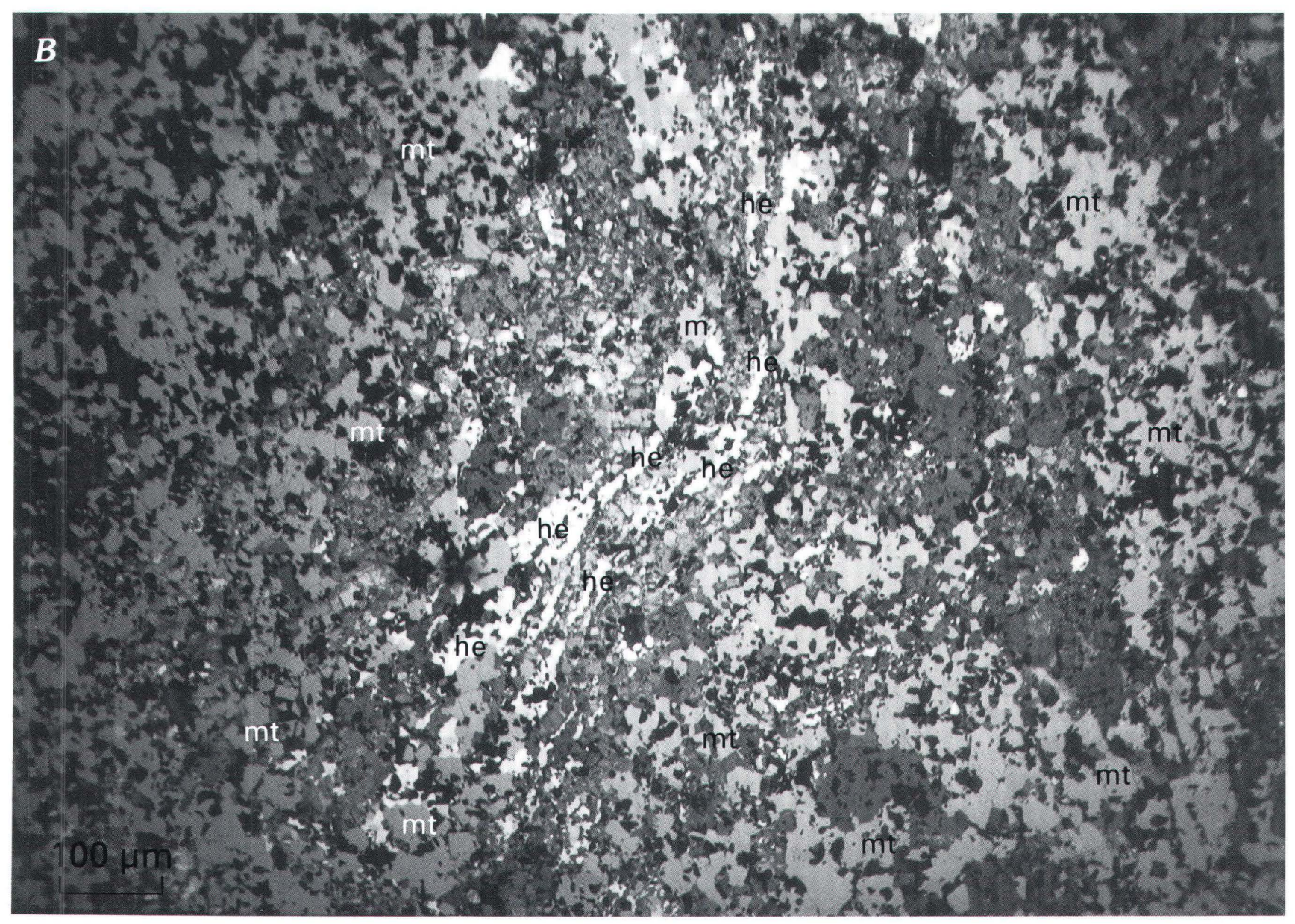

Figure 29. Continued. 


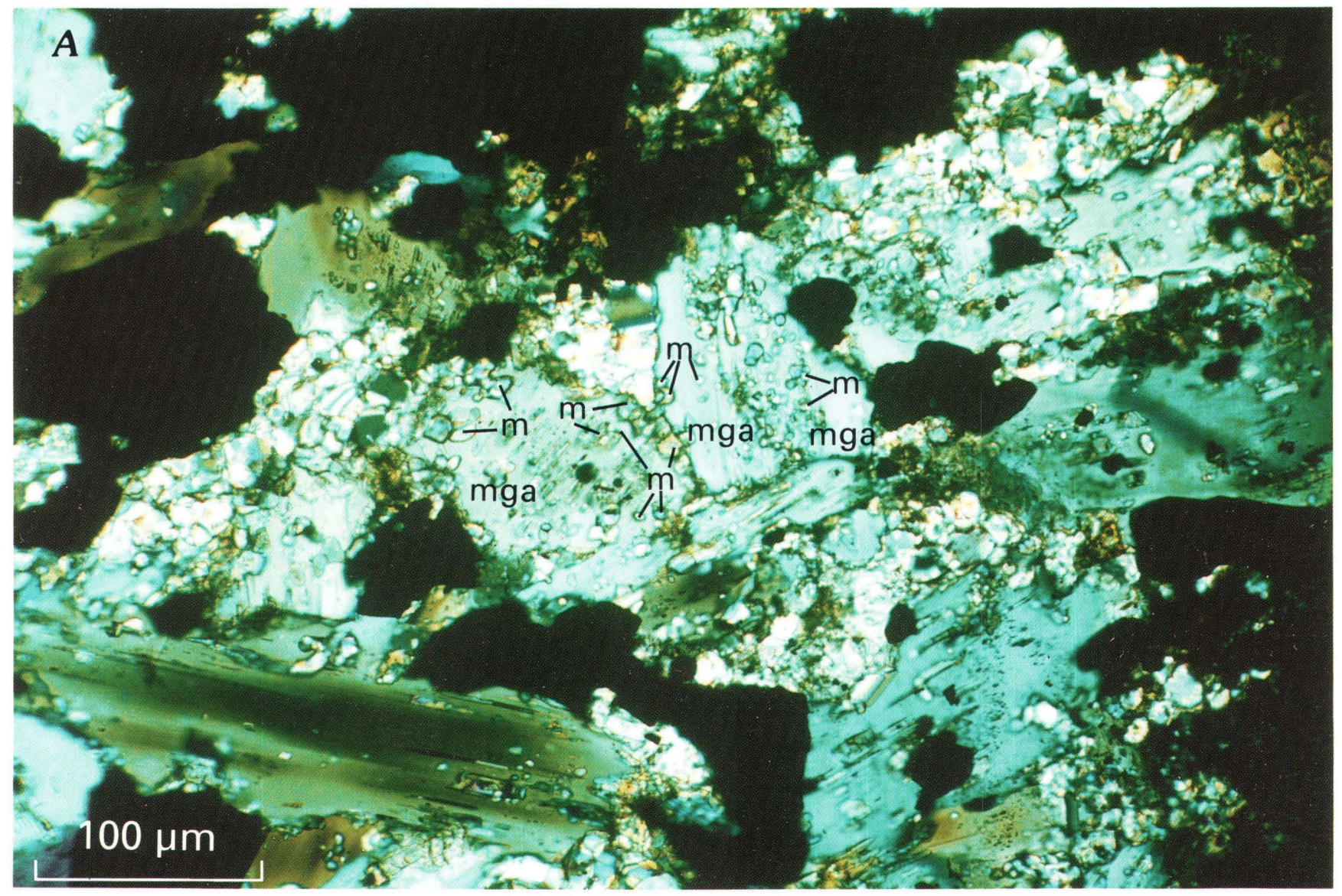

Figure 30. Photomicrographs of a doubly polished thin section of sample 796-48,277, a low-grade ore consisting of alkali amphibole (mga), monazite (m), and magnetite (mt), as well as relict grains of the limestone marble host rock. The alkali amphiboles contain inclusions of monazite. Monazite and alkali amphiboles are replaced and cut by fresh magnetite. $A$, Transmitted light; $B$, Reflected light. 


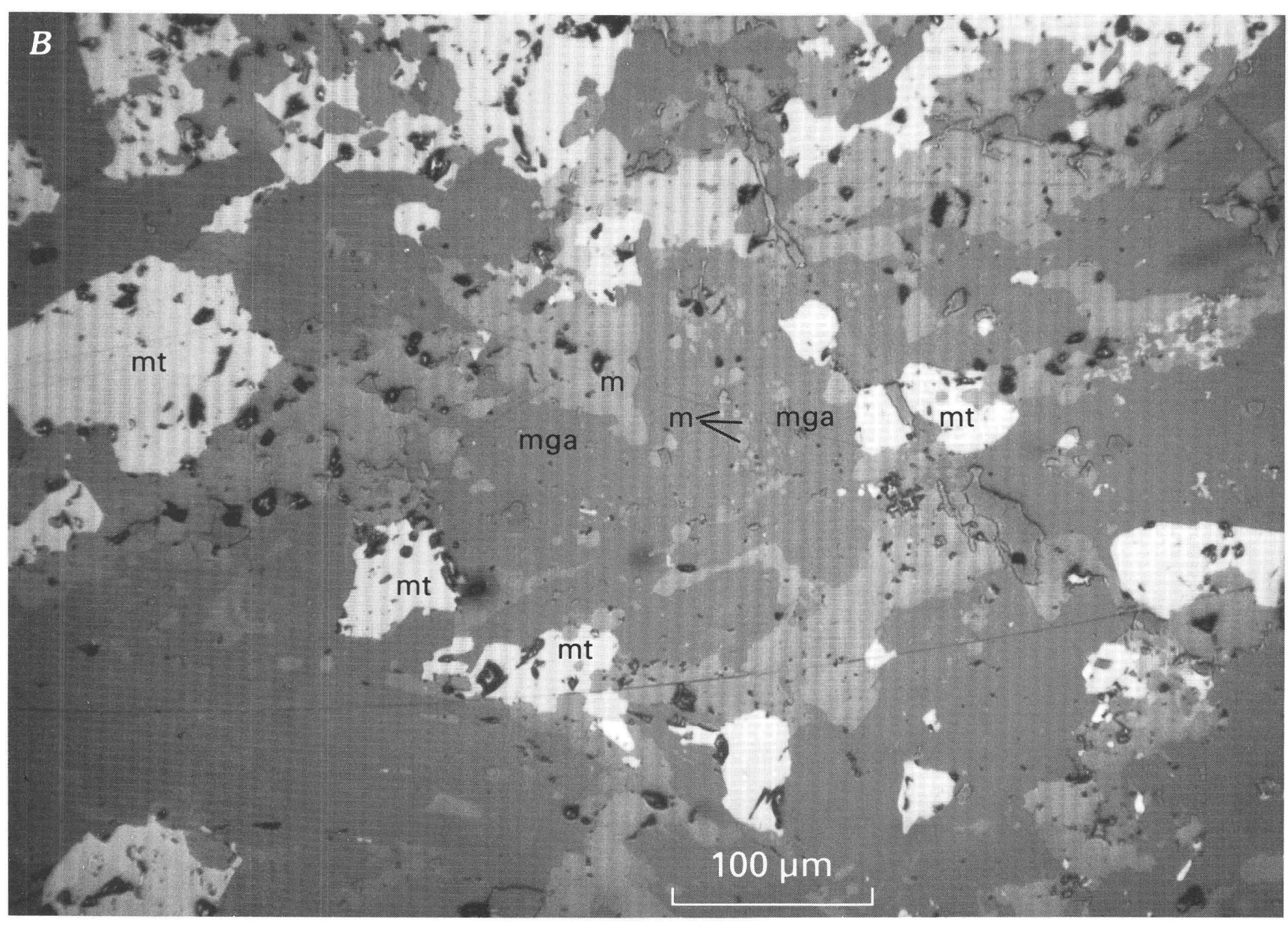

Figure 30. Continued. 

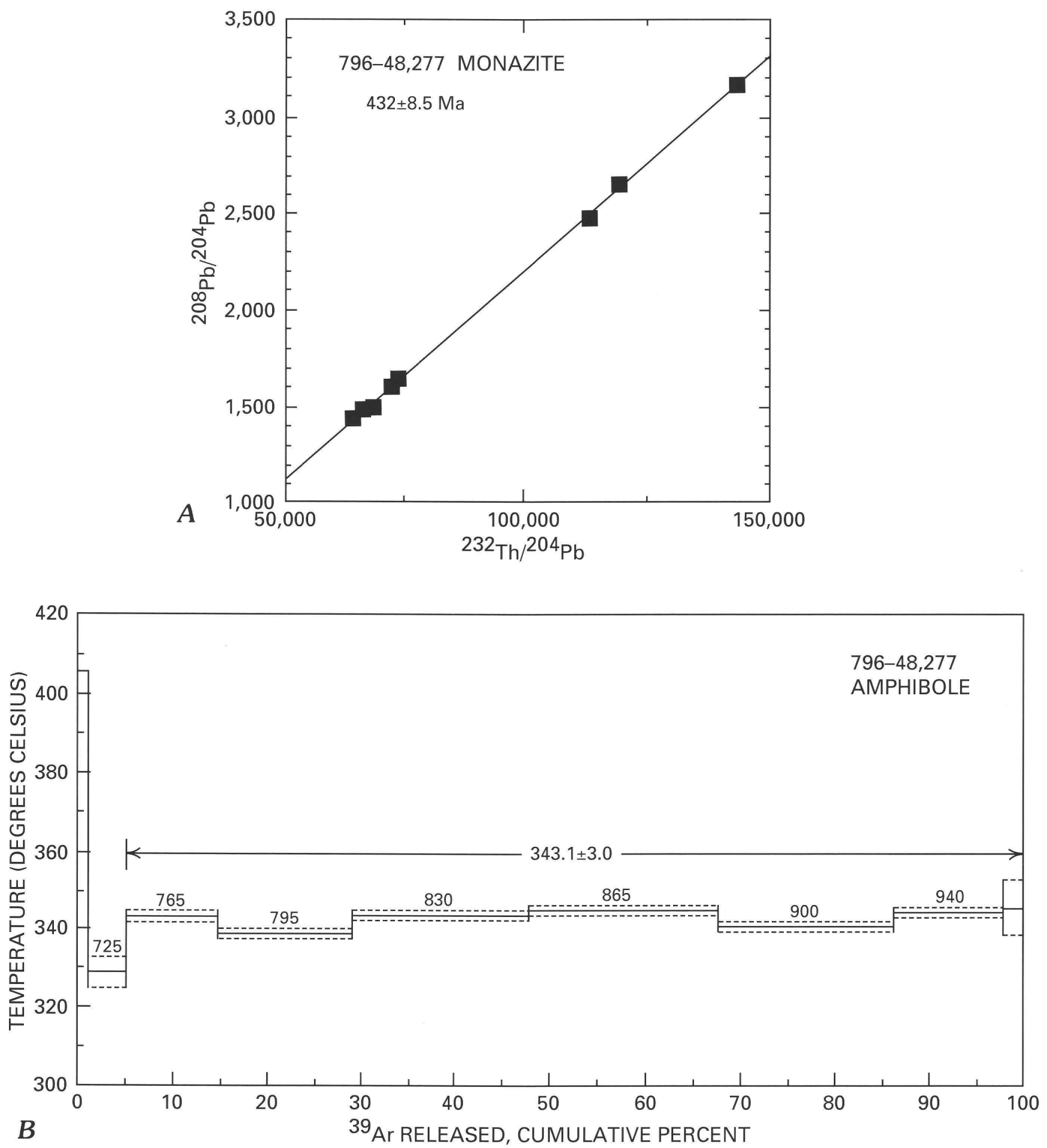

Figure 31. Radiometric ages of minerals in sample 796-48,277: A, Internal isochron showing mineral age of the monazite (432 $\pm 8.5 \mathrm{Ma}$ ), which replaced the host limestone marble and occurs as abundant inclusions in alkali amphibole; $B,{ }^{40} \mathrm{Ar} /{ }^{39} \mathrm{Ar}$ plateau showing age $(343.1 \pm 3.0 \mathrm{Ma})$ of the coexisting alkali amphibole that replaced the monazite. 

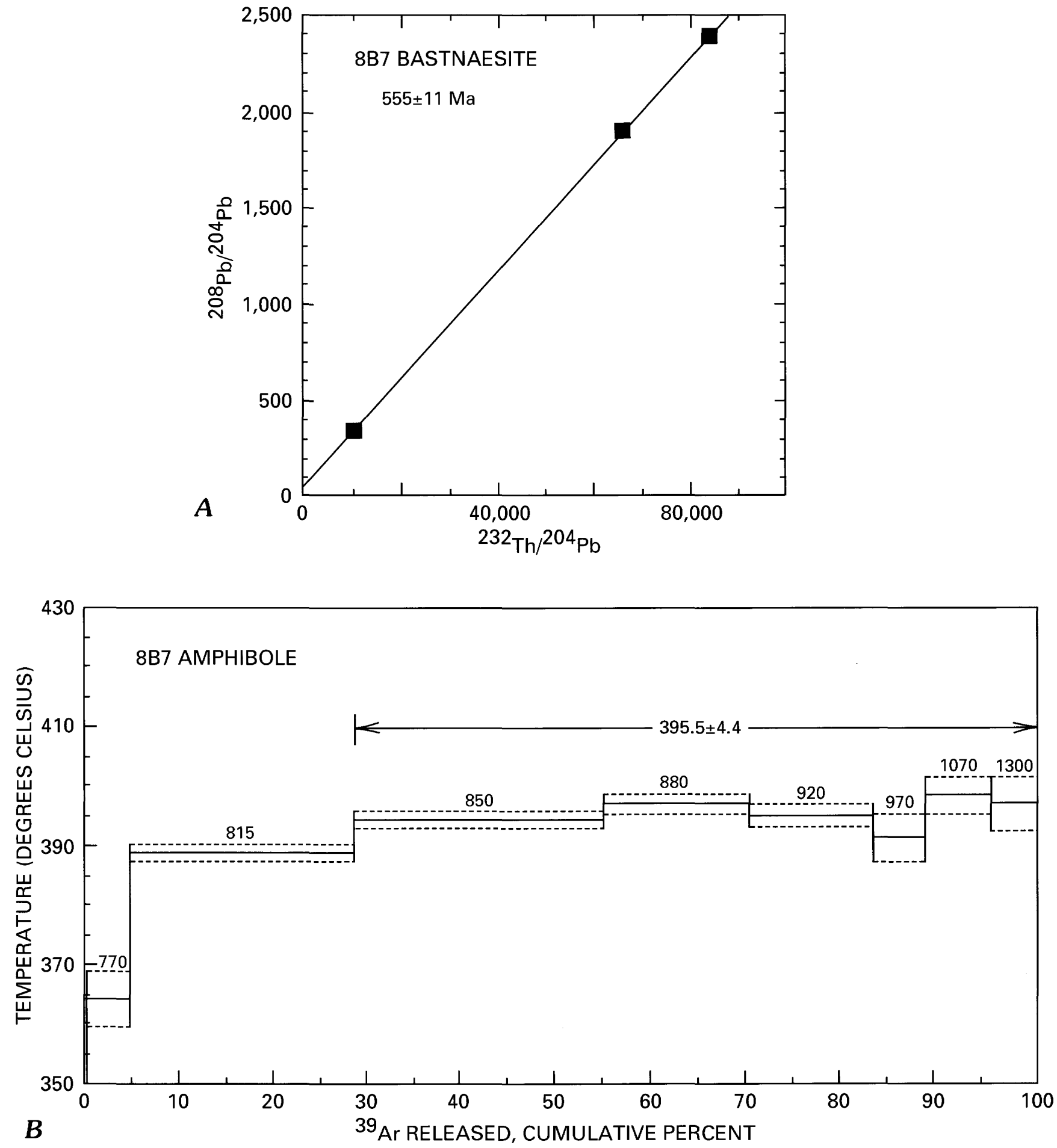

Figure 32. Radiometric ages of minerals in sample 8B7: $A$, Internal isochron showing mineral age of the bastnaesite (555 $\pm 11 \mathrm{Ma}$ ), which replaced the host dolostone marble; $B,{ }^{40} \mathrm{Ar} /{ }^{39} \mathrm{Ar}$ plateau showing age $(395.5 \pm 4.4 \mathrm{Ma})$ of the coexisting alkali amphibole. 


\section{Nb MINERALIZATION}

Because of the very fine grained nature of most of the $\mathrm{Nb}$ minerals and our limited resources, only fragmentary data on the occurrence of $\mathrm{Nb}$-bearing minerals are presented here. The most important $\mathrm{Nb}$ mineralization in the mine area is associated with the West Orebodies, which are west of the Main Orebody. Most of the $\mathrm{Nb}$ minerals occur as disseminated ores. Nb-rutile is closely associated with granular hematite in banded ores near the footwall of the Main Orebody, and columbite (table 1), the main $\mathrm{Nb}$ ore mineral, is closely associated with fresh magnetite in disseminated magnetite ores hosted by marble and dominated by alkali amphibole. Aeschynite (table 1 ) is the only coarsegrained $\mathrm{Nb}$ mineral that occurs in veins and is associated with huanghoite and alkali amphiboles. Pyrochlore (table 1), which is the dominant and typical $\mathrm{Nb}$ mineral associated with igneous carbonatites, is not a common $\mathrm{Nb}$ mineral in Bayan Obo, except in marble in contact with the Hercynian granodioritic rocks in the eastern part of the mine area. Preliminary fragmentary data indicate that the $438.2 \pm 25.1 \mathrm{Ma}$ age of vein aeschynite (Chao and others, 1993), a niobate mineral, may represent the earliest known age of $\mathrm{Nb}$ mineralization. The latest age of $\mathrm{Nb}$ mineralization is based on the occurrence of pyrochlore in skarn marble that is in contact with Hercynian biotite granodiorite, which occurs about $2 \mathrm{~km}$ east of the East Orebody.

\section{RADIOMETRIC AGES OF ALKALI AMPHIBOLES AS A KEY TO DETERMINING PERIODS OF REGIONAL METAMORPHISM AND HYDROTHERMAL ACTIVITIES}

The regional metamorphic and hydrothermal histories and the evolution of the Bayan Obo ore deposit are very complex. A general representation of this development is presented schematically in figure 33. Data on episodes of REE and Fe mineralization have already been described. Alkali amphiboles were used to decipher the complex metamorphic and metasomatic episodes of Bayan Obo. Three types of alkali amphiboles, namely, metamorphic, metasomatic, and metasomatic-metamorphic, were dated. Alkali amphiboles of these three origins were differentiated on the basis of texture and abundance. Amphiboles of regional metamorphic origin occur as prismatic and fibrous or asbestiform crystals disseminated within or linearly aligned along foliation planes in the $\mathrm{H} 8$ marble host rocks, and usually show some sign of deformation, such as strong wavy extinction or bent asbestiform. Metasomatic alkali amphiboles generally occur in ore hosted by $\mathrm{H} 8$ and locally may replace more than 10-50 volume percent of the host rock. The alkalis, $\mathrm{Fe}$, and $\mathrm{Si}$ necessary to form the amphibole were derived from hydrothermal solutions. Metasomaticmetamorphic alkali amphiboles are represented by large quantities of linearly aligned alkali amphiboles within and replacing the host marbles. Many metasomatic-metamorphic alkali amphiboles have magnesio-arfvedsonite prismatic cores thinly rimmed with magnesio-riebeckite (for example, samples 7B34-1P and 7B34-1F, table 15).

Samples representing different generations of these three types of alkali amphiboles vary in the $\mathrm{FeO} / \mathrm{MgO}$ ratios and in amounts of $\mathrm{MnO}$ and alkalis. All Bayan Obo alkali amphiboles are characteristically low in $\mathrm{Al}_{2} \mathrm{O}_{3}$. Generally, the chemical compositions of metamorphic alkali amphiboles are richer in $\mathrm{MgO}$ than $\mathrm{FeO}$, whereas the hydrothermal metasomatic alkali amphiboles are richer in $\mathrm{FeO}$ than $\mathrm{MgO}$.

\section{PERIODS OF REGIONAL METAMORPHISM}

Previous and contemporary studies of Inner Mongolia indicate that several periods of regional metamorphism could have occurred in the Bayan Obo region. For central Inner Mongolia, Tang and Yan (1993) recognized four different periods of regional metamorphism-Middle Proterozoic, early Paleozoic (two stages), and late Paleozoic. The two stages of early Paleozoic metamorphism were (1) subduction zone metamorphism that resulted in paired metamorphic belts in the Ondor Sum (Wenduermiao) ophiolite (fig. 4) and the Bainaimiao island arc complex, and (2) orogenic metamorphism that occurred during the collision of an island arc with the continent (North China craton). According to Tang and Yan, the Middle Proterozoic and late Paleozoic metamorphic events were associated with rifting and were characterized by low-pressure metamorphic facies. Zhang and Tao (1986) recognized two stages of Hercynian granite rocks; biotite ages show the early stage of 311-306 Ma and the later stage of 258-234 Ma.

We recognize three stages of regional metamorphism (fig. 33) in the Bayan Obo mine region (Conrad and others, 1991; Chao and others, 1995): Late Proterozoic (about 900 Ma), Silurian to Mississippian (Caledonian, 425-343 Ma), and Pennsylvanian to Triassic (Hercynian, 310-220 Ma). On the basis of the presence of alkali amphiboles of metamorphic origin, the degree of metamorphism during the Late Proterozoic and Caledonian events was probably equivalent to low-grade amphibolite facies. For Hercynian rocks, the presence of metamorphic biotite indicates a greenschist facies of regional metamorphism.

Late Proterozoic regional metamorphism converted $\mathrm{H} 8$ carbonate to marble and sandstone to quartzite. The marble and quartzite show poorly to well-developed triplejunction grain boundary textures, the result of mylonitization and recrystallization. Coarse-grained ferroan dolomite in $\mathrm{H} 8$ dolostone marble was strongly twinned and stretched, 


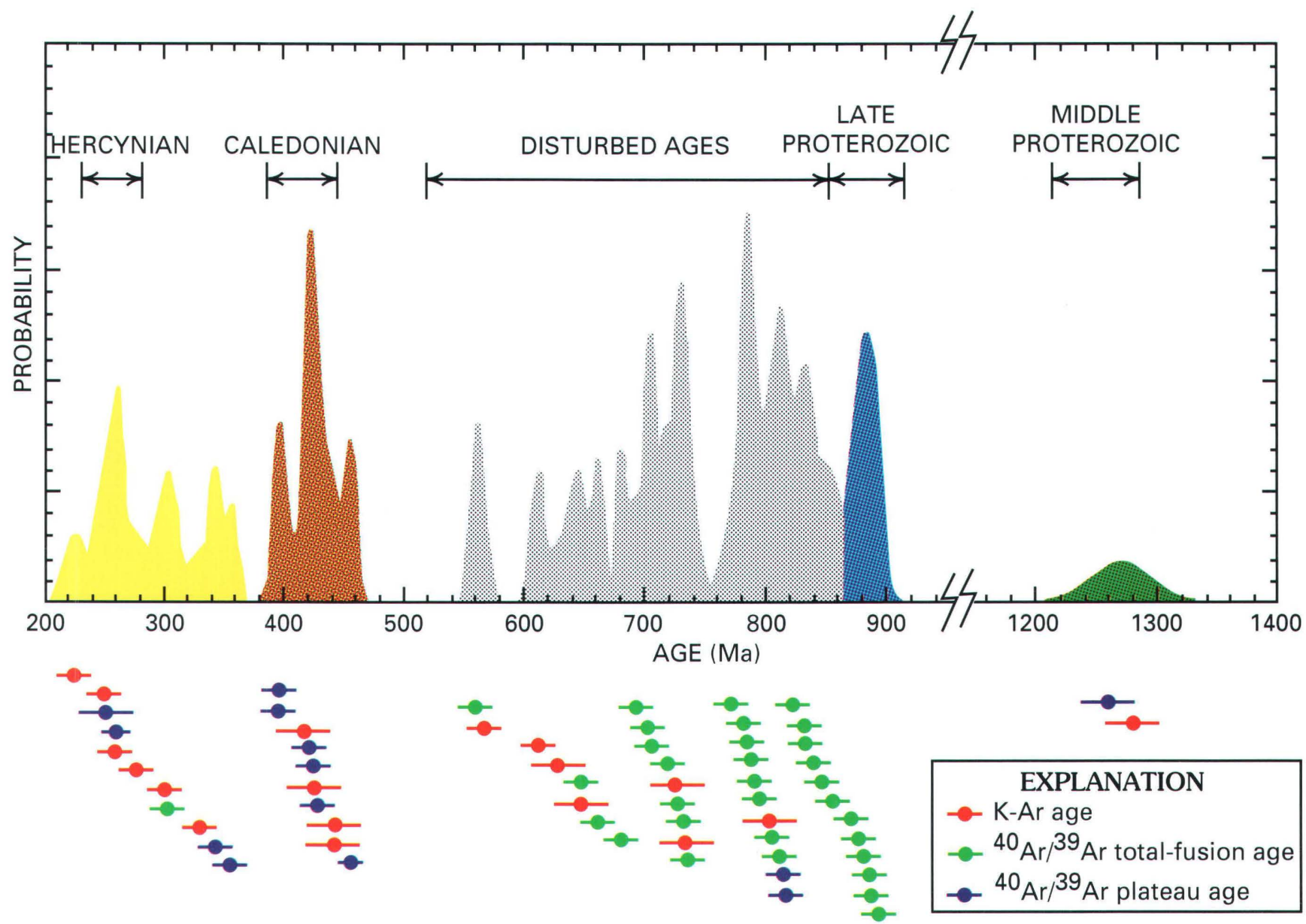

Figure 33. $\mathrm{K}-\mathrm{Ar}$ and ${ }^{40} \mathrm{Ar} /{ }^{39} \mathrm{Ar}$ minimum mineral ages of alkali amphiboles of both metasomatic and metamorphic origin from samples of the Bayan Obo REE-Fe-Nb ore deposit, Inner Mongolia, China.

and prismatic alkali amphiboles crystallized parallel to the direction of carbonate stretching within and along foliation planes in the marble. The minimum age of this event of regional metamorphism, based on single-grain, laser totalfusion ${ }^{40} \mathrm{Ar} /{ }^{39} \mathrm{Ar}$ analyses of lineated magnesio-arfvedsonite prismatic crystals in coarse-grained $\mathrm{H} 8$ dolostone marble (samples 40-14 and 8B24-1, table 15) is about $890 \mathrm{Ma}$. The chemical compositions of these magnesio-arfvedsonites from coarse-grained $\mathrm{H} 8$ dolostone marble are characterized by $\mathrm{MgO}>\mathrm{FeO}$, about 2-3 wt. percent $\mathrm{K}_{2} \mathrm{O}$, and about 2.2-2.5 wt. percent $\mathrm{F}$.

The Caledonian regional metamorphic event began at about $425 \mathrm{Ma}$ and continued until at least $395 \mathrm{Ma}$, based on ${ }^{40} \mathrm{Ar} /{ }^{39} \mathrm{Ar}$ ages of amphiboles. The $425 \mathrm{Ma}$ age is based on two types of metasomatic-metamorphic alkali amphiboles that occur in fine-grained to very fine grained, distinctly foliated, dolostone marble (samples 7B34-1F and 7B34-1P, table 15). One type of amphibole occurs as fine- to mediumgrained prismatic magnesio-arfvedsonite crystals (7B34$1 \mathrm{P})$ and the other as extremely fine grained asbestiform magnesio-riebeckite crystals (7B34-1F). The prismatic crystals are zoned or rimmed with magnesio-riebeckite that has a composition identical to the coexisting asbestiform magnesio-riebeckite. The ${ }^{40} \mathrm{Ar} /{ }^{\beta 9} \mathrm{Ar}$ plateau age of the prismatic crystals analyzed with the rim intact is $424.8 \pm 2.4 \mathrm{Ma}$, and the ${ }^{40} \mathrm{Ar} /{ }^{39} \mathrm{Ar}$ plateau age of the asbestiform magnesioriebeckite is $428.0 \pm 7.3 \mathrm{Ma}$, which is indistinguishable from that of the prismatic amphibole. Because of the large amounts of alkali amphiboles present, particularly the asbestiform variety, we interpret this mineral occurrence to be of metasomatic-metamorphic origin. The chemical composition of the prismatic amphibole (sample 7B34-1P) is much more sodic than the asbestiform variety, which is distinctly more calcic; both varieties of amphibole are higher in $\mathrm{MgO}$ than $\mathrm{FeO}$ (table 15). Caledonian metamorphism continued to at least about $395 \mathrm{Ma}$, based on the ${ }^{40} \mathrm{Ar} /{ }^{39} \mathrm{Ar}$ plateau age of coarse, bent, asbestiform blue-green amphibole in a 2- to 3-cm-wide vein that crosscuts banded ore (sample 7B30-30, table 15). This amphibole is oriented normal to the wall of the vein, has $\mathrm{a}^{40} \mathrm{Ar} /{ }^{\beta 9} \mathrm{Ar}$ plateau age of $395.8 \pm 6.2 \mathrm{Ma}$, and is characterized by a $\mathrm{MgO}$ content slightly higher than that of $\mathrm{FeO}$. On the basis of the age of 
this alkali amphibole, the Bayan Obo banded ores are interpreted to have formed before $400 \mathrm{Ma}$.

In addition to the widespread occurrence of Hercynian biotite granites and granodiorites in the Bayan Obo region, evidence for the Hercynian regional metamorphism is based on ${ }^{40} \mathrm{Ar} /{ }^{\beta 9} \mathrm{Ar}$ single-grain total-fusion analyses of biotite from $\mathrm{H} 9$ biotite schist, which was reset and yielded ages ranging from $309.8 \pm 5.8$ to $297.1 \pm 5.2 \mathrm{Ma}$. The ${ }^{40} \mathrm{Ar} /{ }^{39} \mathrm{Ar}$ plateau age of the Hercynian granodiorite, based on a single biotite sample, is $259.0 \pm 3.1 \mathrm{Ma}$. A sample of $\mathrm{K}$-feldspar from a pegmatite dike crosscutting $\mathrm{H} 9$ biotite schist gave a $\mathrm{K}$-Ar age of $225 \pm 7 \mathrm{Ma}$.

The occurrence of post-Caledonian or late Caledonian or early Hercynian low-grade regional metamorphism was also needed to account for the widespread presence of microchevron folds in banded ores and the recrystallized triple-junction grain boundary textures observed in some of the very fine grained REE and gangue minerals (apatite, barite, and fluorite) within bands of the banded ores. This period of low-grade regional metamorphism probably occurred before the main stage of fresh magnetite mineralization because fresh magnetite replaces folded banded ores, as shown in figure 29. Hercynian regional metamorphism also accounts for the isoclinal and chevron folds that are widespread in the $\mathrm{H} 9$ biotite schists with limestone boudinage. Clearly, the episodes of magnetite and $\mathrm{Nb}$ mineralization and the range of Hercynian regional metamorphism are complex and require more detailed study.

\section{PERIODS OF HYDROTHERMAL ACTIVITIES}

Magnesio-riebeckite from a vein crosscutting H6 quartzite (sample Drew 1, table 15) gave a disturbed ${ }^{40} \mathrm{Ar} /$ ${ }^{39} \mathrm{Ar}$ spectrum inferred to reflect an age of $1.26 \mathrm{Ga}$ (Conrad and McKee, 1992) and is the earliest evidence of hydrothermal activity in the Bayan Obo region. This magnesioriebeckite is high in $\mathrm{FeO}$ (22.74 wt. percent) and low in $\mathrm{MgO}$ (10.28 wt. percent) and $\mathrm{K}_{2} \mathrm{O}$ (1.03 wt. percent). The next period of hydrothermal activity in the mine area that we were able to document is indicated by magnesio-arfvedsonite from a vein (sample 7B13C, table 15) that also crosscuts the H6 quartzite in the West Orebodies region, about $5.2 \mathrm{~km}$ west-southwest of the west end of the Main Orebody. Prismatic alkali amphibole from this vein gave a disturbed ${ }^{40} \mathrm{Ar} /{ }^{39} \mathrm{Ar}$ plateau age of $820 \mathrm{Ma}$. The disturbance suggests that the age should be considered a minimum age of vein formation. The chemical composition of this magnesio-arfvedsonite has nearly equal amounts of $\mathrm{FeO}$ and $\mathrm{MgO}$ (14.15 and 14.95 wt. percent, respectively), 1.95 wt. percent $\mathrm{K}_{2} \mathrm{O}$, and 2.03 wt. percent $\mathrm{F}$.

Based on textural evidence and abundance, alkali amphibole of hydrothermal metasomatic origin occurs in marble-hosted disseminated $\mathrm{Fe}$ ore samples 8B42; 796-
48,252; 796-48,366; 8B7; and 796-48,277. The disseminated ores contain relicts of the marble host, small amounts of monazite or bastnaesite, and abundant alkali amphibole and magnetite. Apatite occurs locally. Chemically, these alkali amphiboles are generally slightly richer in $\mathrm{FeO}$ than $\mathrm{MgO}$ and contain from 1.77 to 3.28 wt. percent $\mathrm{CaO}$. Alkali amphibole from sample 8B42 contains 2.82 wt. percent $\mathrm{MnO}$ (table 15), whereas alkali amphiboles from samples $796-48,366$ and $796-48,277$ are uniquely high in $\mathrm{MnO}$ (4.91 and 5.68 wt. percent, respectively, table 15). Alkali amphibole from sample $8 \mathrm{~B} 42$ has a K-Ar age of $442 \pm 11$ $\mathrm{Ma}$, determined by the Tianjin laboratory. The ${ }^{40} \mathrm{Ar}{ }^{\beta 9} \mathrm{Ar}$ plateau ages of alkali amphibole from samples 796-48,252, 8 B7, and 796-48,277, obtained by Conrad and McKee, are $419.5 \pm 2.0,395.5 \pm 4.4$, and $343.1 \pm 3.0 \mathrm{Ma}$, respectively (table 15). The high $\mathrm{MnO}$ content of metasomatic alkali amphiboles generally seems to be characteristic of latestage Fe mineralization. On the basis of textural relations for all these samples of marble-hosted disseminated ore, alkali amphiboles replaced small amounts of monazite, and the amphibole, in turn, was replaced by magnetite. Therefore, the magnetite mineralization may be younger than the youngest $(343.1 \pm 3.0 \mathrm{Ma})$ metasomatic alkali amphiboles (sample 796-48,277).

The ages of metasomatic alkali amphiboles correspond to episodes of intense hydrothermal activity in the Bayan Obo mine area, when most of the REE mineralization of banded ores took place. However, because the episodes are represented by different mineral assemblages, the mineralizing fluids for the metasomatic amphiboles and banded ores may have been unrelated. Many of the banded ores having high $\mathrm{RE}_{2} \mathrm{O}_{3}$ contents do not contain alkali amphiboles. As previously mentioned, where REE minerals coexist with alkali amphiboles in marble-hosted disseminated ores, the monazite and bastnaesite are usually much older than the alkali amphiboles, for example, in samples 8B7 and 796-48,277 (tables 14 and 15). Hornblende from a plagioclase-hornblende vein that crosscuts banded ore has a ${ }^{40} \mathrm{Ar} /{ }^{39} \mathrm{Ar}$ plateau age of $355.1 \pm 4.8 \mathrm{Ma}$, which together with the age of alkali amphibole from a vein that crosscuts banded ore (sample 7B30-30), indicates that all banded ores in the Main and the East Orebodies were formed before about $396 \mathrm{Ma}$, the metamorphic age of the older amphibole.

\section{REMOBILIZATION AND METAMORPHIC EFFECTS ON MINERAL AGES}

Chao and others (1993) determined that remobilization of monazite was unlikely because any metal-transporting acid hydrothermal solutions entering along microfractures and grain boundaries within the carbonate host rock would tend to dissolve and remove the carbonate host, become neutralized, and precipitate the metals and other mineral components from such solutions. To a very minor extent, 
bands of fluorite in banded ores do show slight resorption of early minerals such as REE, Fe oxide, and gangue minerals, but resorption is limited to within the band itself. Therefore, remobilization and redistribution of early REE minerals and alkali amphibole are likely to have been minimal or insignificant.

The effect of metamorphism on mineral ages was estimated by Chao and others $(1992,1993)$. Metamorphism did not cause resetting of the ages of various generations of REE minerals because closure temperatures of monazite are higher than the temperatures reached during the low-grade Caledonian and Hercynian thermal events. Harland and others (1990) stated that the U-Th-Pb system closure temperature for monazite is in the range $600-500^{\circ} \mathrm{C}$ for cooling rates of $10-1{ }^{\circ} \mathrm{C} / \mathrm{m} . \mathrm{y}$. , and Parrish (1990) cited a $725 \pm 25^{\circ} \mathrm{C}$ closure temperature for the $\mathrm{U}-\mathrm{Pb}$ system in monazite. The ${ }^{232} \mathrm{Th} /{ }^{208} \mathrm{~Pb}$ internal isochrons of monazites and bastnaesites (figs. 18-22, 31A, and 32A; Wang and others, 1994) indicate no resetting of mineral ages.

According to Harrison (1981), the closure temperatures of hornblende are $578-490^{\circ} \mathrm{C}$ for cooling rates in the range $500-5^{\circ} \mathrm{C} / \mathrm{m}$.y. The ages of alkali amphiboles from samples Drew 1 and 7B13C have been slightly disturbed, probably by the latest Caledonian events. Conrad and McKee (1992) found a 10-percent decrease of the age of Drew 1 due to ${ }^{40} \mathrm{Ar}$ loss. Multiple analyses of alkali amphibole subsamples from a vein (sample 7B13C, table 15) have disturbed ${ }^{40} \mathrm{Ar} /{ }^{\beta 9} \mathrm{Ar}$ spectra, the apparent ages ranging from about 820 to $640 \mathrm{Ma}$ (fig. 33). The age of $820 \mathrm{Ma}$ is considered the minimum age of this alkali amphibole. Because of evidence of disturbance of pre-Caledonian alkali amphiboles due to ${ }^{40} \mathrm{Ar}$ loss, mineral ages of various generations of alkali amphiboles are considered minimum ages. However, the Caledonian ages for alkali amphiboles of various origins generally show good to excellent ${ }^{40} \mathrm{Ar} /{ }^{39} \mathrm{Ar}$ plateau release patterns (figs. $31 B$ and $32 B$; Chao and others, 1993). Because of the good to excellent plateau release patterns of Caledonian-age alkali amphiboles, these alkali amphiboles do not appear to have been seriously affected by thermal events associated with the intrusion of granitic rocks or regional metamorphic events of Hercynian age.

In comparison with hornblende, biotite has a much lower estimated closure temperature, about $345-280^{\circ} \mathrm{C}$ for cooling rates in the range $100-1{ }^{\circ} \mathrm{C} / \mathrm{m}$.y. (Harrison and others, 1985). The biotite in biotite and albitized-biotite schists of the H9 lithologic unit has been reset and has ${ }^{40} \mathrm{Ar} /{ }^{\beta 9} \mathrm{Ar}$ single-crystal total-fusion ages ranging from $309.8 \pm 5.8 \mathrm{Ma}$ to $297.1 \pm 5.2 \mathrm{Ma}$. It is likely that the Hercynian granitic intrusion and regional metamorphic events have reset all biotite ages in the Bayan Obo mine region.

\section{MINERAL PARAGENETIC SEQUENCE}

The key evidence for the epigenetic origin of the Bayan Obo ore deposit, in addition to the mineral textural relations, lies in the precise ages of episodes of mineralization of various generations of monazites and bastnaesites, and the minimum mineral ages of alkali amphiboles (fig. 33). The more than 100 carefully chosen doubly polished thin sections that were studied in detail provided the textural relations of both gangue and ore minerals replacing not only the host rocks but also ore and gangue minerals in various assemblages of disseminated and banded ores. A few of the selected replacement textures are shown in figures 14-17. Such textural data are corroborated with chemical compositions and isotopic mineral ages of the various generations of both alkali amphiboles and REE minerals. The resulting generalized mineral paragenetic sequence, updated from Chao and others (1993), is given in table 13. 



\section{Part II. CALEDONIAN SUBDUCTION AS A POSSIBLE CAUSE AND MECHANISM OF REPEATED HEATING, FRACTURING, AND HYDROTHERMAL MINERALIZATION}

\section{SUBDUCTION OF THE MONGOLIAN PLATE}

Subduction of the Mongolian oceanic plate during Caledonian time (about 555-396 Ma) may have been a mechanism for repeated heating, fracturing, and hydrothermal mineralization at Bayan Obo (Chao and others, 1995). The tectonic setting of the region that includes the Bayan Obo mine area was discussed by Zhao and Li (1987), Wang and others (1991), and Tang and Yan (1993). These three reports do not fully agree in either description or available isotopic age data. As a consequence, the history and ages of tectonic development and regional metamorphism of Inner Mongolia remain obscure. Zhao and $\mathrm{Li}$ (1987) outlined a five-stage plate tectonic model for the North China cratonal margin in Inner Mongolia during the Paleozoic (fig. 34). As a result of oceanic spreading, the Mongolian oceanic plate moved southward during the Paleozoic, causing two episodes of subduction of the Mongolian oceanic plate underneath the North China cratonal margin. The earliest subduction began at the end of the Xin Kai stage of the late Early Cambrian and possibly extended to the early Caledonian. This period of subduction shortened the eugeosynclinal sedimentary sequence of the Xin Kai stage and was accompanied by continental granitic intrusions. The second phase of subduction was near the end of the Middle Silurian and consisted of high-angle rapid subduction of the Mongolian plate, resulting in formation of the Bainaimiao island arc and accompanying island-arc granitic rocks.

Wang and others (1991) described, as resulting from subduction, a 1,800 -m-thick ophiolite unit that extends east-west for a distance of about $100 \mathrm{~km}$ at Ondor Sum (Wenduermiao), about $275 \mathrm{~km}$ east-northeast of Bayan Obo (fig. 4). This ophiolite unit consists, in ascending order, of $200 \mathrm{~m}$ of metamorphosed harzburgite, $400 \mathrm{~m}$ of cumulate gabbros, $200 \mathrm{~m}$ of sheeted diabase dikes, $500 \mathrm{~m}$ of basic pillow lavas, and $500 \mathrm{~m}$ of abyssal sedimentary rocks. Wang and others (1991) reported that fossils found in the abyssal sedimentary rocks are late Paleozoic to Cambrian in age, the $\mathrm{K}$-Ar age of amphibole in metagabbro is 632-626 Ma, and the metamorphic age of blueschists in the ophiolite series is $435 \pm 61 \mathrm{Ma}$. The ophiolite sequence is unconformably overlain by Upper Silurian beds containing coral fossils.

Two types of granitic rocks are associated with the gabbroic rocks of the ophiolite sequence found in the Ondor
Sum region between Tulinkai and Deyenqimiao. One type consists of small bodies of grayish-white, very fine grained plagioclase granite, containing about 60 volume percent of oligoclase-andesine plagioclase feldspars, about 30 volume percent quartz, 5 percent $\mathrm{K}$-feldspars, 1 percent biotite, and accessory amounts of zircon and magnetite (Zhao and $\mathrm{Li}$, 1987). The other type consists of rare exposures of granophyre associated with pillow lavas in the ophiolite suite. The granophyres are red and fine grained, having intergrowths of K-feldspar and quartz (15-20 volume percent), plagioclase with Carlsbad twins, and about 5-7 volume percent small scattered grains of quartz. The granophyre also contains 5-10 volume percent of dark minerals, mainly epidote and chlorite, and the accessory minerals magnetite, hematite, apatite, zircon, and rutile.

Tang and Yan (1993) compiled geologic and tectonic sketch maps of central Inner Mongolia and a model for the Proterozoic to middle Paleozoic plate tectonic evolution of the Inner Mongolian suture zone. They also described the ophiolite suite of the Ondor Sum (Wenduermiao) region and interpreted it to be a residual fragment of early Paleozoic oceanic crust. According to their description, the ophiolite consists of a lower ( $>700$-m-thick) gabbro and diabase, a middle sequence of sheeted dike swarms and pillow lavas, and an upper sequence of tuffaceous sediments and siliceous-argillaceous rocks. Tang and Yan further reported the metabasalt as having a $\mathrm{Rb}-\mathrm{Sr}$ (whole-rock isochron?) age of $509 \pm 40 \mathrm{Ma}$. However, east of Ondor Sum, in the Kedanshan-Wudaoshimen district on the northern side of the Xar Moron River, they found many ophiolite blocks containing chert with Ordovician microfossils.

Although more isotopic age data are needed, the simple model proposed by Zhao and Li (1987), slightly modified and reproduced in figure 34 , provides a hypothetical mechanism for repeated heating, fracturing, and hydrothermal mineralization that accounts for the episodes of REE mineralization of the giant Bayan Obo REE-Fe-Nb ore deposit. The Caledonian subduction can be traced for an east-west distance of a little more than $10^{\circ}$ longitude, or approximately $850 \mathrm{~km}$. The extent of Caledonian subduction is of interest with regard to other possible giant polymetallic ore deposits that are known or reported to occur along the northern margin of the North China craton. The more extensive Hercynian subduction occurred north of the trace of Caledonian subduction (fig. 4) and was accom- 


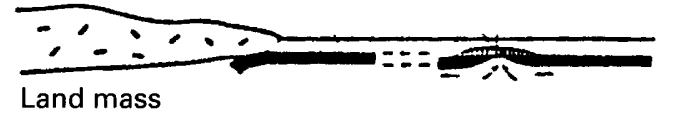

Initial ocean spreading stage

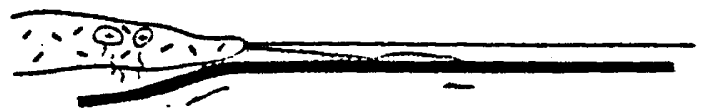

Early subduction stage

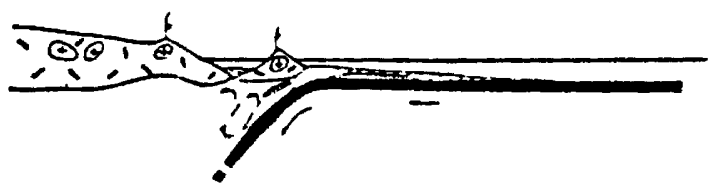

Arc-forming stage

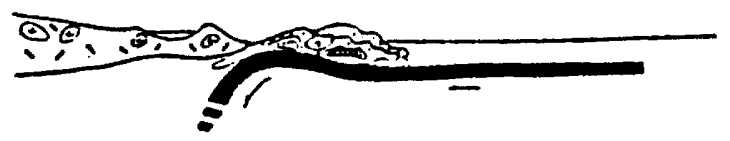

Late subduction stage

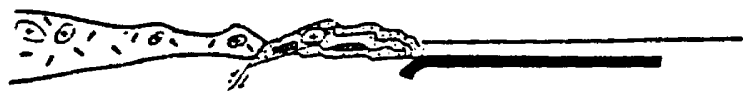

Terminal subduction stage

Figure 34. Schematic diagram proposed by Zhao and $\mathrm{Li}$ (1987), showing five stages of north to south subduction of the Siberian oceanic plate under the northern margin of the North China craton.

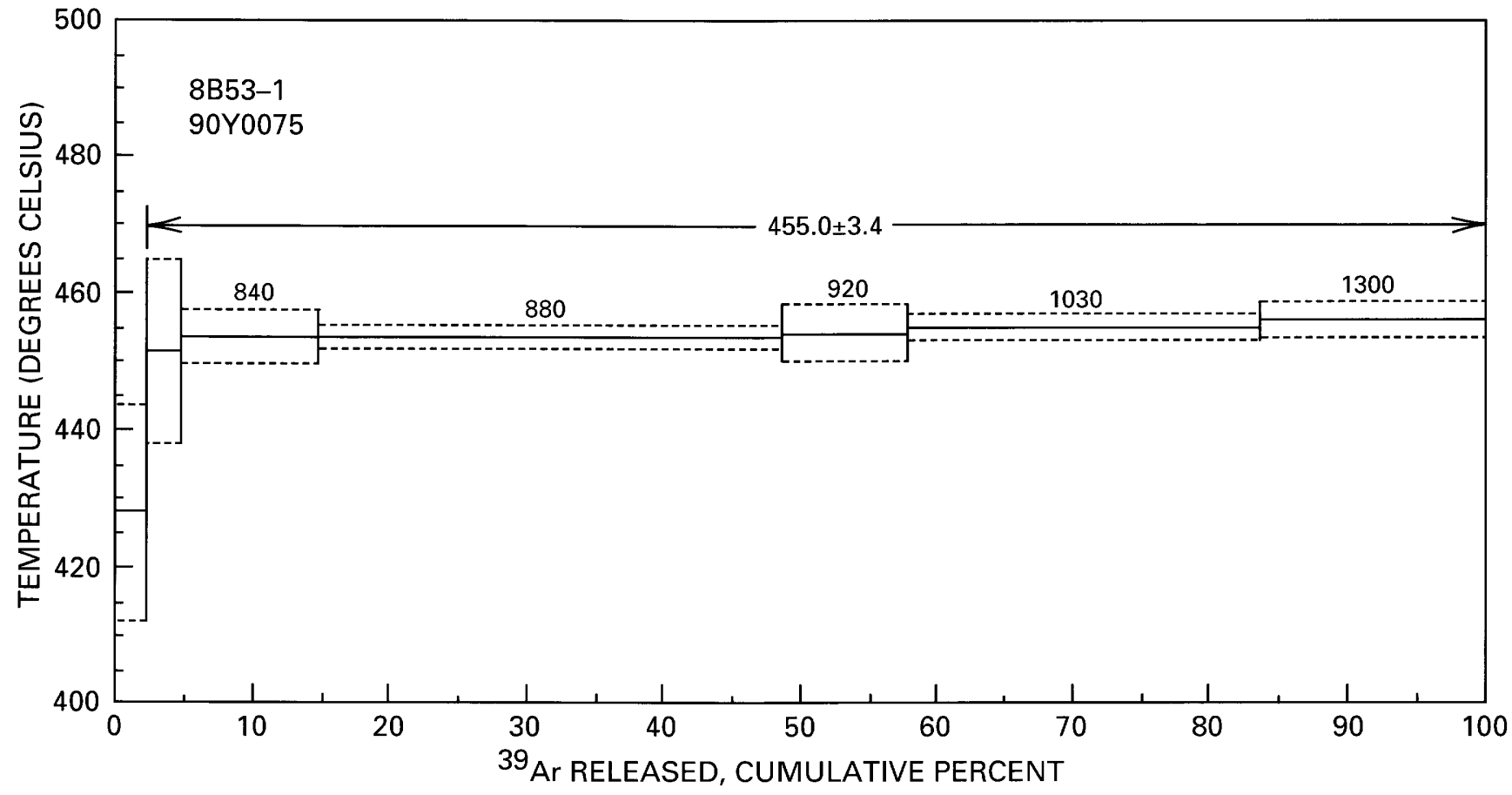

Figure 35. The ${ }^{39} \mathrm{Ar}$ release pattern of incremental heating of hornblende from a quartz monzonite rock, sample 8B53-1, collected near Hejao, showing a plateau ${ }^{40} \mathrm{Ar} /{ }^{39} \mathrm{Ar}$ Caledonian age of 455.0 $\pm 3.4 \mathrm{Ma}$ (J.E. Conrad and E.H. McKee, unpub. data, 1990). 
panied by widespread granitic intrusion. The importance of the Hercynian subduction with regard to metallogenic ore deposits has not been demonstrated.

The history of intermittent, episodic REE mineralization, based on the general paragenetic sequence and ages of mineralization, would require repeated and alternating periods of fracturing (tensional tectonics) and compression (regional metamorphism). Compression was required to produce heating and generation of hydrothermal solutions to scavenge and concentrate REE's from the deep crustal source area. Fracturing was required to provide channels for the hydrothermal solutions to ascend to near the surface to produce the giant Bayan Obo REE deposit.

\section{GENERATION OF THE CALEDONIAN HEJAO PLUTONIC ROCKS AND THE SOURCES OF METAL- BEARING HYDROTHERMAL SOLUTIONS}

An east-trending belt of granitic plutonic rocks about $20-30 \mathrm{~km}$ wide and at least $120 \mathrm{~km}$ long, about $50 \mathrm{~km}$ south of Bayan Obo (fig. 1) has a tentative Paleozoic (Caledonian) age based on the age of similar granitic rocks overlain by Silurian sedimentary rocks north of the Kuanggou fault. According to Zhao and $\mathrm{Li}$ (1987), these granitic rocks follow a deep major fault-fracture zone. They intruded metamorphic rocks of the Bayan Obo Group and were, in turn, intruded by Hercynian granitic rocks. The only petrographic description available for the rocks in this belt is that of Zhao and $\mathrm{Li}$ (1987), which shows the rocks to consist mainly of granodiorite, monzonitic granite, and quartz biotite diorite. The plutonic rocks are chiefly grayish to pale yellowish, fine to medium grained, and foliated and have poorly developed granular texture. Mineral compositions vary widely; the rocks consist of 45-65 volume percent plagioclase (oligoclase-andesine), 0-30 volume percent $\mathrm{K}$ feldspar (perthite), a few to 30 volume percent quartz, and 2-10 volume percent mafic minerals (biotite or hornblende). Accessory minerals are magnetite, ilmenite, zircon, apatite, garnet, and tourmaline.

We collected several samples of pink, medium-grained quartz monzonite or monzonitic granite (for example, sample 8B53-1) from outcrops near Hejao (fig. 1). They contain fresh black hornblende $0.5-1 \mathrm{~cm}$ across and scattered small zircon crystals. The ${ }^{39} \mathrm{Ar}$ incremental heating release pattern of hornblende from sample 8B53-1 shows a plateau age of $455.0 \pm 3.4 \mathrm{Ma}$ (fig. 35; J.E. Conrad and E.H. McKee, unpub. data, 1990). Thirteen small zircon crystals were also separated from this sample. The best estimated U-Pb age of the zircon, $451 \pm 17 \mathrm{Ma}$ (see details in Wang and others, 1994), is in good agreement with the ${ }^{40} \mathrm{Ar} /{ }^{39} \mathrm{Ar}$ age of Ordovician (Caledonian) hornblende.
Zhao and Li (1987, table 1) also published several chemical analyses of the granitic rocks of Hejao. Among them are two analyses with high total alkalis (values in wt. percent):

\begin{tabular}{|c|c|c|}
\hline & \multicolumn{2}{|c|}{ Sample number } \\
\hline & 513 & 415 \\
\hline $\begin{array}{l}\mathrm{SiO}_{2} \\
\mathrm{TiO}_{2} \ldots \ldots \ldots \ldots \\
\mathrm{Al}_{2} \mathrm{O}_{3} \\
\mathrm{Fe}_{2} \mathrm{O}_{3} \\
\mathrm{FeO}\end{array}$ & $\begin{array}{r}77.31 \\
.05 \\
11.47 \\
.37 \\
.41\end{array}$ & $\begin{array}{r}75.72 \\
.16 \\
13.26 \\
.15 \\
.45\end{array}$ \\
\hline 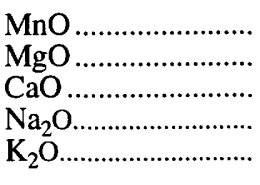 & $\begin{array}{r}.02 \\
.35 \\
.19 \\
1.82 \\
7.27\end{array}$ & $\begin{array}{l}.02 \\
.33 \\
.51 \\
1.88 \\
6.60\end{array}$ \\
\hline $\begin{array}{l}\mathrm{P}_{2} \mathrm{O}_{5} \\
\text { Loss on ignition ...... }\end{array}$ & $\begin{array}{l}.00 \\
.24\end{array}$ & $\begin{array}{l}.00 \\
.55\end{array}$ \\
\hline
\end{tabular}

According to Eby (1990), A-type (denoting either anorogenic or anhydrous) granitoids are characterized by their relatively high alkali contents, low $\mathrm{CaO}$ contents (at $\mathrm{SiO}_{2}>70$ percent; $\mathrm{Na}_{2} \mathrm{O}+\mathrm{K}_{2} \mathrm{O}=7-11$ percent, and $\mathrm{CaO}<1.8$ percent), and high $\mathrm{FeO} / \mathrm{MgO}$ values. A-type granitic rocks were emplaced into non-orogenic settings, both within crustal plates and along plate margins, during the waning stages of subduction-zone-related magmatism. The above chemical compositions of Hejao granite samples 513 and 415 meet the criteria of high total alkalis at $\mathrm{SiO}_{2}$ greater than 70 percent, and low $\mathrm{CaO}$ content, but they do not meet the criterion of high $\mathrm{FeO} / \mathrm{MgO}$ values. Zhao and $\mathrm{Li}$ (1987) classified three other granitic rocks as S-type granites. On the basis of the average $\delta^{18} \mathrm{O}$ value of 10.55 per mil (\%o) for whole-rock analyses of three Hejao types of granitic rocks, Zhao and $\mathrm{Li}$ concluded that they are characteristic of continental crustal origin. The Hejao granitic rocks, however, contain a total REE content ranging from 36 to $58 \mathrm{ppm}$ (Zhao and $\mathrm{Li}, 1987$ ) and are unrelated to the hydrothermal sources rich in REE's for the REE mineralization of the Bayan Obo ore deposit.

The Hejao granitic plutonic complex should be studied in greater detail with regard to field occurrences, petrology, geochemistry, and isotopic geochronology. We suggest that the Hejao granitic plutonic rocks, an age of $455 \pm 3.4 \mathrm{Ma}$, and the hydrothermal solutions that were enriched in REE's could have been related to Caledonian subduction of the Mongolian-Siberian oceanic plate beneath the North China craton that occurred at 555-395 Ma, as outlined by Zhao and $\mathrm{Li}$ (1987) and Tang and Yan (1993). The crustal sources for the Hejao granitic rocks and the REE hydrothermal solutions may have been quite different because the Hejao granitic rocks are about $50 \mathrm{~km}$ south of the Bayan Obo mine region. 



\section{Part III. BAYAN OBO AS A CORNERSTONE EXAMPLE FOR STUDYING GIANT POLYMETALLIC ORE DEPOSITS OF HYDROTHERMAL ORIGIN}

Doe (1993) examined giant ore deposits using criteria parallel to evaluation of giant oil fields with respect to sources of the ore. Parameters related to the occurrence of giant ore deposits were also the subject of a workshop (Whiting and others, 1992).

In order to investigate, evaluate, and understand the characteristics favorable to the formation of giant and super giant polymetallic ore deposits of hydrothermal origin, regardless of the types of ores present, it is necessary to obtain pertinent data for the following parameters: (1) sources of the ores, (2) tectonic setting, (3) mechanism for concentrating and transporting the ore-bearing hydrothermal fluids, (4) mineral paragenetic sequence and geochemical evolution of the deposit, (5) mineral assemblages and the transport of ore by hydrothermal fluids, (6) age or ages of episodes of mineralization, (7) lithology of reservoir rocks favorable for hosting the ores, and (8) preservation of the ores. This spectrum of data may not be available for many giant or super giant ore deposits. Here, we focus the discussion of the above parameters on the basis of findings from the Bayan Obo giant ore deposit. We then cite for possible comparison the giant and super giant porphyry Cu-Mo deposits of Peru and Chile in South America. Although these are different types of deposits, they share some characteristics with Bayan Obo.

\section{SOURCES OF THE ORES}

Both the geologic setting and isotopic signatures of the REE ore minerals suggest a crustal source for REE. The formations underlying the Proterozoic Bayan Obo Group consist of Archean and Early Proterozoic granitic and migmatitic gneiss intruded by pegmatitic dikes and stocks. According to the Institute of Geochemistry (1988, p. 505), the Early Proterozoic granitic rocks and the widespread Early Proterozoic pegmatites contain relatively high contents of $\mathrm{RE}_{2} \mathrm{O}_{3}$, which for the granitic rocks range from 800 to $1,308 \mathrm{ppm}$, notably higher than the average of about 290 ppm $\mathrm{RE}_{2} \mathrm{O}_{3}$ for granitic rocks elsewhere. The granite-pegmatites in the area of Hayehhutung locally contain more than 10 volume percent allanites, some of which occur as round or lenticular bodies exceptionally high in LREE's (Zhao Zhenhua, oral commun., 1993). Some of the pegmatitic rocks contain $\mathrm{Nb}-\mathrm{Ta}$ minerals. The only direct evidence we found with regard to $\mathrm{RE}_{2} \mathrm{O}_{3}$ sources was the occurrence of above-normal concentrations of $\mathrm{RE}_{2} \mathrm{O}_{3}$ in detrital apatite (see sample 7B25-1, table 5) from coarse-grained H8 dolostone marble.

The abundance of allanite in Early Proterozoic rocks in the Bayan Obo area, and the widespread low- to minablegrade monazite disseminated in ores throughout the $16 \mathrm{~km}$ by $2-3 \mathrm{~km}$ extent of the mine region, led investigators of the Institute of Geochemistry (1988) to favor a syngenetic origin for the Bayan Obo REE ores. This interpretation is not supported by our studies (Chao and others, 1992, 1993; Wang and others, 1994; this paper).

$\mathrm{Pb}$ and $\mathrm{Nd}$ isotopes from Bayan Obo ore and gangue minerals, analyzed by Wang and others (1994), indicate a crustal origin for the REE's at Bayan Obo. Typically, the ${ }^{206} \mathrm{~Pb} /{ }^{204} \mathrm{~Pb}$ ratios are low and the ${ }^{208} \mathrm{~Pb} / 204 \mathrm{~Pb}$ ratios are high for the REE-bearing and REE minerals. In the same suite of REE minerals, $U$ is strongly depleted with respect to $T h$, and monazite, bastnaesite, REE-bearing apatite, and aegirine augite have high negative $\varepsilon_{\mathrm{Nd}}$ values $(-16$ to -19$)$. These isotopic signatures clearly indicate a crustal source for Bayan Obo REE ores.

\section{TECTONIC SETTING}

Caledonian subduction, related to REE mineralization at Bayan Obo, has been discussed in parts I and II (figs. 4 and 34).

\section{MECHANISM FOR CONCENTRATING THE ORES IN SOURCE RESERVOIRS}

We propose that the REE's and Fe were scavenged and concentrated from the underlying crust by acidic hydrothermal solutions activated by Caledonian subduction. In addition, repeated fracturing and shearing during the Paleozoic Era produced the channels for the hydrothermal solutions to bring the REE's and Fe from deep crustal source areas and deposit them mostly in the $\mathrm{H} 8$ host marble. On the basis of the experimental studies of Hemley and others (1992), we suppose that such long-distance travel by hydrothermal solutions enriched with scavenged REE's and Fe is feasible and probable. 


\section{MINERAL PARAGENETIC SEQUENCE AND GEOCHEMICAL EVOLUTION OF THE BAYAN OBO ORE DEPOSIT}

The geochemical evolution of the Bayan Obo ore deposit can be deduced from the paragenetic relations of the hydrothermal minerals (table 13). REE's evidently were the first ore elements introduced, at about $555 \mathrm{Ma}$, along with $\mathrm{P}$ and $\mathrm{F}$. The solutions containing these elements had random spatial and time distribution and produced disseminated ores containing monazite or bastnaesite or mixtures of these two major REE minerals. These disseminated REE ores were followed by the formation of REE banded ores, and later by $\mathrm{Fe}_{2} \mathrm{O}_{3}$ (hematite) ores, which together with martite and magnetite formed the massive $\mathrm{Fe}$ cores of the Main and East Orebodies.

During the peak periods of ore formation, REE's, $\mathrm{Fe}, \mathrm{P}$ (to form monazite and apatite), $\mathrm{Na}, \mathrm{Si}$ (to form aegirine augite), $\mathrm{F}$ (to form bastnaesite and fluorite), and $\mathrm{Ba}$ (to form barite) were brought in by different hydrothermal solutions in order to produce the wide variety of banded ores. $\mathrm{Na}, \mathrm{K}$, and Si (to form alkali amphiboles) were also introduced during the peak and waning phases of REE mineralization, but deposited in different parts of the orebodies than the above assemblage. During this period, $\mathrm{U}$ and $\mathrm{S}$ were uniquely missing as geochemical components.

During late-stage hydrothermal activities, $\mathrm{Nb}$ took on increasing importance. $\mathrm{Nb}$ accompanied and followed $\mathrm{Fe}$ mineralization, and was accompanied and followed by minor $S$ activity (to form gangue sulficies). The last stage of hydrothermal activity consisted of $\mathrm{Ba}$ and $\mathrm{K}$ metasomatism, which was widespread in the $\mathrm{H} 9$ biotite schist (Drew and others, 1990).

Geochemically, the Bayan Obo ore deposit was enriched by ore metals in the sequence REE's, $\mathrm{Fe}$, and $\mathrm{Nb}$; and the gangue elements $\mathrm{P}, \mathrm{F}$, and $\mathrm{Ba}$. Bayan Obo is characterized by the scarcity or lack of $\mathrm{U}, \mathrm{S}, \mathrm{Ta}, \mathrm{Al}$, the precious metals $\mathrm{Au}$ and $\mathrm{Ag}$, and base metals $\mathrm{Cu}, \mathrm{Pb}$, and $\mathrm{Zn}$.

\section{MINERAL ASSEMBLAGES AND THE TRANSPORT OF REE'S IN HYDROTHERMAL FLUIDS}

Humphries (1984) stated that transport of REE's in hydrothermal fluids for any great distance is probably accomplished by the formation of carbonate, fluoride, or sulfate complexes. In addition, experimental studies cited by Humphries (1984) indicate that for most REE's, $\mathrm{RE}(\mathrm{Cl}, \mathrm{F})_{2}{ }^{+}$has been identified as the most stable complex in acidic solutions rich in $\mathrm{Cl}^{-}$or $\mathrm{F}^{-}$ions, but $\mathrm{RE}(\mathrm{Cl}, \mathrm{F})_{3}$ is most stable for La. The presence of fluoride significantly increases the mobility of the REE's.
For the early stage of disseminated monazite in ores hosted by $\mathrm{H} 8$ marble, REE's clearly were associated with only $\mathrm{P}$ anions, and therefore the acidic REE hydrothermal solutions were enriched in P ions only. In the case of the early-stage precipitation of disseminated bastnaesite, $\mathrm{F}$ was introduced, so that the most stable complexes could have been $\mathrm{RE}(\mathrm{Cl}, \mathrm{F})_{2}{ }^{+}$and $\mathrm{RE}(\mathrm{Cl}, \mathrm{F})_{3}$

Monazite and bastnaesite in banded ores could also have resulted from precipitation of complex ions of carbonates or fluorides from the hydrothermal fluids; the bands of monazite and bastnaesite are probably unrelated to the associated fluorite bands, which are in general later in the paragenetic sequence of the assemblage. The early stage of disseminated REE mineralization and the peak period of REE mineralization in banded ores were apparently not related to any alkali cations because aegirine augite and alkali amphiboles, if present, always belong to later stages in the paragenetic sequence of those assemblages.

Although casual inspection of the complex Bayan Obo deposit may lead to the conclusion that the associations of alkali amphiboles, aegirine augite, and REE minerals are related to a carbonatite magma, the experimental data from Humphries (1984) and the younger ages of the amphiboles and augite with respect to associated REE minerals refute this. Multiple episodes of REE mineralization span a period of about $\mathbf{1 5 0}$ million years at Bayan Obo (Wang and others, 1994), and, therefore, invoking a carbonatite source for REE's would also require evidence to indicate carbonatite magmatic activity lasting 150 million years. Bayan Obo, thus, is a prime and valuable example of the importance of paragenetic sequence, rather than mineral assemblages, in discerning the history and origin of a deposit, as well as the fact that associations of REE minerals, alkali amphiboles, and aegirine augite need not invoke a carbonatite source.

We were unable to obtain any information on the nature of the fluids from fluid inclusions. We found no fluid inclusions in any of the REE minerals we have studied. Fluid inclusions are most abundant in late-stage barite, which is essentially unrelated to specific episodes of REE mineralization. Minute fluid inclusions are also present in fluorite. Limited data on such inclusions were published by the Institute of Geochemistry (1988).

\section{AGE OR AGES OF EPISODES OF MINERALIZATION}

Bayan Obo is uniquely informative with respect to precise ages of REE mineralization and relative sequence of $\mathrm{Fe}$ and $\mathrm{Nb}$ mineralization. Episodes of REE mineralization began about $555 \mathrm{Ma}$ and lasted until about $400 \mathrm{Ma}$, a period of about 150 m.y. Fe mineralization began about $430 \mathrm{Ma}$ and lasted until after about $343 \mathrm{Ma}$. Bayan Obo is also unique in that the complex metamorphic and metasomatic histories can be documented by minimum mineral ages of 
the alkali amphiboles present, which cover a range from about $1.26 \mathrm{Ga}$ to about $300 \mathrm{Ma}$.

\section{LITHOLOGY AND AGE OF RESERVOIR ROCKS FAVORABLE FOR HOSTING THE ORES}

Although the $\mathrm{H} 8$ marble is not the only rock type that hosts Bayan Obo ores, it is clearly the dominant host rock. As marble, the reservoir host rock was particularly reactive with acid hydrothermal solutions, producing $\mathrm{CO}_{2}$ when the carbonate was dissolved by the acid solutions. Contemporaneously, the metals precipitated from the solution because of cooling and change of $\mathrm{pH}$ when the acid solution was neutralized. Clearly, carbonate host rocks rank as the most favorable reservoir host rocks for these ores.

Besides lithology, permeability of the host rock is also an important property to be considered. Textural evidence from Bayan Obo ores suggests that replacement of the host rock minerals was predominantly along grain boundaries and along microfractures. When extensive metasomatic replacement occurred, the host rock became completely replaced, as shown by some of the banded ores.

The age of the host rock is apparently also important. $\mathrm{H} 8$ is of Middle Proterozoic age, which existed prior to Caledonian episodes of mineralization. Any carbonate host rocks younger than the Caledonian would not have been mineralized. Hence, Proterozoic carbonate host rocks overlying Archean and Early Proterozoic source rocks, in conjunction with younger tectonic processes such as subduction or rifting, represent a good combination for the formation of these ore deposits.

\section{PRESERVATION OF THE ORES (CAP ROCKS)}

Another favorable condition for the formation of the Bayan Obo ores results from the presence of $\mathrm{H} 9$ biotite and albitized biotite schist, which is pelitic and less permeable than the underlying $\mathrm{H} 8$ host rocks. Although not perfectly impermeable, the $\mathrm{H} 9$ biotite schist acted as a cap rock and slowed down or stopped the escape of the incoming acid hydrothermal solutions. The ores precipitated by the solutions were therefore confined and preserved.

\section{BAYAN OBO AND THE PORPHYRY Cu-Mo ORE DEPOSITS OF PERU AND CHILE}

In order to gain further insight regarding giant and super giant ore deposits of hydrothermal origin, it may be useful to compare the Bayan Obo deposit with the Andean giant and super giant porphyry Cu-Mo ore deposits of South
America from Peru to Chile, although they are different ore types. Whether the key factor of giant ore deposits is the tectonic setting that sustains the long duration of mineralization should be carefully examined and tested.

Using the National Academy of Science size classification of ore deposits, Clark (1993) listed two Andean behemothian ( $>31$ million metric tons of $\mathrm{Cu}$ ) porphyry $\mathrm{Cu}$ ore deposits (El Tiniente and Chuquicomata) and seven super giant $(>10$ million metric tons of $\mathrm{Cu}$ ) porphyry $\mathrm{Cu}$ ore deposits (El Abra, Chuqui Norte, Los Pelambres-El Pachon, Rio Blanco-Los Bronces, La Escondita, Collahuasi-Rosario, and Mansa Mina). However, from the economic geology point of view, the best studied Andean porphyry $\mathrm{Cu}$-Mo deposit is the giant El Salvador, which is used as a standard for this type of ore deposit (Gustafson and Hunt, 1975). Of particular interest is the long period over which these deposits formed, which, on the basis of the ages of the porphyries, lasted approximately 95 m.y. (100-5 Ma) (Clark, 1993, fig. 10).

On the basis of the study of El Salvador, most investigators favor the interpretation that the subvolcanic porphyries with which these giant, super giant, and behemothian $\mathrm{Cu}-\mathrm{Mo}$ ore deposits are associated were related to the subduction of the Nazca (Farallon) oceanic plate (Clark, 1993, fig. 12). Hydrothermal solutions that deposited $\mathrm{Cu}$-sulfide veins were directly related to the mantle-derived melt that resulted in crystallization of the porphyry stocks close to the surface. Clark, using a study by Pardo-Casas and Molnar of 1987 (cited in Clark, 1993), summarized the timing of mineralization with respect to the displacement of the Nazca (Farallon) plate relative to South America as follows: (a) before and during early Eocene (62-52 Ma), porphyry copper emplacement in southern Peru and northernmost Chile; (b) before and during late Eocene and early Oligocene (42$31 \mathrm{Ma}$ ), emplacement in northern Chile; and (c) since 10.59 $\mathrm{Ma}$, emplacement of central Chilean porphyry $\mathrm{Cu}$ deposits. Thus, regionally the formation of Andean porphyry ore deposits migrated from north to south within about 50 million years.

The Andean porphyry Cu-Mo ore deposits are no doubt of hydrothermal origin because the principal ore metals occur mostly in two of three types of veins in the marginal zones of porphyries, according to Gustafson and Hunt (1975). The most important and the earliest $\mathrm{Cu}$ mineralization at El Salvador formed the A veins disseminated with chalcopyrite-bornite and locally, traces of molybdenite. B veins crosscut $A$ veins and were clearly later. $B$ veins characteristically contain molybdenite-chalcopyrite and traces of bornite in some of the veins. D veins, poor in quartz, crosscut both $\mathrm{A}$ and $\mathrm{B}$ veins and are the youngest veins. Pyrite is usually predominant in D veins, and chalcopyrite, bornite, enargite, tennantite, sphalerite, and galena are also present. Minor molybdenite and many other sulfides occur locally. 
Gustafson and Hunt (1975) concluded that, based on isotopic age data, the period of mineralization in the veins and associated porphyry is essentially less than a million years, not resolvable by the K-Ar method of dating available at the time of their study. Redating the veins and porphyries using the ${ }^{40} \mathrm{Ar} /{ }^{39} \mathrm{Ar}$ and $\mathrm{Re}-\mathrm{Os}$ methods may provide additional information about the mineralization history at El Salvador. The porphyry stocks that intruded the volcanic-covered terrain required time to cool before fracturing could occur to provide openings for the deposition of $\mathrm{Cu}$ ore in veins. If one assumes the cooling rate of a porphyry stock to be $50-10^{\circ} \mathrm{C} / \mathrm{m}$.y. and if the original meltmush was at a temperature above $800^{\circ} \mathrm{C}$, it would require several million years to cool before fracturing could occur. Therefore, dating the porphyries with the ${ }^{40} \mathrm{Ar} /{ }^{39} \mathrm{Ar}$ method or with $\mathrm{Rb} / \mathrm{Sr}$ mineral isochrons and dating the age of the veins directly using the $\mathrm{Re}-\mathrm{Os}$ method on $\mathrm{Cu}$-sulfides and molybdenite may provide new insights about the duration of mineralization at El Salvador.

The basic question of interest is whether the hydrothermal solutions necessarily are related to the generation of the porphyry melt by subduction of the Nazca (Farallon) plate. Subduction-related heating could easily have generated the porphyry melt and the hydrothermal solutions enriched in sulfides at essentially the same time, or the hydrothermal solutions may have been generated several million years later than and independent of the melt.

Bayan Obo appears to have some aspects in common with the porphyry Cu-Mo ore deposits of the Andes: (1) they both lie along the margin of a craton affected by subduction of an oceanic plate; (2) they both have a long duration of formation of ore, covering a span of more than $\mathbf{5 0}$ m.y.; and (3) they are both of hydrothermal origin. The principal differences are (1) they are different deposit types;
(2) Bayan Obo episodes of mineralization were restricted to a single deposit, whereas the Andean porphyry $\mathrm{Cu}-\mathrm{Mo}$ deposits, representing a span of more than 90 m.y., consist of many separate giant and super giant deposits of similar types; and (3) evidence for Caledonian subduction in the Bayan Obo area is restricted to an $850-\mathrm{km}$ trace, whereas according to Clark (1993), the location of subduction of the Nazca (Farallon) plate under the Andean crust moved from north under Peru, to south under southern Chile, to east under northern Chile. This movement would account for the sequence and locations of the porphyry $\mathrm{Cu}-\mathrm{Mo}$ deposits of the Andean belt.

In the case of Bayan Obo, there is no evidence of any igneous melt related to the hydrothermal solutions that deposited the REE's, Fe, and $\mathrm{Nb}$ of that deposit. The key lies in the source area, where the subduction-related heat generation caused scavenging of ore metals from the lower crust and enrichment of ore metals in the hydrothermal solutions. Within the mine region $(16 \mathrm{~km}$ by $2-3 \mathrm{~km})$ at Bayan Obo, multiple episodes of REE mineralization, hypothetically generated by Caledonian subduction, lasted more than 150 m.y. With regard to the Andean porphyry $\mathrm{Cu}$-Mo deposits, episodic subduction (from before $60 \mathrm{Ma}$ to about $5 \mathrm{Ma}$ ) activated the mantle-crust source region to produce the world's largest porphyry Cu-Mo ore deposits.

One may also wish to compare Bayan Obo and the Andean porphyry $\mathrm{Cu}-\mathrm{Mo}$ ore deposits with the $\mathrm{Sn}$ granite ore deposits of Bolivia, central South America, or other areas of the world, to see if activities in certain tectonic settings, such as rifting or subduction, can cause repeated generation of either ore-related igneous melts or ore-related hydrothermal solutions. Similarities of types of ore deposits are not necessarily required as a key to the origin of giant ore deposits in favorable tectonic settings. 


\section{PART IV. SUMMARY AND CONCLUSIONS AND REFERENCES}

\section{SUMMARY AND CONCLUSIONS}

In part I, we described the characteristics and paragenesis of the giant Bayan Obo REE-Fe-Nb ore deposit:

1. Bayan Obo is on the northern edge of the North China craton, near the suture of Caledonian subduction of the Mongolian plate beneath the craton.

2. The host $\mathrm{H} 8$ marble and quartzite are sedimentary rocks that were metamorphosed prior to mineralization.

3. The deposit is mineralogically very complex, and ore classification is based on host rocks, ore type (disseminated, banded, or massive), and mineral assemblages. The Main and the East Orebodies are surrounded by disseminated ores and have intermediate zones of banded ores and massive $\mathrm{Fe}$ cores.

4. Metamorphic and replacement textures provide evidence for the epigenetic, hydrothermal, metasomatic origin of the Bayan Obo ore deposit.

5. Precise ages of episodes of REE mineralization, supported by chemical compositions of various generations of monazites and bastnaesites, indicate that the episodes of REE mineralization lasted from about 555 to $395 \mathrm{Ma}$, a duration of about 150 m.y.

6. Textural relations among the three main Fe ore minerals, precise ages of REE minerals, and minimum ages of associated alkali amphiboles of metasomatic origin indicate that most Fe mineralization occurred between about 430 and $390 \mathrm{Ma}$. Most $\mathrm{Nb}$ mineralization resulted in disseminated ores associated with the West Orebodies.

7. Textural relations, mineral ages, and chemical composition of various generations of REE's and alkali amphiboles indicate three periods of regional metamorphism: Late Proterozoic, early Paleozoic (Caledonian), and late Paleozoic (Hercynian). These data also provide evidence of hydrothermal activities ranging from $1.26 \mathrm{Ga}$ to beyond $343 \mathrm{Ma}$.

8. The complex history of the Bayan Obo deposit, from the deposition of the $\mathrm{H} 8$ carbonates $(>1.26 \mathrm{Ga}$ ) to the end of Hercynian (Permian) granitic intrusion (about $260 \mathrm{Ma}$ ), is illustrated by the generalized mineral paragenetic sequence (table 13).

In part II, we described and discussed evidence for Caledonian subduction, origin of the Caledonian Hejao granitic rocks $50 \mathrm{~km}$ south of the Bayan Obo mine region, and the probability that Caledonian subduction and regional metamorphism provided a repeated activation mechanism and heat source that helped to generate not only REE- and
Fe-rich hydrothermal ore fluids of Bayan Obo, but also the A-type and S-type anorogenic Hejao granitic rocks.

In part III, we discussed the giant Bayan Obo REE-Fe$\mathrm{Nb}$ ore deposit as a cornerstone example of a giant ore deposit in terms of the following parameters: (1) the Early Proterozoic and crustal sources of REE's, $\mathrm{Fe}$, and $\mathrm{Nb}$ on the basis of (a) occurrence of large amounts of LREE-rich allanites in Early Proterozoic gneisses and pegmatites, and (b) isotopic indicators of large negative $\varepsilon_{\mathrm{Nd}}$ values; (2) the favorable tectonic setting for mineralization during the Caledonian orogeny; (3) the probable mechanism for concentrating ore metals in the hydrothermal solutions in source reservoirs; (4) the geochemical evolution, based on the mineral paragenetic sequence; (5) the mode of transport of REE complexes from the lower sialic crust to the $\mathrm{H} 8$ unit of the Bayan Obo Group; (6) the ages of episodes of mineralization; (7) the Middle Proterozoic H8 marble as the favorable reservoir rocks hosting the Bayan Obo ores; and (8) the less permeable $\mathrm{H} 9$ pelitic biotite and albitized biotite schist as cap rocks that probably preserved the ore within the upper part of the $\mathrm{H} 8$ marble host rocks.

Bayan Obo and the Andean giant and super giant porphyry Cu-Mo ore deposits were both formed in subduction zone environments over long periods of time. Although the ore types differ, comparison of these deposits may help to increase our understanding of the paragenesis of giant polymetallic deposits.

\section{REFERENCES CITED}

Bai Ge and Yuan Zhongxin, 1985, Carbonatites and related mineral resources: Chinese Academy of Geological Sciences, Bulletin of the Institute of Mineral Deposits, no. 13, p. $107-$ 140. [In Chinese, English abstract, p. 189-192.]

Chao, E.C.T., Back, J.M., Minkin, J.A., and Ren Yingchen, 1992, Host-rock controlled epigenetic, hydrothermal metasomatic origin of the Bayan Obo REE-Fe-Nb ore deposit, Inner Mongolia, P.R.C.: Applied Geochemistry, v. 7 p. $443-458$.

Chao, E.C.T., Tatsumoto Mistunobu, Erickson, R.L., Minkin, J.A., Back, J.M., Buden, R.V., Okita, P.M., Hou Zonglin, Meng Qingrun, Ren Yingchen, Sun Weijun, McKee, E.H., Turrin, Brent, Wang Junwen, Li Xibin, and Edwards, C.A., 1990, Origin and ages of mineralization of Bayan Obo, the world's largest rare earth ore deposit, Inner Mongolia, China: U.S. Geological Survey Open-File Report 90-538, 11 p.

Chao, E.C.T., Tatsumoto, Mistunobu, and McKee, E.H., 1995, Caledonian subduction, repeated activation, and multiple episodes of mineralization of the Bayan Obo REE-Fe-Nb ore 
deposit, Inner Mongolia, China: Metallogeny and Global Tectonics, v. 5.

Chao, E.C.T., Tatsumoto, Mistunobu, Minkin, J.A., Back, J.M., McKee, E.H., and Ren Yingchen, 1993, Multiple lines of evidence for establishing the mineral paragenetic sequence of the Bayan Obo rare earth ore deposit of Inner Mongolia, China, in Proceedings of the Eighth Quadrennial IAGOD Symposium, August 12-18, 1990, Ottawa, Canada: Stuttgart, E. Schweizerbart'sche Verlagsbuchhandlung, p. 55-73.

Chao, E.C.T., and Xie Xiande, 1990, Mineralogical approaches to geological investigations: Beijing, China, Science Press, $338 \mathrm{p}$.

Chen, J.R., Chao, E.C.T., Back, J.M., Minkin, J.A., Rivers, M.L., Sutton, S.R., Cygan, G.L., Grossman, J.N., and Reed, M.J., 1993, Rare earth element concentrations in geological and synthetic samples using synchrotron $\mathrm{X}$-ray fluorescence analysis: Nuclear Instruments and Methods in Physics Research B75, p. 576-581.

Chen Shuzeng, Xu Xinji, Wang Yangjie, and Zhang Peishan, 1990, REE-iron deposit, skarn minerals, and gold deposit in Bayan Obo, Inner Mongolia Autonomous Region, China, in Field trip guidebook T002, 15th IMA annual meeting, July 1990, Beijing: 10 p.

Clark, A.H., 1993, Are outsized porphyry copper deposits either anatomically or environmentally distinctive?, in Whiting, B.H., Mason, R., and Hodgson, C.J., eds., Proceedings of Giant Ore Deposits Workshop, Kingston, Canada, May 1113, 1992: Kingston, Ontario, QMinEx Associates and Queen's University, p. 525-607.

Conrad, J.E., and McKee, E.H., $1992,{ }^{40} \mathrm{Ar} /{ }^{39} \mathrm{Ar}$ dating of vein amphibole from the Bayan Obo iron-rare earth element-niobium deposit, Inner Mongolia, China-Constraints on mineralization and deposition of the Bayan Obo Group: Economic Geology, v. 87, p. 185-188.

Conrad, J.E., McKee, E.H., and Turrin, B.D., 1991, Laser-microprobe single-grain ${ }^{40} \mathrm{Ar} /{ }^{39} \mathrm{Ar}$ age-spectrum analysis of riebeckite from Bayan Obo, China-Implications for dating disturbed minerals [abs.]: Geological Society of America Abstracts with Programs, v. 23, no. 2, p. 15.

Doe, Bruce, 1993, The importance of source rocks in formation of metallic-sulfide ore deposits, chapter AA in Scott, R.W., Jr., Detra, P.S., and Berger, B.R., eds., Advances related to United States and international mineral resources-Developing frameworks and exploration technologies: U.S. Geological Survey Bulletin 2039, p. 275-277.

Drew, L.J., Meng Qingrun, and Sun Weijun, 1990, The Bayan Obo iron-rare earth-niobium deposits, Inner Mongolia, China: Lithos, v. 26, p. 43-65.

Eby, G.N., 1990, The A-type granitoids-A review of their occurrence and chemical characteristics and speculations on their petrogenesis: Lithos, v. 26, p. 115-134.

Gustafson, L.B., and Hunt, J.P., 1975, The porphyry copper deposit at El Salvador, Chile: Economic Geology, v. 70, no. 5, p. 857-912.

Harland, W.F., Armstrong, R.L., Cox, A.V., Craig, L.E., Smith, A.G., and Smith, D.G., 1990, A geologic time scale-1989: New York, Cambridge University Press, 263 p.

Harrison, T.M., 1981, Diffusion of ${ }^{40} \mathrm{Ar}$ in hornblende: Contributions to Mineralogy and Petrology, v. 78, p. 324-331.
Harrison, T.M., Duncan, I., and McDougall, I., 1985, Diffusion of ${ }^{40} \mathrm{Ar}$ in biotite, temperature, pressure, and compositional effects: Geochimica et Cosmochimica Acta, v. 49, p. 24612468.

Hemley, J.J., Cygan, G.L., Fein, J.B., Robinson, G.R., and d'Angelo, W.M., 1992, Hydrothermal ore-forming processes in the light of studies in rock-buffered systems-I. Iron-copper-zinc-lead sulfide solubility relations: Economic Geology, v. 87, p. 1-22.

Humphris, S.E., 1984, The mobility of the rare earth elements in the crust, chap. 9 in Henderson, P., ed., Rare earth element geochemistry: New York, Elsevier, p. 317-342.

Institute of Geochemistry, Academia Sinica, 1988, The geochemistry of the Bayan Obo ore deposit: Beijing, China, Science Press, 554 p. [In Chinese.]

Jackson, L.L., Brown, F.W., and Neil, S.T., 1987, Major and minor elements requiring individual determination, classical whole rock analysis, and rapid rock analysis, chap. $\mathrm{G}$ in Baedecker, P.A., ed., Methods for geochemical analysis: U.S. Geological Survey Bulletin 1770, p. G1-G23.

Le Bas, M.J., Keller, J., Tao Kejie, Wall, F., Williams, C.T., and Zhang Peishan, 1992, Carbonatite dykes at Bayan Obo, Inner Mongolia, China: Mineralogy and Petrology, v. 45, no. 3, p. 195-228.

Li Qin and Zhang Jiangman, 1993, Dispute of the occurrence of Qinghezhen small shelly fauna of northern Hopei: Regional Geology of China, no. 4, p. 364-370. [In Chinese.]

Lichte, F.E., Golightly, D.W., and Lamothe, P.J., 1987, Inductively coupled plasma-atomic emission spectrometry, chap. B in Baedecker, P.A., ed., Methods for geochemical analysis: U.S. Geological Survey Bulletin 1770, p. B1-B10.

Liu Tiegeng, 1986, A discussion on the genesis of dolomite in Bayan Obo, Inner Mongolia-with emphasis on the composition of oxygen and carbon isotopes: Geology Review, v. 32, no. 2, p. 150-154. [In Chinese, English abstract.]

Liu Xiaoliang and Wang Dongfang, 1990, A new fauna-Qinghezhen fauna-from the northem margin of the North China Platform: Acta Geologica Sinica, v. 3, no. 4, p. 443-458.

Meng Qingrun, 1982, The genesis of the host rock dolomite of the Bayan Obo iron ore deposit and the analysis of its sedimentary environment: Geology Review, v. 24 , no. 6, p. 481-489. [In Chinese.]

Meng Qingrun and Drew, L.J., 1992, Study on oxygen and carbon isotopes and the implication for genesis of Bayan Obo orebearing $\mathrm{H} 8$ dolomite: Contributions to Geology and Mineral Resources Research, v. 7, no. 2, p. 46-54.

Parrish, R.R., 1990, U-Pb dating of monazite and its application to geological problems: Canadian Journal of Earth Sciences, v. 27, p. 1431-1450.

Qiao Xiufu, Yao Peiyi, Wang Chengshu, Tan Lin, Zhu Shenyu, Zhou Shengde, and Zhang Yuqing, 1991, Sequence stratigraphy and tectonic environment of the Chartai Group of Inner Mongolia: Acta Geologica Sinica, v. 65, no. 1, p. 1-14.

Taggart, J.E., Jr., Lindsay, J.R., Scott, B.A., Vivit, D.V., Bartel, A.J., and Stewart, K.C., 1987, Analysis of geologic materials by wavelength-dispersive X-ray fluorescence spectrometry, chap. E in Baedecker, P.A., ed., Methods for geochemical analysis: U.S. Geological Survey Bulletin 1770, p. E1-E19. 
Tang Kedong and Yan Zhuyun, 1993, Regional metamorphism and tectonic evolution of the Inner Mongolian suture zone: Journal of Metamorphic Geology, v. 11, no. 4, p. 511-522.

Wang Dongfang, Chen Congyun, and Yang Sen, 1990, Discovery of the Early Cambrian giant fossil belt, and the disintegration of the Inner Mongolian Axis: Kexue Tungbao, Journal of Science, no. 5, p. 370-373. [In Chinese.]

Wang Dongfang, Chen Congyun, Yang Sen, Liu Xiaoliang, Zhang Jongfei, and Yang Xuezeng, 1992, The continental geology in northern margin of Sino-Korean platform: Beijing, Seismological Press, 356 p. [In Chinese, English summary, p. 357364.]

Wang Hungzhen, chief compiler, 1985, Atlas of the paleogeography of China: Beijing Institute of Geology, Chinese Academy of Geological Sciences, Wuhan College of Geology, 85 p. [In Chinese, English summary, 28 p.]

Wang Junwen, Tatsumoto, Mistunobu, Li Xibin, Premo, W.R., and Chao, E.C.T., 1994, A precise ${ }^{232} \mathrm{Th} /{ }^{208} \mathrm{~Pb}$ chronology of finegrained monazite-Age of the Bayan Obo REE-Fe-Nb ore deposit, China: Geochimica et Cosmochimica Acta, v. 58, no. 15, p. 3155-3169.

Wang Quan, Liu Xueya, and Li Jinyi, 1991, Paleoplate tectonics in Nei Monggol of China: Bulletin of the Chinese Academy of Geological Sciences, no. 22, p. 1-19.

Whiting, B.H., Mason, R., and Hodgson, C.J., eds., 1992, Proceedings of Giant Ore Deposits Workshop, Kingston, Canada, May 11-13, 1992: Kingston, Ontario, QMinEx Associates and Queen's University, $607 \mathrm{p}$.

Zhang Peishan and Tao Kejie, 1986, Bayan Obo mineralogy: Beijing, China, Science Press, p. 1-182. [In Chinese, English summary, p. 199-208.]

Zhang Yunping, 1994, Evidence for non-existence of the Qinghezhen fossil fauna: Geological Science, v. 29, no. 2, p. 175185. [In Chinese.]

Zhao Chunjing and Li Zhitong, 1987, The granites of central New Mongol in Paleozoic plate tectonics-Collection of papers on plate tectonics of North China: Shengyang, China, Shengyang Institute of Geology and Mineral Resources, Geologic Press, v. 2, p. 80-100. [In Chinese, English abstract.] 



\section{SELECTED SERIES OF U.S. GEOLOGICAL SURVEY PUBLICATIONS}

\section{BOOKS AND OTHER PUBLICATIONS}

Professional Papers report scientific data and interpretations of lasting scientific interest that cover all facets of USGS investigations and research.

Bulletins contain significant data and interpretations that are of lasting scientific interest but are generally more limited in scope or geographic coverage than Professional Papers.

Water-Supply Papers are comprehensive reports that present significant interpretive results of hydrologic investigations of wide interest to professional geologists, hydrologists, and engineers. The series covers investigations in all phases of hydrology, including hydrogeology, availability of water, quality of water, and use of water.

Circulars are reports of programmatic or scientific information of an ephemeral nature; many present important scientific information of wide popular interest. Circulars are distributed at no cost to the public.

Fact Sheets communicate a wide variety of timely information on USGS programs, projects, and research. They commonly address issues of public interest. Fact Sheets generally are two or four pages long and are distributed at no cost to the public.

Reports in the Digital Data Series (DDS) distribute large amounts of data through digital media, including compact disc-read-only memory (CD-ROM). They are high-quality, interpretive publications designed as self-contained packages for viewing and interpreting data and typically contain data sets, software to view the data, and explanatory text.

Water-Resources Investigations Reports are papers of an interpretive nature made available to the public outside the formal USGS publications series. Copies are produced on request (unlike formal USGS publications) and are also available for public inspection at depositories indicated in USGS catalogs.

Open-File Reports can consist of basic data, preliminary reports, and a wide range of scientific documents on USGS investigations. Open-File Reports are designed for fast release and are available for public consultation at depositories.

\section{MAPS}

Geologic Quadrangle Maps (GQ's) are multicolor geologic maps on topographic bases in 7.5- or 15-minute quadrangle formats (scales mainly $1: 24,000$ or $1: 62,500$ ) showing bedrock, surficial, or engineering geology. Maps generally include brief texts; some maps include structure and columnar sections only.

Geophysical Investigations Maps (GP's) are on topographic or planimetric bases at various scales. They show results of geophysical investigations using gravity, magnetic, seismic, or radioactivity surveys, which provide data on subsurface structures that are of economic or geologic significance.
Miscellaneous Investigations Series Maps or Geologic Investigations Series (I's) are on planimetric or topographic bases at various scales; they present a wide variety of format and subject matter. The series also includes 7.5-minute quadrangle photogeologic maps on planimetric bases and planetary maps.

\section{INFORMATION PERIODICALS}

Metal Industry Indicators (MII's) is a free monthly newsletter that analyzes and forecasts the economic health of five metal industries with composite leading and coincident indexes: primary metals, steel, copper, primary and secondary aluminum, and aluminum mill products.

Mineral Industry Surveys (MIS's) are free periodic statistical and economic reports designed to provide timely statistical data on production, distribution, stocks, and consumption of significant mineral commodities. The surveys are issued monthly, quarterly, annually, or at other regular intervals, depending on the need for current data. The MIS's are published by commodity as well as by State. A series of international MIS's is also available.

Published on an annual basis, Mineral Commodity Summaries is the earliest Government publication to furnish estimates covering nonfuel mineral industry data. Data sheets contain information on the domestic industry structure, Government programs, tariffs, and 5-year salient statistics for more than 90 individual minerals and materials.

The Minerals Yearbook discusses the performance of the worldwide minerals and materials industry during a calendar year, and it provides background information to assist in interpreting that performance. The Minerals Yearbook consists of three volumes. Volume I, Metals and Minerals, contains chapters about virtually all metallic and industrial mineral commodities important to the U.S. economy. Volume II, Area Reports: Domestic, contains a chapter on the minerals industry of each of the 50 States and Puerto Rico and the Administered Islands. Volume III, Area Reports: International, is published as four separate reports. These reports collectively contain the latest available mineral data on more than 190 foreign countries and discuss the importance of minerals to the economies of these nations and the United States.

\section{PERMANENT CATALOGS}

"Publications of the U.S. Geological Survey, 1879-1961" and "Publications of the U.S. Geological Survey, 1962-1970" are available in paperback book form and as a set of microfiche.

"Publications of the U.S. Geological Survey, 1971-1981" is available in paperback book form (two volumes, publications listing and index) and as a set of microfiche.

Annual supplements for 1982, 1983, 1984, 1985, 1986, and subsequent years are available in paperback book form. 


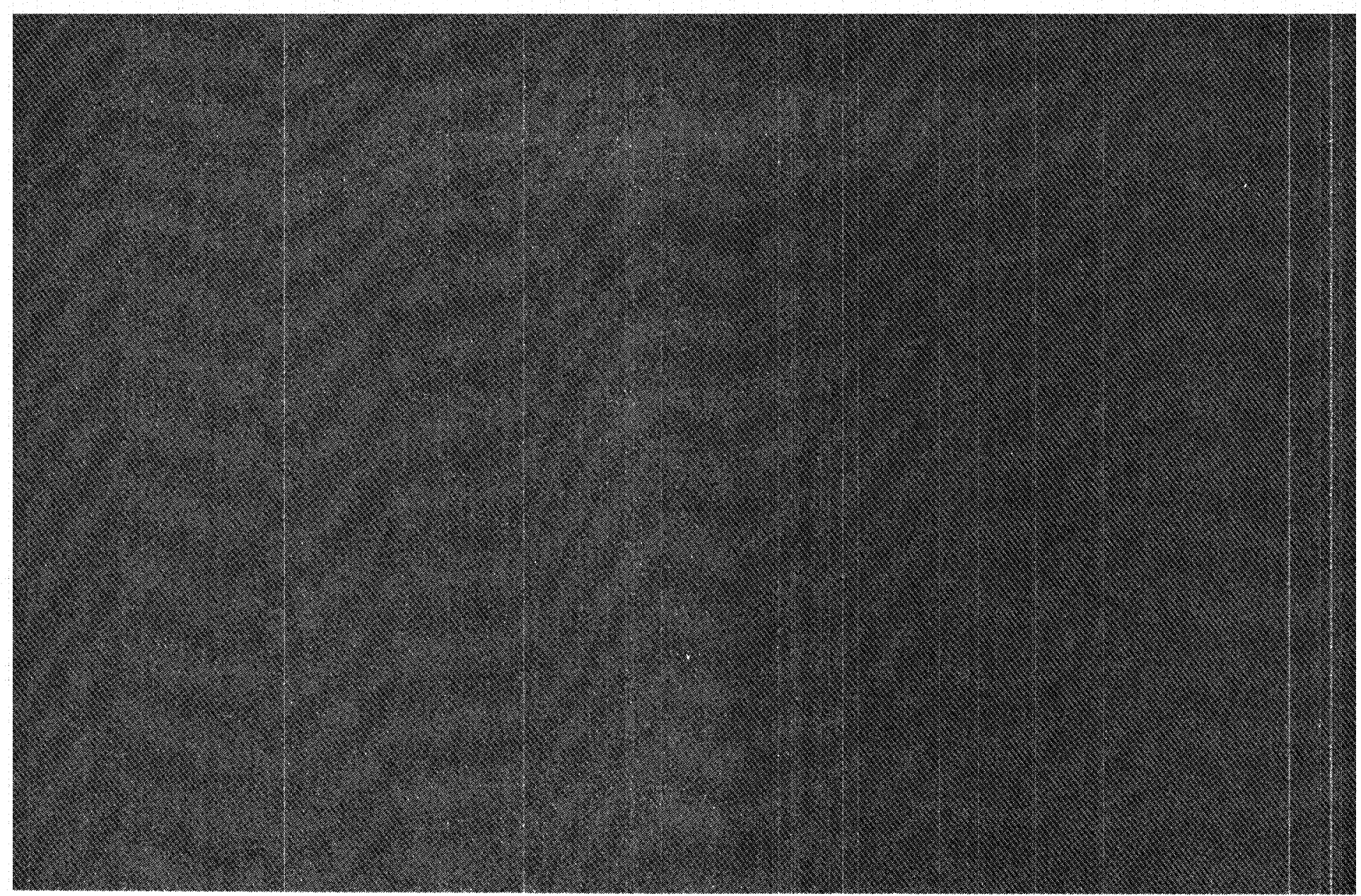

ISBN 0-607-8B143-?

|||||||||||||||||||| |||

q $1780607 \|_{881431}$ 